$$
\begin{gathered}
\text { RECEIVEC } \\
\text { DEC } 04998 \\
\text { OSTI }
\end{gathered}
$$

ORNL/TM-13652

\section{Grout and Glass Performance in Support of Stabilization/Solidification of the MVST Tank Sludges}

WMWAEB AND OPERATED BY

LOCKHEED WARTN ENERGY RESEARCH CORPORATION FOR THE UITED STATLS. DEPARTUENT OF ENEREY

R. D. Spence

T. M. Gilliam 
This report has been reproduced from the best available copy.

Reports are available to the public from the following source.

National Technical Information Service

5285 Port Royal Road

Springfield, VA 22161

Telephone 703-605-6000 (1-800-553-6847)

TDD 703-487-4639

Fax 703-605-6900

E-mail orders@ ntis.fedworld.gov

Web site http://www.ntis.gov/ordering.htm

Reports are available to U.S. Department of Energy (DOE) employees, DOE contractors, Energy Technology Data Exchange (ETDE) representatives, and International Nuclear Information System (INIS) representatives from the following source.

Office of Scientific and Technical Information

P.O. Box 62

Oak Ridge, TN 37831

Telephone 423-576-8401

Fax 423-576-5728

E-mail reports@adonis.osti.gov

Web site http://www.osti.gov/products/sources.html

Reports produced after January 1, 1996, are generally available via the DOE Information Bridge.

Web site http://www.doe.gov/bridge 


\section{DISCLAIMER}

This report was prepared as an account of work sponsored by an agency of the United States Government. Neither the United States Government nor any agency thereof, nor any of their employees, make any warranty, express or implied, or assumes any legal liability or responsibility for the accuracy, completeness, or usefulness of any information, apparatus, product, or process disclosed, or represents that its use would not infringe privately owned rights. Reference herein to any specific commercial product, process, or service by trade name, trademark, manufacturer, or otherwise does not necessarily constitute or imply its endorsement, recommendation, or favoring by the United States Government or any agency thereof. The views and opinions of authors expressed herein do not necessarily state or reflect those of the United States Government or any agency thereof. 


\section{DISCLAIMER}

Portions of this document may be illegible in electronic image products. Images are produced from the best available original document. 
Chemical Technology Division

\section{GROUT AND GLASS PERFORMANCE IN SUPPORT OF STABILIZATION/SOLIDIFICATION \\ OF THE MVST TANK SLUDGES}

R. D. Spence and T. M. Gilliam

Date Published: November 1998

\section{Prepared by}

OAK RIDGE NATIONAL LABORATORY

Oak Ridge, Tennessee 37831-6285

managed by

LOCKHEED MARTIN ENERGY RESEARCH CORP.

for the

U.S. DEPARTMENT OF ENERGY

under contract DE-AC05-96OR22464 

LIST OF FIGURES $\ldots \ldots \ldots \ldots \ldots \ldots \ldots \ldots \ldots \ldots \ldots \ldots \ldots \ldots \ldots \ldots \ldots \ldots$

EXECUTTVE SUMMARY $\ldots \ldots \ldots \ldots \ldots \ldots \ldots \ldots \ldots \ldots \ldots \ldots \ldots \ldots$ ix

1. INTRODUCTION $\ldots \ldots \ldots \ldots \ldots \ldots \ldots \ldots \ldots \ldots \ldots \ldots \ldots \ldots \ldots \ldots \ldots$

2. OBJECTIVE $\ldots \ldots \ldots \ldots \ldots \ldots \ldots \ldots \ldots \ldots \ldots \ldots \ldots \ldots \ldots \ldots \ldots \ldots$

3. SURROGATES $\ldots \ldots \ldots \ldots \ldots \ldots \ldots \ldots \ldots \ldots \ldots \ldots \ldots \ldots \ldots \ldots \ldots \ldots$

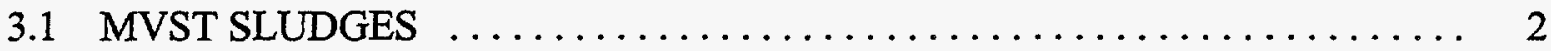

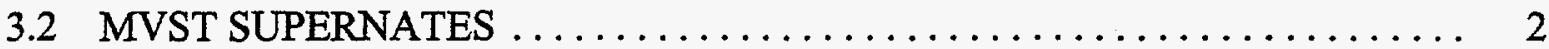

4. GROUT $\quad \ldots \ldots \ldots \ldots \ldots \ldots \ldots \ldots \ldots \ldots \ldots \ldots \ldots \ldots \ldots \ldots \ldots \ldots$

4.1 SELECTION OF THE DRY BLEND ADDITIVES FOR FURTHER

EVALUATION ................................. 3

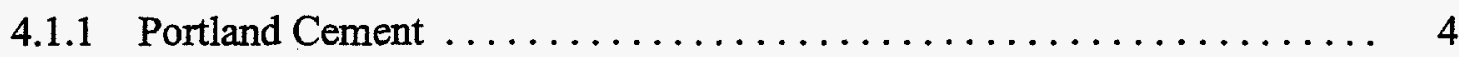

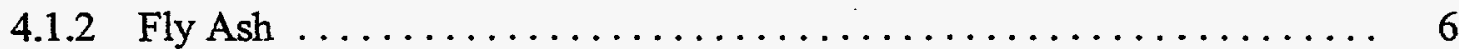

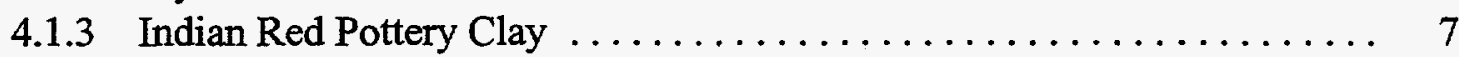

4.1.4 Ground Granulated Blast Furnace Slag $\ldots \ldots \ldots \ldots \ldots \ldots \ldots \ldots \ldots$

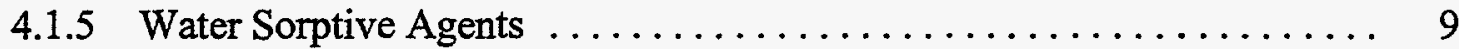

4.2 SELECTING GROUT COMPOSITION FOR EVALUATION $\ldots \ldots \ldots \ldots \ldots$

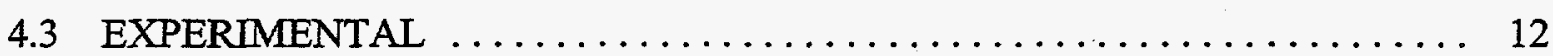

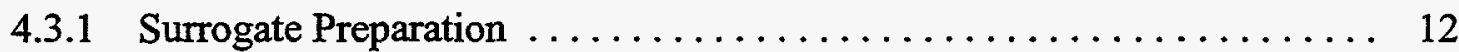

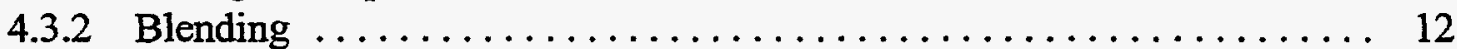

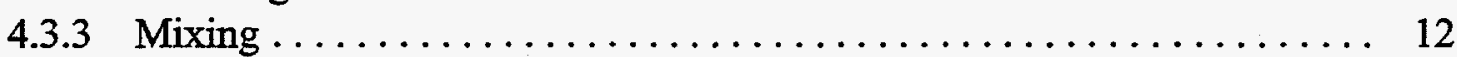

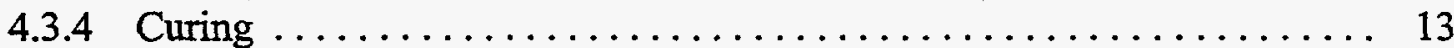

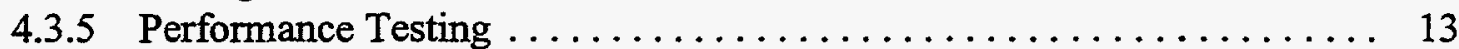

4.4 RESULTS AND DISCUSSION $\ldots \ldots \ldots \ldots \ldots \ldots \ldots \ldots \ldots \ldots \ldots \ldots \ldots \ldots \ldots \ldots$

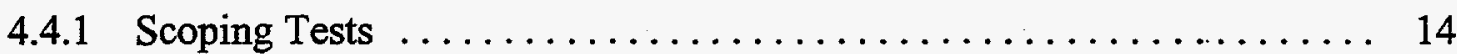

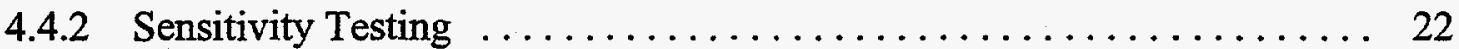

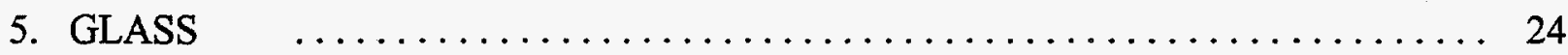

5.1 SELECTION OF THE GLASS FORMING SYSTEM FOR FURTHER

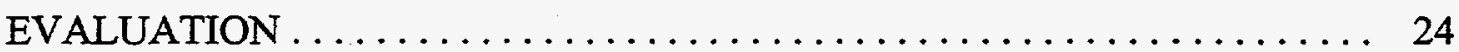

5.2 SELECTING GLASS COMPOSITION REGION FOR EVALUATION . . . . . 25 


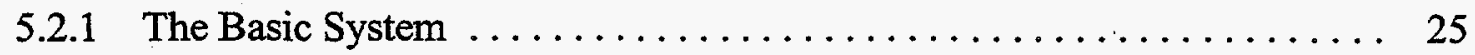

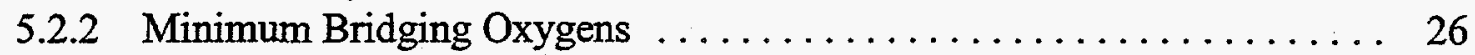

5.2.3 Waste Composition on an Oxide Basis . . . . . . . . . . . . . 27

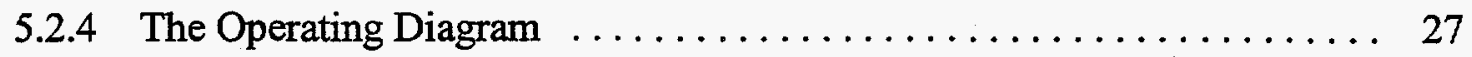

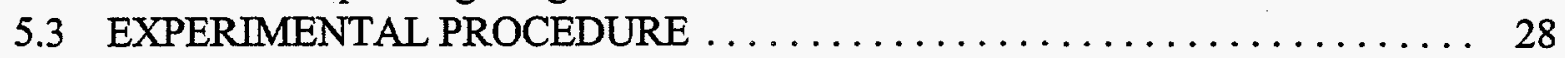

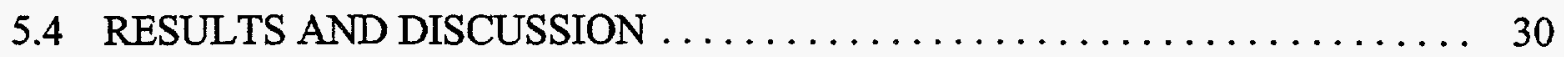

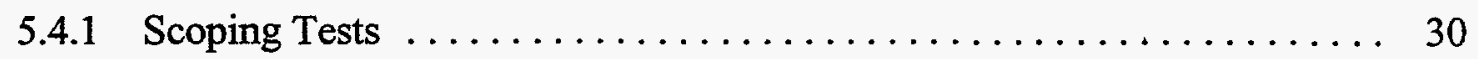

5.4.2 Appearance of Glass Above the Melt Line . ............... 33

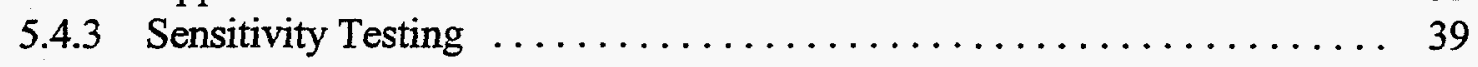

6. SUMMARY AND CONCLUSIONS $\ldots \ldots \ldots \ldots \ldots \ldots \ldots \ldots \ldots \ldots \ldots \ldots \ldots \ldots$

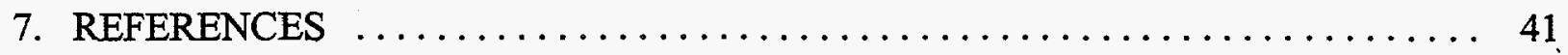




\section{LIST OF TABLES}

1 Composition of the MVST sludges $\ldots \ldots \ldots \ldots \ldots \ldots \ldots \ldots \ldots \ldots, \ldots \ldots \ldots$

2 Target composition for the surrogate MVST sludge $\ldots \ldots \ldots \ldots \ldots \ldots \ldots 49$

3 Composition of the MVST supernates ...................... 50

4 Target composition for the surrogate MVST supernate $\ldots \ldots \ldots \ldots \ldots \ldots .52$

5 Ionic concentrations for the surrogate MVST supernate in Table $4 \ldots \ldots \ldots \ldots 53$

$6 \quad$ Composition of the grouts tested during the scoping tests $\ldots \ldots \ldots \ldots \ldots . \ldots 54$

7 The measured grout densities and grout volume relative to the surrogate MVST wet sludge volume for the scoping tests $\ldots \ldots \ldots \ldots \ldots \ldots \ldots \ldots \ldots .65$

8 Free water and penetration resistance measured for the scoping test grouts ..... 56

9 Concentrations of the RCRA metals and uranium in the TCLP extract of the surrogate MVST sludge ............................ 57

10 Concentrations of the RCRA metals and uranium in the TCLP extract of the grouts from the scoping tests $\ldots \ldots \ldots \ldots \ldots \ldots \ldots \ldots \ldots \ldots \ldots \ldots$

11 Grout composition for sensitivity testing of grouting the surrogate MVST sludge

12 Surrogate MVST sludge composition used in sensitivity testing

13 The measured grout densities and grout volume relative to the surrogate MVST wet sludge volume for the sensitivity testing grouts $\ldots \ldots \ldots \ldots \ldots \ldots \ldots 60$

14 Free waters measured for the sensitivity testing grouts .............. 61

15 Unconfined compressive strengths measured for the sensitivity testing grouts ...66 62

16 TCLP extract concentrations measured for the sensitivity testing grouts ......66 63

17 The measured leachability indexes of ${ }^{85} \mathrm{Sr}$ and ${ }^{137} \mathrm{Cs}$ for the sensitivity testing

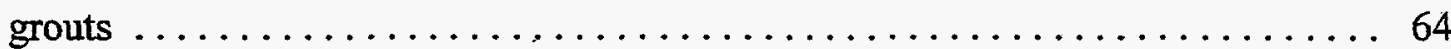

18 Calculated surrogate composition on an oxide basis $\ldots \ldots \ldots \ldots \ldots \ldots \ldots \ldots 6$

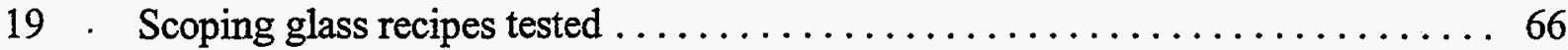

20 TCLP values $(\mathrm{mg} / \mathrm{L})$ from scoping glasses prepared with MVST surrogate . . . . 67

$21 \quad$ Feed and glass compositions for the MVST glass sensitivity testing $\ldots \ldots \ldots \ldots 68$

22. $\mathrm{Fe}^{2+} / \mathrm{Fe}^{3+}$ redox couple determinations for glass products of sensitivity testing ...6 69

23 Composition of the surrogate MVST sludge solids used in the glass sensitivity

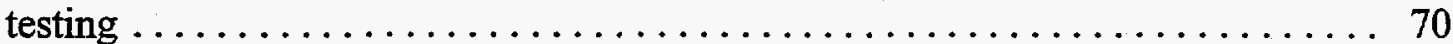

24 Glass bulk density and ratio of glass volume to wet sludge for the sensitivity

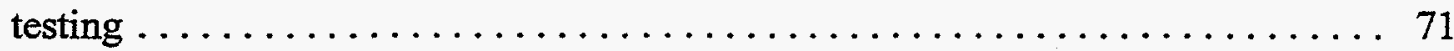

25 Total dissolution analysis of glasses from sensitivity testing and leachate analysis with estimated leachability indexes for cesium and strontium $\ldots \ldots \ldots \ldots .72$ 

LIST OF FIGURES

Figure

Page

1 Grout density as a function of the water-to-solids ratio (W/S) $\ldots \ldots \ldots \ldots$

2 Volume ratio of grout-to-wet sludge as a function of the wet sludge loading . . . . 16

3 Free water as a function of the water-to-solids ratio (W/S) without water-sorptive

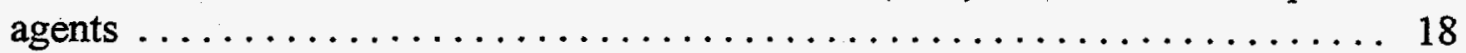

4 Free water as a function of the percentage of water sorptive agent in the dry

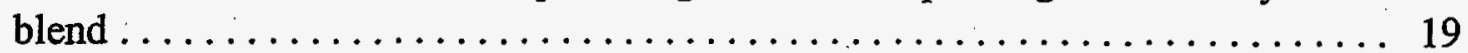

5 Free water as a function of sludge loading for the selected dry blend . . . . . . 20

$6 \quad$ Penetration resistance as a function of sludge loading for the selected dry blend .. 21

7 Uranium concentration in TCLP extracts of the scoping test grouts

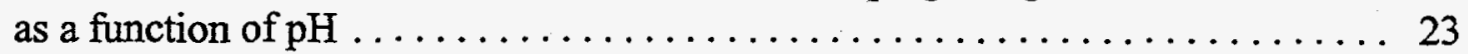

8 Calculated region of acceptable glass compositions $\ldots \ldots \ldots \ldots \ldots \ldots \ldots \ldots$

9 Glass compositions presented on ternary diagram $\ldots \ldots \ldots \ldots \ldots \ldots \ldots \ldots \ldots$

10 Typical XRD pattern from amorphous glass $\ldots \ldots \ldots \ldots \ldots \ldots \ldots \ldots \ldots$

11 Typical XRD diffraction pattern from glass that is slightly crystalline . . . . . 35

12 Typical XRD diffraction pattern for glass that is strongly crystalline . . . . . 36 



\section{EXECUTIVE SUMMARY}

Wastewater at Oak Ridge National Laboratory (ORNL) is collected, evaporated, and stored in the Melton Valley Storage Tanks (MVST) pending treatment for disposal. The waste separates into two phases: sludge and supernatant. Some of the supernatant from these tanks has been decanted, solidified into a grout, and stored for disposal as a solid low-level waste. The sludges in the tank bottoms have been accumulating for several years. Some of the sludges contain a high amount of gamma activity (e.g., ${ }^{137} \mathrm{Cs}$ concentration range of $0.013-11 \mathrm{MBq} / \mathrm{g}$ ) and contain enough transuranic (TRU) radioisotopes to be classified as TRU wastes. Some Resource Conservation and Recovery Act (RCRA) metal concentrations are high enough in the available total constituent analysis for the MVST sludge to be classified as RCRA hazardous; therefore, these sludges are presumed to be mixed TRU waste.

Grouting and vitrification are two stabilization/solidification alternatives for mixed wastes. Grouting has been used to stabilize/solidify hazardous and low-level radioactive waste for decades. Vitrification has been developed as a high-level radioactive alternative for decades and has been under development recently as a mixed waste alternative disposal technology.

An envelope, or operating window, for grout and glass formulations for a surrogate MVST sludge was identified and is documented in this report. Surrogate wet sludge loadings up to $55 \mathrm{wt} \%$ in grout met all performance criteria, resulting in volume increases of $40-50 \mathrm{vol} \%$ with little or no secondary waste generation. Higher loadings may result in free water, which violates the waste acceptance criteria of potential disposal facilities. Dewatering the sludge to $<52 \mathrm{wt} \%$ water allows higher waste loadings, with correspondingly lower volume increases, without sacrificing Toxicity Characteristic Leach Procedures (TCLP) performance or leach resistance. The grout strength declines as the sludge loading increases, but a strong monolithic solid is not usually a waste acceptance criterion. Grouts stabilized the RCRA metals, including mercury (potentially a problem species for the tank sludges), and passed the TCLP test.

The tank sludges can be stabilized in glass at a waste oxide loading of $40-50 \mathrm{wt} \%$, resulting in a . net volume decrease of $50-60 \mathrm{vol} \%$. This is a threefold decrease in the volume of the final waste form compared with grout, not counting the secondary-waste-generation volume from offgas treatment. The benefits of the lower glass volume compared with grout volume must be weighed against the generally higher capital and operating costs for vitrification, as well as the volume of secondary waste generated from both vitrification and grouting. RCRA metals incorporated into the glass matrix are stabilized and leach resistant, but mercury is volatilized and must be treated in the off-gas.

Confirmation of these results with actual hot sludge must be done prior to final acceptance of either technique. 



\title{
GROUT AND GLASS PERFORMANCE IN SUPPORT OF STABILIZATION /SOLIDIFICATION OF THE MVST TANK SLUDGES
}

\author{
R. D. Spence and T. M. Gilliam
}

\section{INTRODUCTION}

Wastewater at Oak Ridge National Laboratory (ORNL) is collected, evaporated, and stored in the Melton Valley Storage Tanks (MVST) pending treatment for disposal. The waste separates into two phases: sludge and supernatant. Some of the supernatant from these tanks has been decanted, solidified into a grout, and stored for disposal as a solid low-level waste. The sludges in the tank bottoms have been accumulating for several years. Some of the sludges contain a high amount of gamma activity (e.g., ${ }^{137} \mathrm{Cs}$ concentration range of $0.013-11 \mathrm{MBq} / \mathrm{g}$ ) and contain enough transuranic (TRU) radioisotopes to be classified as TRU wastes. Some Resource Conservation and Recovery Act (RCRA) metal concentrations are high enough in the available total constituent analysis for the MVST sludge to be classified as RCRA hazardous; therefore, these sludges are presumed to be mixed TRU waste.

Grouting and vitrification are two stabilization/solidification alternatives for mixed wastes. Grouting has been used to stabilize/solidify hazardous and low-level radioactive waste for decades. Vitrification has been developed as a high-level radioactive alternative for decades and has been under development recently as a mixed-waste alternative disposal technology.

\section{OBJECTIVE}

The objective of this project is to define an envelope, or operating window, for grout and glass formulations for MVST sludges. This objective is to be accomplished using surrogates of the MVST sludges and supernates.

\section{SURROGATES}

The composition of the MVST sludges and supernates was estimated using the available characterization data. ${ }^{1,2}$ This characterization data mainly reports the elemental concentrations, although the inorganic carbon (IC) was reported for the sludge and some anions were reported for the supernates. For purposes of developing MVST surrogates, the IC was assumed to be carbonate. The other anions measured in the supernates were estimated for the sludges by assuming the water contained in the sludge had the same concentration of the anions. The soluble salts in the sludges were assumed to be sodium salts with the potassium as nitrate. The undissolved solids were assumed to be mainly alkaline carbonates and hydroxides. This approach accounted for the anions that were reported in the data. The remainder of the measured 
elements were assumed to be oxides in an attempt to close the mass balance and determine whether a large unknown mass had not been characterized in the sludge.

\subsection{MVST SLUDGES}

Table 1 lists the calculated sludge compositions based on these assumptions in the attempt to close the mass balance. The row for unknown in Table 1 indicates that most of the mass was accounted for in the characterization data (with the assumptions discussed above). Only the sludges for tanks W-24 and W-25 had a significant unknown mass. Summarizing, the mass balance calculations accounted for $96,102,77,85,103,100,103$, and $100 \mathrm{wt} \%$ of the sludge mass in tanks W-21, W-23, W-24, W-25, W-26, W-27, W-28, and W-31, respectively. The weighted average composition listed in Table 1 was obtained by taking into account the estimated mass of sludge in each tank to obtain an overall sludge composition if all of the sludges were mixed. This weighted average composition was the basis for the proposed surrogate MVST sludge.

The last column under the RCRA metals in Table 1 lists the sludge concentration of the RCRA compound required to potentially generate a TCLP extract concentration equal to the Universal Treatment Standard (UTS) limit assuming total extraction during the TCLP test. In other words, if the sludge concentration is below the value listed in this last column for the RCRA metals, then it cannot fail the UTS criteria. From Table 1, the concentrations for the compounds of arsenic and barium do not exceed this critical value for any of the tank sludges; therefore, these two RCRA metals are not included in the surrogate. Also, from Table 1, the nickel compound concentration exceeded this critical value only for Tank W-23 and only by $10 \%$; plus, the weighted average did not exceed this critical value. Therefore, this RCRA metal is not included in the surrogate. In addition, thallium was not necessarily measured in the sludges; rather, the quantitation limit was high enough in most cases to prevent excluding thallium as a potential cause of failing the TCLP UTS limit, so thallium was included in the surrogate.

Table 2 lists the target composition for the surrogate MVST sludge. Table 2 lists $\mathrm{HgCl}_{2}$, rather than the $\mathrm{HgO}$ listed in Table 1 , because $\mathrm{HgCl}_{2}$ is much more soluble than $\mathrm{HgO}$ and would present much more of a challenge to stabilize, just in case the MVST sludges do fail the TCLP test for mercury. For similar reasons, Table 2 lists $\mathrm{Al}(\mathrm{OH})_{3}, \mathrm{Sr}\left(\mathrm{NO}_{3}\right)_{2}, \mathrm{Th}\left(\mathrm{NO}_{3}\right)_{4} \cdot 4 \mathrm{H}_{2} \mathrm{O}$, and $\mathrm{UO}_{2}\left(\mathrm{NO}_{3}\right)_{2} \cdot 6 \mathrm{H}_{2} \mathrm{O}$ rather than the $\mathrm{Al}_{2} \mathrm{O}_{3}, \mathrm{Sr}(\mathrm{OH})_{2}, \mathrm{ThO}_{2}$, and $\mathrm{UO}_{2}$ listed in Table 1, respectively.

\subsection{MVST SUPERNATES}

Table 3 lists the composition measured for the MVST supernates. The weighted average was obtained by using the quantity of supernate estimated for each tank. This weighted average forms the basis for the surrogate MVST supernate. The last column under the RCRA metals in Table 3 lists the UTS wastewater limits for these RCRA metals, unlike Table 1, which lists a value calculated from the nonwastewater UTS limits. The weighted average concentration did not 
exceed these limits for $\mathrm{Ag}$, As, $\mathrm{Ni}$, or Se; therefore, these RCRA metals were not included in the surrogate MVST supernate.

Table 4 lists the compounds and their target concentrations for the surrogate MVST supernate. Table 5 lists the elemental or ionic concentrations of the Table 4 solution. The concentrations listed in Table 5 can be compared directly with the weighted average concentrations listed in Table 3.

\section{GROUT}

\subsection{SELECTION OF THE DRY BLEND ADDITIVES FOR FURTHER EVALUATION}

The inorganic additives historically used for stabilization/solidification are portland cement, fly ash, lime, and clay but also included are blast furnace slag, cement kiln dust, high alumina cements, natural pozzolans, masonry cements, special cements, and cement admixtures. ${ }^{3,4}$ Conner cites the following reasons for the widespread use of these materials in treating wastes: ${ }^{3}$

- "Relatively low cost

- Good long-term stability, both physically and chemically

- Documented use on a variety of industrial wastes over a period of at least ten years

- Widespread availability of the chemical ingredients

- Nontoxicity of the chemical ingredients

- Ease of use in processing (processing normally operated at ambient temperature and pressure and without unique or very special equipment)

- Wide range of volume increase

- Inertness to ultraviolet radiation

- High resistance to biodegradation

- Low water solubility

- Relatively low water permeability

- Good mechanical and structural characteristics"

The International Atomic Energy Agency lists the following advantages and disadvantages of cement for the solidification of radioactive wastes: ${ }^{4}$

\section{“Advantages}

- Material and technology well known;

- Compatible with many types of waste;

- Most aqueous wastes chemically bound to matrix;

- Low cost of cement;

- Good self-shielding;

- No vapour problems;

- Long shelf life of cement powder; 
- Good impact and compressive strengths;

- Low leachability for some radionuclides;

- No free water if properly formulated;

- Rapid, controllable setting, without settling or segregation during curing.

\section{Disadvantages}

- Some wastes affect setting or otherwise produce poor waste forms.

- $\mathrm{pH}$ adjustment of waste may be necessary.

- Swelling and cracking occur with some products when they are exposed to water.

- Volume increase and high density may develop.

- Excessive heat may develop during setting with certain combinations of cement and waste.

- Dust problems may occur with some systems.

- Equipment for powder feeding is difficult to maintain.

- Potential maintenance problems may result from premature cement setting, especially in the case of in-line mixers."

Portland cement, fly ash, Indian Red Pottery Clay (IRPC), ground granulated blast furnace slag, and water sorptive agents were selected for use in this study. A brief history and reason for selection are presented in the following subsections for each material.

\subsubsection{Portland Cement}

Portland cement, its composition, and its chemistry are discussed in great detail in several references and will not be discussed in detail in this report. ${ }^{3-9}$ The main points of interest for cement stabilization/solidification are the (1) normal high $\mathrm{pH}$ of cement matrices, (2) production of calcium hydroxide in normal cement hydration, and (3) strong binding matrix resistant to advective water flow and leaching interacting with and encapsulating the waste. Wastes are generally physically encapsulated heterogeneously in the calcium-silicate-hydrate (CSH) matrix, with the level of dispersion and homogeneity generally dependent on the energy and effort put into physically mixing waste and cement. Despite the inherent composite nature of cement waste forms, the wastes strongly interact with the cement, stabilizing contaminants as desired and sometimes interfering with cement hydration, which is not desired. Although there is evidence that some contaminants are incorporated into the CSH matrix, the main stabilizing mechanism of cement waste forms is the high $\mathrm{pH}$ matrix, similar to the lime precipitation of metals in wastewater treatment.

This high $\mathrm{pH}$ precipitation captures most of the RCRA metals and radionuclides. For example, the low solubility at high $\mathrm{pH}$ of $\mathrm{Cu}, \mathrm{Ni}, \mathrm{Fe}, \mathrm{Cd}, \mathrm{Zn}, \mathrm{Ag}$, and $\mathrm{Pb}$ is illustrated in the published solubility curves with $\mathrm{pH}^{3,10}$ In general, these solubility curves pass through a minimum as the $\mathrm{pH}$ increases, meaning these metals actually start becoming more soluble as the $\mathrm{pH}$ passes a certain point, with the generation of complex hydroxide ions. The minimum solubility for these metals occurs in a pH range of about 9 to slightly more than 11 . The normal production of 
calcium hydroxide during cement hydration and the presence of alkalis in the cement can produce a pore solution $\mathrm{pH}$ in the range of $12-13$, which is well above the minimum solubility for most of these metals. ${ }^{3}$ This combination (high matrix $\mathrm{pH}$ and increasing metal solubility at this $\mathrm{pH}$ level) can actually increase the leachability of some wastes after treatment. This is one reason neat cement pastes are a poor choice for stabilizing wastes and why cement-fly ash combinations are almost always used. Fly ash consumes the calcium hydroxide produced during cement hydration, (1) moderating the matrix $\mathrm{pH}$ and (2) eliminating the large soluble portlandite crystals (these crystals dissolve upon immersion, leaving large accessible pores in the matrix, increasing porosity and leachability) found in neat cement pastes. Cementitious waste forms (typically cement-fly ash) reportedly have a $\mathrm{pH}$ of about 11 , which is much better suited for minimizing metal solubility. ${ }^{3}$ The solubility behavior of the RCRA metals in cement waste forms mimics these solubility curves to a certain degree, but differ enough to illustrate that "... f factors other than hydroxide precipitation are in operation ...." 3,11

Cements are produced and sold in many forms, any of which may be suitable for stabilizing wastes. Portland cements are the most commonly available cements, typically locally available and cheap. The ASTM standards specify five standard portland cements with optional properties available within each type: ${ }^{3,12}$

\section{ASTM-Type portland cement \\ I}

II

III

IV

\author{
Description \\ General-purpose portland cement and \\ usually the least expensive \\ Moderate sulfate resistance and \\ moderate heat of hydration, Type II fly ash is \\ typical substitute when job size can't justify Type \\ IV production
}

High early strength and cold weather use

Low heat of hydration, used in massive structures (e.g., dams) where temperature rise can approach adiabatic, generally not available, mass produced for specific jobs

V

\section{Sulfate resistant}

ASTM Type I portland cement is most commonly used for waste stabilization because of its wider availability and lower cost and can work in most cases with proper tailoring. The way the ASTM specifications are written, ASTM Type II portland cement can be considered a subset of ASTM Type I portland cement, and quite often cement is marketed as Type I-II portland cement. If Type II portland cement is locally available, it may be better to specify Type II because of its 
better sulfate resistance and lower heat of hydration (many wastes contain sulfate and the heat of hydration can be a concern for some waste form applications). In addition, specifying the options of low alkali (LA) and low alumina (if available) may be desirable to make the final waste form more resistant to later destructive expansion from minerals, such as alkali silicates, ettringite, or calcium chloroaluminate.

In summary, the best a priori cement selection may be ASTM Type II portland cement-LA-low alumina-moderate heat of hydration. However, any of the cement types may be satisfactory for a given application and such selections should be made on a case-by-case basis, depending on waste composition, cement availability, technical performance, and costs. In the present study, the main function of the cement selected was to ensure activation of the ground granulated blast furnace slag; hence, it was not necessary to specify the cement listed above since it would not provide the basic waste form matrix. Type I, Type II, or Type I-II would be equally appropriate for this task, although Type II or I-II would still be preferred, if readily available, because of better sulfate resistance.

\subsubsection{Fly Ash}

Fly ash is an active pozzolan source that reacts with the caustic alkalis and alkalines, consuming hydroxide and producing alkali silicates and more CSH. Fly ash is only one of several possible pozzolans that can be used with cement or lime to produce cementitious waste forms. Other pozzolan candidates include volcanic glasses, volcanic tuffs, calcined clays and shales, diatomites, rice husk ash, volatilized silica (silica fume), blast furnace slag, and other slags. ${ }^{4}$ The key to the reactivity of the fly ash (and many of the other pozzolans) is its glassy structure. Only the amorphous glassy form provides a soluble silica source for reacting with the lime (and other caustics). The crystalline forms, like mullite, are too insoluble, stable, and inert. Fly ash was used in construction concrete decades prior to its use in waste disposal. ${ }^{3,4,13-17}$

Using fly ash in concrete has many advantages in certain usages, the most important being cost, as it replaces $25-35 \mathrm{wt} \%$ of the portland cement normally used. ${ }^{3}$ Incorporating fly ash into cement lowers the heat of hydration, reducing curing temperature, an advantage in producing massive monoliths. ${ }^{4,15-17}$ Fly ash acts as both a pozzolan and a bulking agent, helping prevent settling in relatively low solids wastes and saving costs by substituting for cement. ${ }^{3}$ However, such bulking does result in larger volume and weight increases than for portland cement alone, "... usually only justified where low handling, transportation, and disposal costs are encountered." However, the relatively higher volume from fly ash is acceptable in its use as a pozzolan. Hydrating cement produces lime as a by-product that forms large soluble crystals in the cured neat cement paste matrix. These crystals dissolve upon immersion, leading to increased accessible porosity and leachability. Pozzolans react with this lime to produce more $\mathrm{CSH}$ to fill the available porosity, decreasing accessible porosity and leachability. In other words, fly ash "... helps to bind additional water, decrease the pore $\mathrm{pH}$, and act as an adsorbent for metal ions." 
Since strontium chemically behaves similarly to calcium, cement-pozzolans will also tend to tie up ${ }^{90} \mathrm{Sr}$ better than cement alone. Cement-fly ash has traditionally been the stabilizer of choice for ${ }^{90} \mathrm{Sr}$, although cement alone does stabilize ${ }^{90} \mathrm{Sr}$ quite well. ${ }^{13,18-21}$

The ASTM standards specify two fly ashes and one natural or calcined pozzolan for use in portland cement concrete: ${ }^{3,22}$

\begin{tabular}{cl}
$\frac{\text { ASTM Mineral }}{\text { Admixture Class }}$ & \multicolumn{1}{c}{$\begin{array}{c}\text { Description } \\
\mathrm{N}\end{array}$} \\
$\mathrm{F}$ & $\begin{array}{l}\text { Raw or calcined natural pozzolans } \\
\text { Fly ash normally produced from } \\
\text { anthracite or bituminous coal, has } \\
\text { pozzolanic properties }\end{array}$ \\
$\mathrm{C}$ & $\begin{array}{l}\text { Fly ash normally produced from lignite } \\
\text { or subbituminous coal, has pozzolanic } \\
\text { and cementitious properties, may contain } \\
\text { lime contents }>10 \%\end{array}$
\end{tabular}

In general, a commercial industry has evolved to supply fly ash cheaply and with adequate QAVQC to routinely meet ASTM standards, making a valuable by-product out of the large amounts of waste produced daily in the coal-fired power plants across the country. Although both can be and have been used, ASTM Class F fly ash is generally preferred for waste treatment, because of the possibility of "flash set" in the equipment with ASTM Class C fly ash. This difference in reactivity is indirectly related to the higher minimum specified content of silica, alumina, and iron oxide for Class F ( $270 \mathrm{wt} \%)$ compared with Class C ( $250 \mathrm{wt} \%)$. Although the lime content is not specified in the standard, a large fraction of the remaining composition is "free lime," which can lead to hydraulic cementitious reactions within the fly ash. Typically, the low lime content of Class F fly ash is quickly consumed, leaving the bulk of the fly ash relatively inert until caustically activated (e.g., by mixing with cement and the subsequent production of lime from hydration). The lime content of Class $\mathrm{C}$ fly ash can be as high as $30 \mathrm{wt}$ $\%$ or higher, a highly reactive mix that can set into a cementitious product in a matter of minutes upon mixing with water (flash set). Since the lime content is not specified by the standard, the fly ash lime content varies from source to source and can vary from batch to batch. For these reasons, ASTM Class F fly ash was selected for this study.

\subsubsection{Indian Red Pottery Clay}

Over the years, illite (IRPC), $(\mathrm{OH})_{4} \mathrm{~K}_{x}\left(\mathrm{Al}_{4} \mathrm{Fe}_{4} \mathrm{Mg}_{4} \mathrm{Mg}_{6}\right)\left(\mathrm{Si}_{8-x} \mathrm{Al}\right) \mathrm{O}_{20}$, has become a proven standard additive in grout formulation development at ORNL for making cementitious waste forms more resistant to the leaching of ${ }^{137} \mathrm{Cs} .{ }^{19,20,23-25}$ Illite has been known as an effective selective sorbent for ${ }^{137} \mathrm{Cs}$ for decades. ${ }^{26-28}$ The gap between illite layers is apparently ideal to allow cesium ions to diffuse between the clay layers and essentially irreversibly trap these ions. Although there are other illitic sources (e.g., conasauga shale), IRPC is the most readily available commercial 
source. The standard recipe evolved into $8 \mathrm{wt} \%$ of IRPC in the dry blend of cementitious materials used to stabilize/solidify the waste liquids, solids, or sludges. The $8 \mathrm{wt} \%$ in the dry blend was far in excess of the stoichiometric amount needed to load the typical ${ }^{137} \mathrm{Cs}$ contamination found in the wastes into the clay, because even a waste with high gamma activity from ${ }^{137} \mathrm{Cs}$ has a rather low concentration of ${ }^{137} \mathrm{Cs}$ on a molar basis. The main reason for $8 \mathrm{wt} \%$ IRPC in the dry blend was to distribute enough IRPC throughout the waste form so that all of the ${ }^{137} \mathrm{Cs}$ had access to the IRPC and mass transport distances were minimized. This strategy has served well for many years, as indicated by the high ANSI/ANS-16.1 leachability indexes reported for ${ }^{137} \mathrm{Cs}$ over the years for grouts containing IRPC.

\subsubsection{Ground Granulated Blast Furnace Slag}

Blast furnace slag is a normal by-product of the iron and steel industry. In general, the slag is cooled in two ways (1) air cooling and (2) water quenching (granulation). Air cooling produces an inert crystalline slag useful only as an inert fill material but useless as a cement substitute. The essential components of slag are the same oxides as are present in portland cement but "... for use as a cement, rapid cooling is necessary to quench the material to form a reactive glass and to prevent the crystallization of unreacted chemical compounds." Granulated slag hydrates slowly on contact with water but is activated by caustics (e.g., calcium hydroxide or sodium hydroxide), calcium sulfate, sodium carbonate, and sodium sulfate. ${ }^{4}$ The granulated slag is finely ground and marketed as a substitute for cement. The ground granulated blast furnace slags (slags) ". . . have physical properties similar to those of ordinary portland cements. The distribution of particle size and the surface area of blast-furnace slags depend on the method of manufacture, but in general their fineness is similar to that of portland cements." ${ }^{.4,29}$

Slags have been substituted for cement for decades. ${ }^{30}$ Slags hydrate slowly to form CSH, the same product formed by cements, but slag alters the morphology and properties of the final product, sometimes in subtle ways, but beneficially in general: ${ }^{4,30-37}$

- early strength development is slower,

- heats of hydration are lower,

- sulfate resistance is improved,

- lower permeability despite increased total porosity,

- improved frost resistance,

- lower ionic diffusion rates,

- increased salt stability,

- reduced setting rate,

- extended working time,

- pore water contains sulfur species in addition to hydroxide anions,

- high $\mathrm{pH}$ and low oxygen potential,

- reduced solubility of most contaminants,

- reduced rate of corrosion of steel containers, and 
- other physical and mechanical properties similar to portland cements (e.g., density and compressive strength).

A slag:cement combination of 75:25 virtually eliminates calcium hydroxide as a hydration product; that is, the presence of excess slag prevents buildup of this cement hydration product. ${ }^{4}$ This implies that the proper proportion of slag-cement can replace cement-fly ash to stabilize ${ }^{90} \mathrm{Sr}$. In addition, a combination of 85:15 or higher slag produces a strong reducing environment within the matrix, suitable for reducing pertechnetates or chromates. ${ }^{38,39}$ Thus, slags have been used in grouts developed for radioactive and mixed wastes for a long time. ${ }^{38-48}$

The ASTM standards specifys three strength grades of ground granulated blast furnace slag for use in concrete and mortars based on the slag activity index: ${ }^{49}$

$\underline{\text { ASTM Slag Grade }}$ 80 100 120

\begin{tabular}{|c|c|}
\hline \multicolumn{2}{|c|}{$\begin{array}{l}\text { Minimum Average Slag } \\
\text { Activity Index, \% }\end{array}$} \\
\hline 7 days & 28 days \\
\hline & 75 \\
\hline 75 & 95 \\
\hline 95 & 115 \\
\hline
\end{tabular}

These slag grades are important for construction purposes but not necessarily for waste treatment, where strength requirements are usually minimal. The chemical properties of commercially available slag, not their strength, are important to waste treatment and are generally not specified in the ASTM standard. Perhaps the most important property regarding waste treatment measured in the standard is the air permeability or Blaine fineness, although no limits are specified..$^{50}$ Finer slag usually means a lower permeability, not only in the dry slag but also in the resulting cementitious matrix. A lower permeability implies "... improved resistance to frost, lower diffusion rates of ions through the hardened cement and improved stability in the presence of salts, such as chloride and sulphate."4,36 Typically, portland cement has a Blaine fineness of $3000-4000 \mathrm{~cm}^{2} / \mathrm{g}$ and slag, a fitness of $4000-5000 \mathrm{~cm}^{2} / \mathrm{g}$, but slag $>5000 \mathrm{~cm}^{2} / \mathrm{g}$, or even $>6000 \mathrm{~cm}^{2} / \mathrm{g}$, can sometimes be acquired. In general, the finer, the better, although it is unlikely that special requests for finer grinding is worth the additional costs. Any commercially available slag suitable as a cement substitute generally improves the matrix properties and imparts the desired properties to the final waste form. In summary, ground granulated blast furnace slag with a Blaine fineness of $>4000 \mathrm{~cm}^{2} / \mathrm{g}$ was selected for this study.

\subsubsection{Water Sorptive Agents}

When a grout is poured and allowed to remain static, the binding and pozzolanic agents (cement, fly ash, slag) tend to settle, leaving a drainable liquid on the grout surface (phase separation, bleed water, freestanding liquid, or free water). ${ }^{51-53}$ Traditionally, two methods have been used to control this free water generation: (1) increasing the solids-to-liquid mix ratio (or inversely decreasing the liquid, or water-to-solids ratio, W/S) and (2) adding gel clays. Gel clays disperse 
in water and form a thick, stable colloidal gel when mixing stops. This prevents suspended particles, such as fly ash, cement, or slag, from settling while minimizing the dry blend added for treatment and the subsequent volume increase. The gel clays from oil field drilling fluids (muds) were adapted for this purpose in waste treatment grouts.

Water sorptive clays have been used in geotechnical applications, such as construction (slurry walls and clay caps) and drilling (drilling muds and cement mixes), for decades to resist solids segregation (suspension aid), prevent bleed water, and act as an engineered hydraulic barrier to water penetration (into a construction zone, waste disposal site, etc.). The most commonly used clay for these purposes is bentonite, sodium montmorillonite, “... a colloidal clay mined in Wyoming and South Dakota. It imparts viscosity and thixotropic properties to fresh water by swelling to about 10 times its original volume. Bentonite (or gel) was one of the earliest additives in oilwell cements to decrease slurry weight and to increase slurry volume." ${ }^{.54,55}$ The individual clay particles of bentonite are plate-shaped. The particle faces are positively charged, while the edges are negatively charged. When mixed with water, the platelets separate and disperse throughout the fluid. When mixing ceases, the clay particles form a multilayered colloidal gel structure due to the attraction of opposite charges. However, the electrostatic double-layer forces are lessened with increasing ionic strength. ${ }^{53,56}$ Consequently, high-salt solutions (notably chloride, sulfate, and phosphate salts, as well as acids and bases) collapse these gels, lessening their dispersive effectiveness and releasing the large volume of water collected around the clay particles (i.e., free water can form if salt solutions are grouted). ${ }^{53,57}$

This susceptibility compromised the use of bentonite in off-shore oil drilling in salty waters. For this reason, attapulgite was adapted as the gel clay used in such salty applications, because attapulgite clay particles carry no charge and are not affected by high salt content..$^{53}$ The individual attapulgite particles resemble needles, rather than platelets. When mixed with water, these needles are dispersed throughout the fluid and become aligned along shear planes. When mixing ceases, a gel structure is formed by the random entanglement of these particles, referred to as a "brush-heap effect." Attapulgite is commercially available only from northern Florida and southern Georgia. ${ }^{53}$ Thus, attapulgite has been adopted as the gel clay of choice for salty wastes. Note that although several forms of attapulgite have been tested for DOE salty wastes, only attapulgite 150 (Attagel 150) proved effective. ${ }^{53,58}$

The American Petroleum Institute (API) issued specifications for both bentonite and attapulgite..$^{59,60}$

In general, the hazardous waste industry adopted a different strategy for the treatment of low solids wastes (i.e., waste waters and watery sludges), although clays were not eschewed. Practically any water sorptive agent was considered a candidate, but sodium silicate may have been the most popular, resulting in numerous patents. ${ }^{3}$ Sodium silicate forms a hydrogel, a threedimensional polymeric structure incorporating up to $90 \%$ water; that is, a little sodium silicate can accommodate a lot of water. Adding sodium silicate to the grout can be quite effective at controlling free water generation and generally results in a grout with a smooth surface sheen 
appearance, as opposed to the usual rough wet paste appearance. Sodium silicate does thicken immediately upon mixing with cement. For this reason, it may be added as the last step in mixing to prevent any mixing problems. Hydrogels are subject to frost or dessication damage, not unexpectedly with such a large water content, so care should be exercised about using hydrogels if the waste form will be stored aboveground (or the above the frost line) and/or exposed to freezing or drying conditions.

Another cheap, water sorptive bulking agent is perlite. "Perlite is a volcanic material that is mined, crushed, screened, and expanded by heat to form cellular product of extremely low bulk weight." 54 Water is absorbed by capillary action within the large volume of pore structure within this light, porous product.

In summary, the water sorptive agents selected for testing were bentonite, attapulgite, and perlite.

\subsection{SELECTING GROUT COMPOSITION FOR EVALUATION}

The initial basis for a dry blend were the cement-fly ash dry blends historically developed for treatment of radioactive wastes:

Type I portland cement

Class $\mathrm{F}$ fly ash

Attapulgite 150 drilling clay

IRPC

\begin{tabular}{|c|}
\hline \\
\hline \\
\hline \\
\hline drofracture ${ }^{23} \quad$ Hanford $^{72}$ \\
\hline
\end{tabular}

42

34

16

8
38

39

15

8

Typically, a mix ratio of 0.84 and $0.72 \mathrm{~kg}$ dry blend/L waste ( 7 and $6 \mathrm{lb}$ dry blend/gal waste) was tested for these two applications. ${ }^{23,52}$ Assuming a waste specific gravity of about $1.2(10 \mathrm{lb} / \mathrm{gal})$, these mix ratios give waste loadings of about $60 \mathrm{wt} \%$. Thus, strong monoliths can be expected at waste loadings up to $60 \mathrm{wt} \%$, although some problems with bleed water may be experienced, depending on the water content of the waste and the steps taken to control bleed water. Note that approximately equal proportions of cement-fly ash were used with $8 \mathrm{wt} \%$ IRPC. These two grouts were developed for low solids wastes, and the need for a large fraction of water sorptive agent in the dry blend was uncertain a priori for the present tank sludge application (the goal was to develop a grout for the sludge interstitial water content as it rests in the tanks, ignoring retrieval or pretreatment requirements). Hence, the water sorptive content was varied, dropping to zero, but increased as needed, depending on the agent and performance. In addition, slag replaced cement as the binder of choice. Cement was included to activate the slag, but a slag:cement combination of about 90:10 was maintained to enhance the reducing capability of the matrix. In general, IRPC was fixed in the dry blend at $8 \mathrm{wt} \%$ for ${ }^{137} \mathrm{Cs}$ stabilization. The fly ash was kept as a proven pozzolan for ${ }^{90} \mathrm{Sr}$ stabilization. (The main mobile radionuclides of interest in these tank sludges are ${ }^{137} \mathrm{Cs}$ and ${ }^{90} \mathrm{Sr}$.) The fly ash content was allowed to float to compensate for the varying content of water sorptive agent. 
Summarizing, the dry blend guidelines used to initiate experimental work were as follows:

Strong monoliths are expected with waste loadings up to $60 \mathrm{wt} \%$ or higher. In general, strength decreases with waste loading or clay content.

\subsection{EXPERIMENTAL}

\subsubsection{Surrogate Preparation}

The surrogate MVST wet sludge was prepared from reagent-grade chemicals according to the composition listed in Table 2 . The chemicals were allowed to hydrolyze by mixing with the recipe water at least overnight. One-liter batches of the surrogate MVST supernate were prepared from reagent-grade chemicals according to the composition listed in Table 4 and used extra water as needed in the grout mixing.

\subsubsection{Blending}

The dry blends mixed with the surrogate wet sludge to make grouts consisted of blends of two or more of the following dry powders: (1) ground granulated blast furnace slag (slag) with a Blaine fineness of $6220 \mathrm{~cm}^{2} / \mathrm{g}$ from the Koch Minerals Co., (2) Type I-II portland cement (cement) from the Dixie Cement Co., (3) Class F fly ash (fly ash) from the American Fly Ash Co., (4) Grade H200 perlite from the Harborlite Corp. (perlite), (5) IRPC from the American Art Clay Co., (6) Attapulgite 150 ground clay (attapulgite) from the Engelhardt Corp., and (7) bentonite clay (bentonite) from the Benton Clay Co. The dry blends were blended for $2 \mathrm{~h}$ in an 8-qt twin-shell blender (or V-blender) from the Patterson-Kelley Co.

\subsubsection{Mixing}

The grouts were mixed in a Model N-50 Hobart mixer using a wire whip. The surrogate wet sludge was added to the Hobart bowl first, then the dry blend was added to the sludge while mixing on low speed (30-60 s). The grout was then mixed on low speed for 2 min and medium speed for $2 \mathrm{~min}$, cast into containers or molds for performance testing, and cured. The procedure for spiking with radionuclides for making leach samples consisted of adding the spike to the wet sludge in the Hobart bowl, mixing on low speed for $20 \mathrm{~m}$, then adding the dry blend using the above procedure. 


\subsubsection{Curing}

The freshly made grout was stored in a humidity cabinet and cured in a humid environment at $30 \pm 1^{\circ} \mathrm{C}$. The samples were cured only $7 \mathrm{~d}$ for the scope testing, but the sensitivity samples were cured for the standard 28 days.

\subsubsection{Performance Testing}

The performance testing for the scope testing consisted of measuring the density, the penetration resistance, free water (or bleed water), and TCLP performance after only $7 \mathrm{~d}$. The sensitivity testing consisted of measuring the density, 28-d unconfined compressive strength, 28-d free water, 28-d TCLP performance, and the 28-d leachability index of ${ }^{85} \mathrm{Sr}$ and ${ }^{137} \mathrm{Cs}$.

The free water was measured by casting $250 \mathrm{~mL}$ of grout into a graduated cylinder and measuring the volume of free water standing over the solid grout. This property is reported as volume percent, calculated by dividing the observed free water volume, as measured in milliliters, by $250 \mathrm{~mL}$ and multiplying by 100 .

The density of the freshly mixed grout was obtained by measuring the net mass in grams of the $250 \mathrm{~mL}$ of grout in the free water test and dividing by $250 \mathrm{~mL}$ to obtain the density in units of $\mathrm{g} / \mathrm{mL}$. The density of the surrogate grouts was also obtained using the graduated cylinders.

For penetration resistance, the force $\left(\mathrm{lb}_{\mathrm{f}}\right)$ to push a flat rod with a cross-sectional area of $1 / 40 \mathrm{in}^{2}$, a preset distance into the curing grout was measured. This force was divided by the crosssectional area and reported as penetration resistance (psi). The gauge on the penetrometer read a maximum force of $200 \mathrm{lb}_{\mathrm{f}}$, limiting measurements on penetration resistance to $8000 \mathrm{psi}$.

For the unconfined compressive strength, nominal 2-in. cubes of grout were cast and cured. After curing $28 \mathrm{~d}$, the cube dimensions were measured and the force $\left(\mathrm{lb}_{\mathrm{f}}\right)$ required to crush the cube measured on a Tinius-Olsen Machine. Dividing the crushing force by the cube crosssectional area gave the unconfined compressive strength (psi).

A modified TCLP test was performed for this study. The modified procedure extracts a $10-\mathrm{g}$ sample with $200 \mathrm{~mL}$ of extractant, rather than the standard $200-\mathrm{g}$ extraction with $2 \mathrm{~L}$ of extractant. The TCLP test uses one of two extractants: (1) an acetic acid solution with sodium hydroxide added (TCLP Extraction Fluid No. 1, $\mathrm{pH}$ of about 4.9) or (2) the straight acetic acid solution (TCLP Extraction Fluid No. 2, pH of about 2.9). (The procedure dictates which extractant to use based on the buffering capability of the sample when mixed with a hydrochloric acid solution.) After extracting $18 \mathrm{~h}$, the undissolved solids are filtered from the extract and the extract is digested using a microwave digester. The concentrations of the inorganic RCRA metals in the extract, were then measured using a Thermo Jarrel Ash ICAP 61E Trace Analyzer (ICP). Although selenium and arsenic analyses by ICP are not usually accepted, EPA accepts the 
higher sensitivity of the 61E. Some mercury analysis was also performed on the 61E, but mercury analysis by ICP is still not accepted by EPA, including the 61E.

For the leachability index, a semidynamic leach test was performed using a modification of the ANSV/ANS-16.1 test. (In a semidynamic test, the samples remain quiescent in the leachate for a set time interval and are then moved to a fresh leachate at zero concentration for the next time interval.) The grout samples were leached in deionized water. The concentration of the radionulides were measured by gamma spectroscopy using a germanium detector with an efficiency of $10 \%$ and a background of 30 counts per $1000 \mathrm{~s}$, or 0.03 counts per second (cps). After a 30-s rinse, the leachates were changed at cumulative times of $1,2,3,4$, and $7 \mathrm{~d}$. The effective diffusion coefficient was estimated from the cumulative fraction leached with time, assuming diffusion-controlled leaching. The leachability index is the negative of the logarithm of the effective diffusion coefficient.

\subsection{RESULTS AND DISCUSSION}

The experimental work consisted of two phases: scope testing and sensitivity testing. The scope testing explored the waste form behavior for a limited set of performance tests over a range of compositions to establish an envelope of waste form compositions meeting the performance criteria ( $<0.5 \mathrm{vol} \%$ free water, passes TCLP, and hardens into a monolithic solid waste form). After establishing this envelope, an acceptable formulation was selected for testing the sensitivity of the formulation to variations in the formulation and surrogate composition.

\subsubsection{Scoping Tests}

Table 6 lists the compositions of the grouts tested during the scoping tests. Table 7 lists the densities measured for these grouts and the ratios of the grout volume to wet sludge volume calculated from these grout densities, the wet sludge loadings, and the surrogate MVST sludge density $(1.40 \mathrm{~g} / \mathrm{mL})$. Figure1 illustrates the dependence of these grout densities on the W/S of these grouts. Figure 2 illustrates the dependence of the ratio of grout volume to wet sludge volume on the wet sludge loading in the grout. Table 8 lists the free waters and penetration resistances measured for these grouts. Table 9 lists the TCLP extract concentrations measured for the surrogate sludge, and Table 10 lists the TCLP extract concentrations measured for the scoping test grouts.

The first 12 grouts established the performance of two dry blends using no water sorptive agents: (1) $83,0,9$, and $8 \mathrm{wt} \%$ and (2) $41,46,5$, and $8 \mathrm{wt} \%$ of slag, fly ash, cement, and IRPC, respectively. The first two grouts established the water demand nature of the surrogate sludge and blends. First, the dry blends were added to the wet sludge until the resulting grouts were too dry (wet sludge loadings of 37 and $33 \mathrm{wt} \%$ and W/S of 0.24 and 0.21 for blends 1 and 2, respectively). Next, surrogate MVST supernate was added until the grouts were judged to be processable wet plastic masses (the final grout compositions listed in Table 6 for grouts 1 and 2). Prior work with wastewater treatment sludges had obtained satisfactory performance with wet 


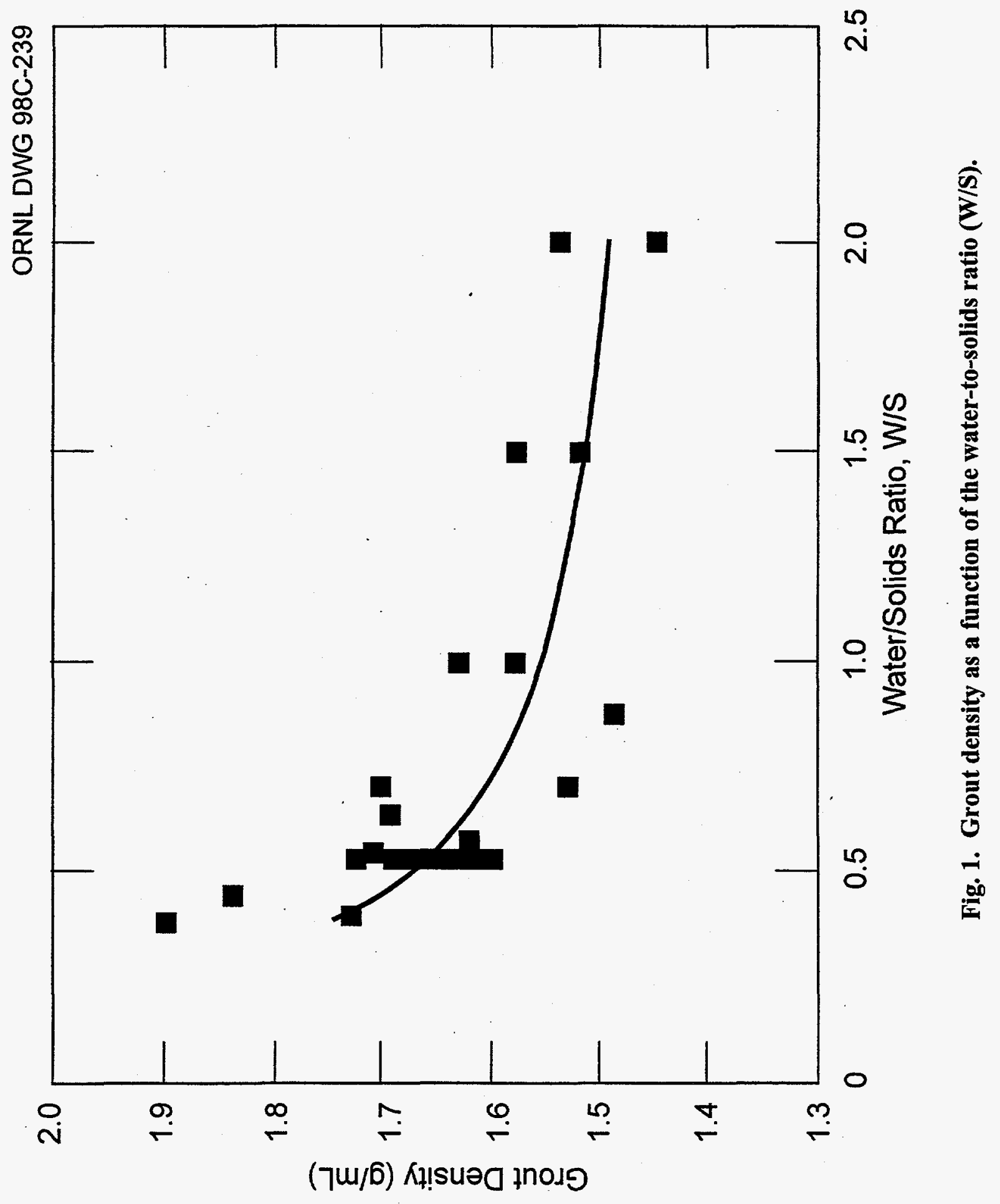




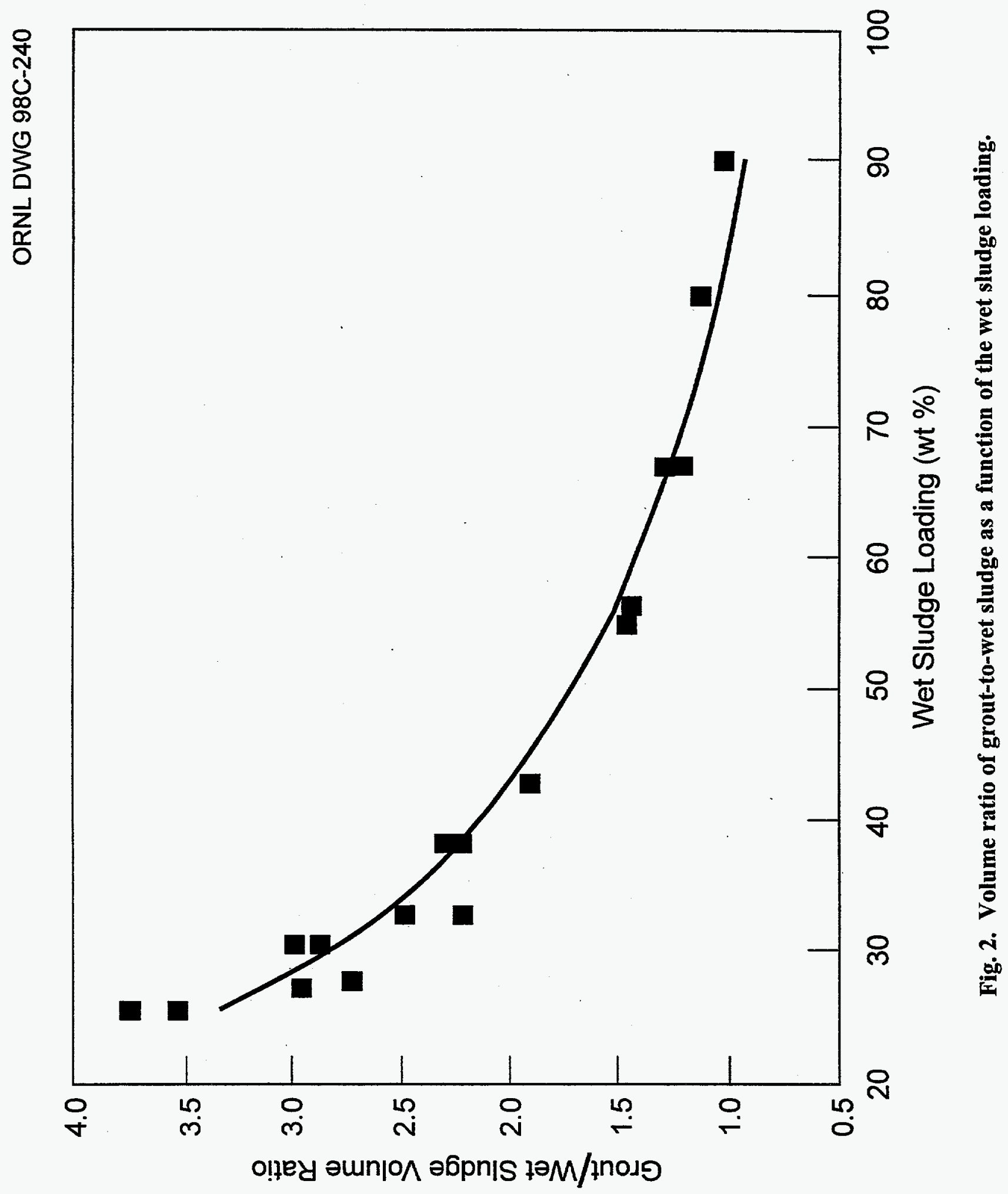


sludge loadings of $67 \mathrm{wt} \%$, so these two dry blends were tested at this loading, as well as testing the free water performance over a range of W/S, using the surrogate supernate to adjust the W/S. Figure 3 illustrates the free water obtained for these 12 grouts as a function of the W/S.

These results established that the W/S needs to be about 0.4 or more for the grout to be processable, but that free water can be a problem above W/S of 0.4 . (The surrogate sludge consisted of two phases with a free water content of $15.6 \mathrm{vol} \%$, so its free water performance may not be representative of the MVST sludges resting on the tank bottoms. The W/S of the surrogate sludge was 1.08 , and to achieve a W/S of 0.4 , enough dry blend must be added to make a grout with $55 \mathrm{wt} \%$ wet sludge loading.) Having no free water is a regulatory and waste acceptance criteria, and a major driver for establishing the grout composition and an acceptable operating envelope. Consequently, the next 20 grouts were devoted to testing water sorptive agents in an attempt to control the bleed water and allow higher wet sludge loadings (in lieu of dewatering). These grouts were made with a constant amount of dry blend (wet sludge loading of $67 \mathrm{wt} \%$ and W/S of 0.53 ) and varying amounts of different water sorptive agents in the dry blend, concentrating on dry blends with large amounts of fly ash (the traditional additive used to stabilize ${ }^{90} \mathrm{Sr}$ ). Figure 4 illustrates the free water performance of these grouts as a function of the amount of water sorptive agent in the dry blend. The water sorptive agents tested were perlite, attapulgite, and bentonite. Perlite at $20 \mathrm{wt} \%$ in the dry blend proved to result in the lowest free water after $7 \mathrm{~d}$ for these water sorptive agents. This dry blend still resulted in significant free water at $7 \mathrm{~d}$, so increasing the cement in this dry blend was tested to further reduce the free water (the dry blends contained $4 \mathrm{wt} \%$ cement to this point). As illustrated in Fig. 4, the minimum free water was obtained with $20 \mathrm{wt} \%$ cement and $20 \mathrm{wt} \%$ perlite in the dry blend. This dry blend $(33,20,19,20$, and $8 \mathrm{wt} \%$ of slag, cement, fly ash, perlite, and IRPC, respectively) was selected as the standard for further testing.

The last seven grouts in the scoping tests used this dry blend at wet sludge loadings ranging from 27 to $90 \mathrm{wt} \%$. Figures 5 and 6 illustrate the 7-d free water and 7-d penetration resistance, respectively, with wet sludge loading for these grouts. As Fig. 5 illustrates, some free water occurs as the wet sludge loading exceeds $55 \mathrm{wt} \%$; therefore, the grout loading for this sludge is limited to $55 \mathrm{wt} \%$ because of the free water criteria, unless the wet sludge is dewatered. As Fig. 6 illustrates, all of the grouts hardened, except at a wet sludge loading of $90 \mathrm{wt} \%$. The 7-d penetration resistance did decline significantly above wet sludge loadings of $60 \mathrm{wt} \%$. (Note that measurement of penetration resistance was limited to 8000 psi, and the first four points plotted in Fig. 6 exceeded this value but were plotted at this limit.)

From Table 9, the surrogate MVST sludge would have been characteristically hazardous only for mercury by the RCRA characteristic limits and, similarly, would have passed the TCLP (Land Disposal Restrictions (LDR) criteria, except for mercury. However, the surrogate sludge did not meet the more stringent Universal Treatment Standard (UTS) criteria for Cd, Cr, $\mathrm{Hg}$, or Tl. In general, the scoping test grouts not only stabilized the mercury to meet TCLP LDR criteria but also passed the more stringent UTS criteria, except for selenium. Although the surrogate sludge did not fail for selenium, the TCLP extract concentrations of selenium for several of the scoping 


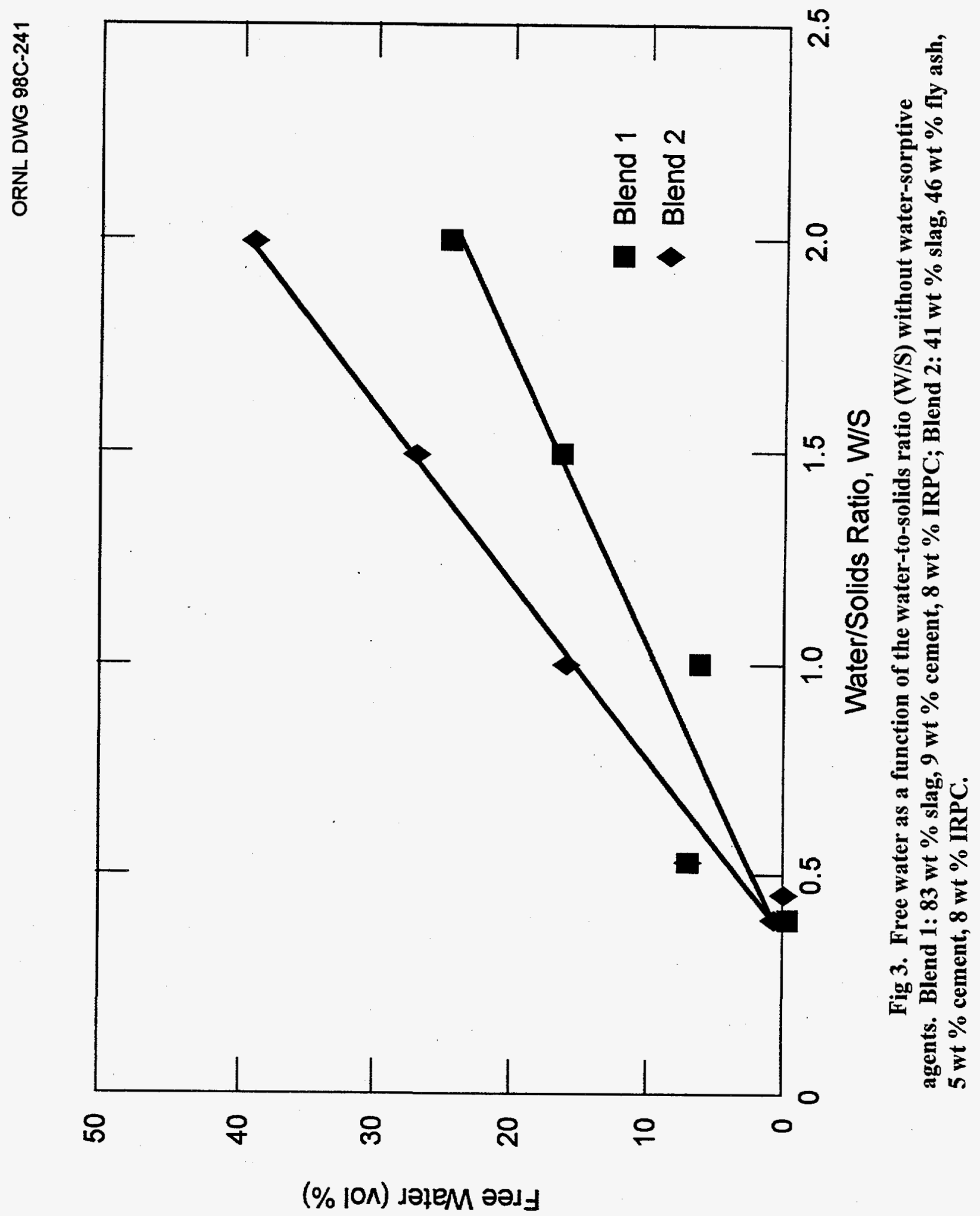




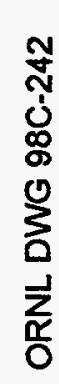

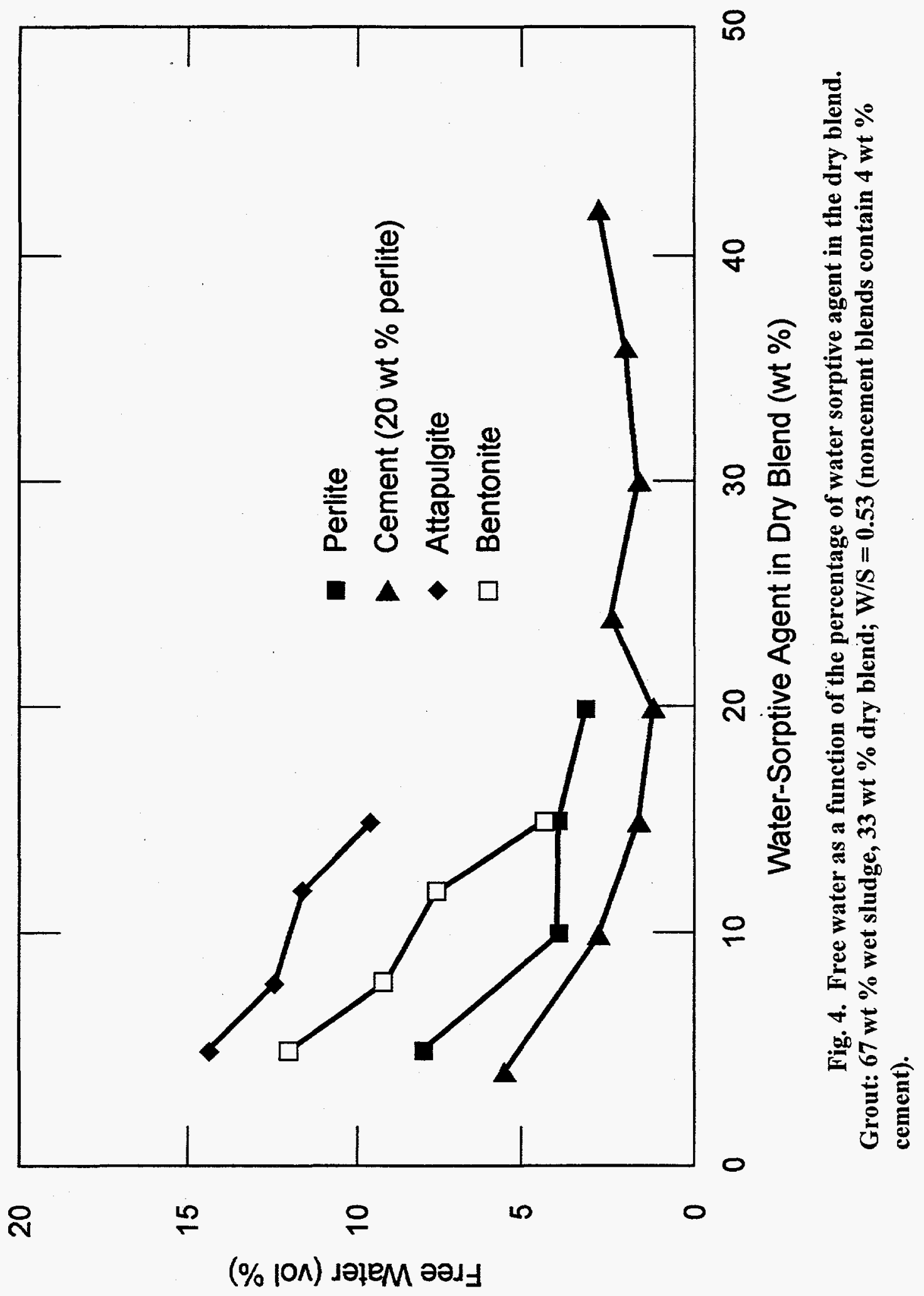




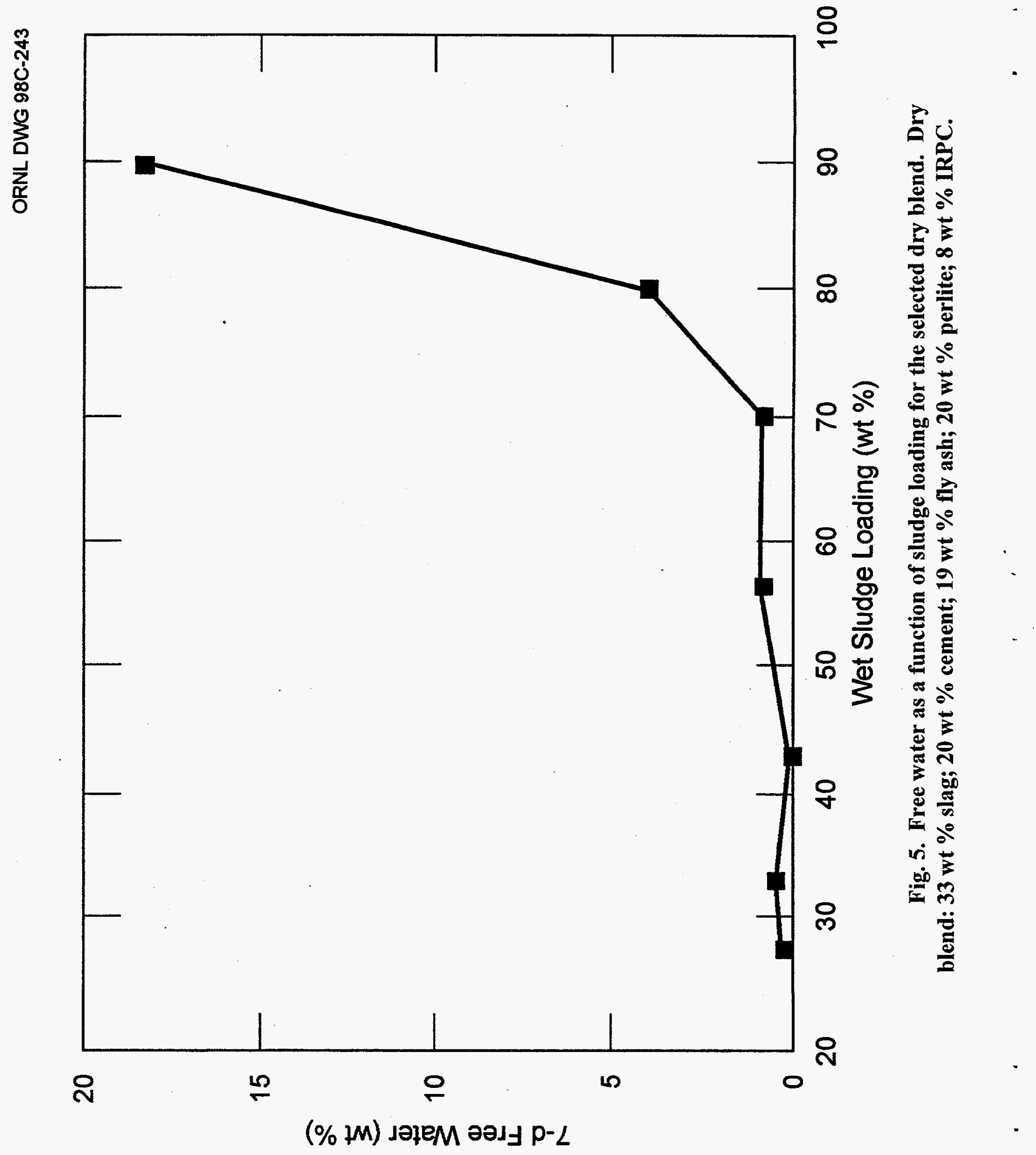




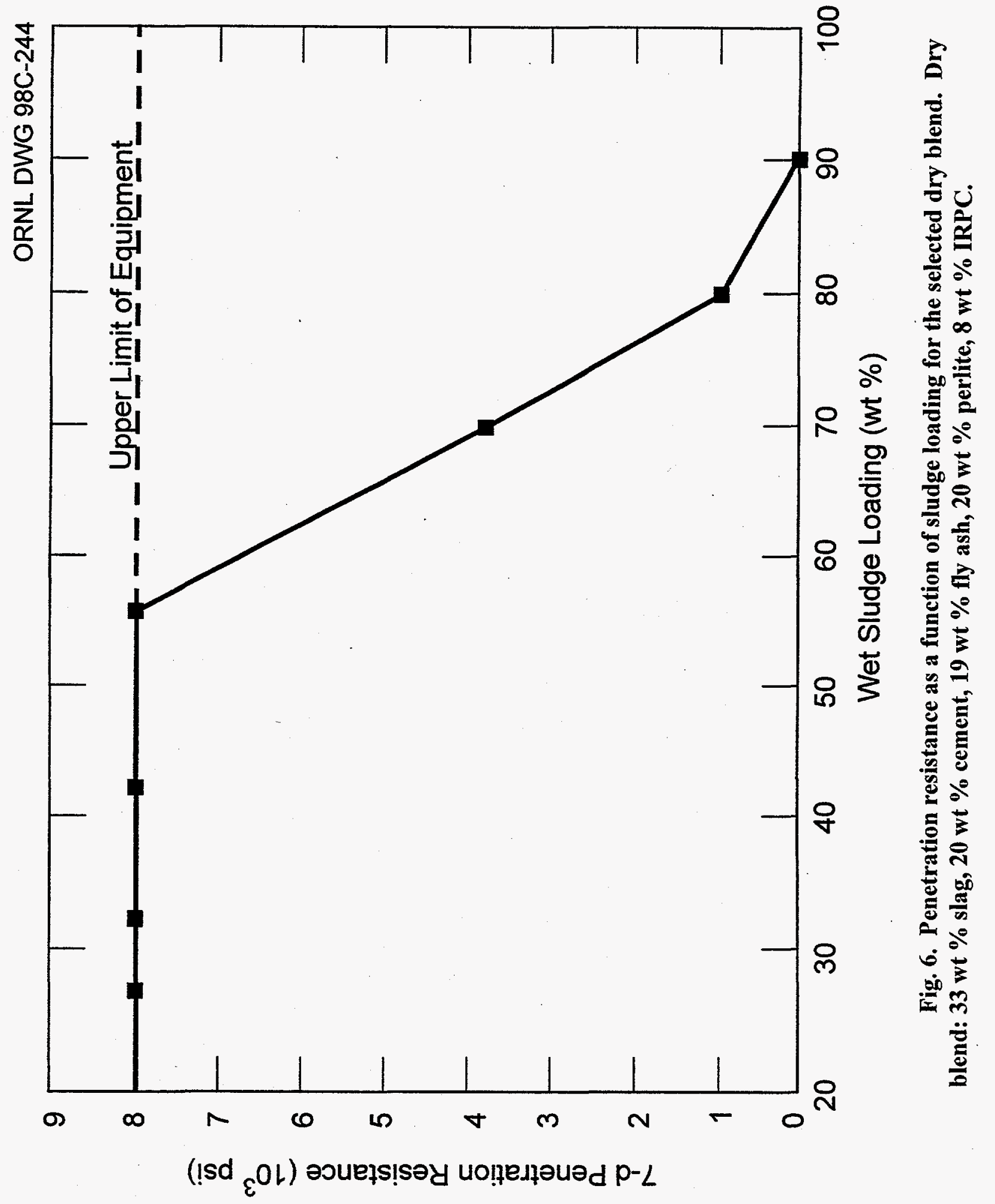


grouts did exceed the limit set by UTS (although the extract selenium concentration never exceeded $0.5 \mathrm{mg} / \mathrm{L}$ ). The later grouts do meet all of the UTS criteria, including selenium. More importantly, the UTS criteria was met for all of the last seven grouts testing the selected standard dry blend, including a wet sludge loading of $90 \mathrm{wt} \%$. The consistently low concentrations of the RCRA metals did not exhibit any obvious correlations, but the extract uranium concentration varied with final extract $\mathrm{pH}$, as illustrated in Fig. 7. Four data points at low $\mathrm{pH}$ (for grouts 29-32) are obvious outliers in Fig. 7. Since these grouts were made with more cement than the other grouts in the scoping tests, it makes no sense that the final TCLP extract $\mathrm{pH}$ would be as low as 5-6. Apparently, the reported extract $\mathrm{pHs}$ for these four grouts are in error.

\subsubsection{Sensitivity Testing}

Sensitivity testing is the evaluation of the sensitivity of a selected formulation to changes in waste composition and changes in concentration of the grout composition. Two grouts were selected for sensitivity testing: (1) to obtain the highest sludge loading and (2) to pass the NRC criteria. For the high sludge loading grout, the dry blend most successful at handling the free water in the scoping tests was 33,20,19,20, and $20 \mathrm{wt} \%$ of slag, cement, fly ash, perlite, and IRPC, respectively. This dry blend was limited to a sludge loading of $55 \mathrm{wt} \%$, because of the free water criteria. To better meet the NRC criteria, the sludge loading for the second grout was reduced to $40 \mathrm{wt} \%$. At this waste loading, the enhanced water sorptive properties were not needed (in fact, some supernate was added to ensure processability), so the dry blend was altered to $41,5,46$, and $8 \mathrm{wt} \%$ of slag, cement, fly ash, and IRPC, respectively. The standard grout compositions resulting from these two formulations are listed as Grout \#1 for the high and low sludge loading in Table 11. In addition, Table 11 lists the four grouts selected for sensitivity testing of variation in the grout composition, taken from the $\pm 10 \%$ variation in the formulation. The sensitivity testing consisted of measuring the performance of the grouts listed in Table 11 using the standard surrogate MVST sludge plus testing each Grout \#1 with surrogate MVST sludge at the maximum water content listed in Table 1 and with surrogate MVST sludge at the minimum water content and the maximum concentration of bad actors listed in Table 1. Table 12 lists the three surrogate sludge compositions used in the sensitivity testing.

Tables 13-17 list the results for the sensitivity testing of the grouts, grout density and grout volume to sludge volume, free water, unconfined compressive strength, TCLP performance and cesium and strontium leachability indexes, respectively.

The high waste loading grout had a volume increase of $44 \%$, no free water, an average compressive strength of $1663 \mathrm{psi}$, an acceptable TCLP performance, and cesium and strontium leachability indexes $>9$. The variation in grout and surrogate composition made the volume increase vary from 36 to $55 \%$. Although the composition variations affected the appearance of free water during cure and the rate at which the free water disappeared, none of the composition variations had any free water after curing $28 \mathrm{~d}$. The composition variations significantly affected the compressive strength, ranging from 776 to $2,086 \mathrm{psi}$, but all were significantly $>500$ psi (the target for the NRC criteria). The composition variations had little effect on the TCLP 


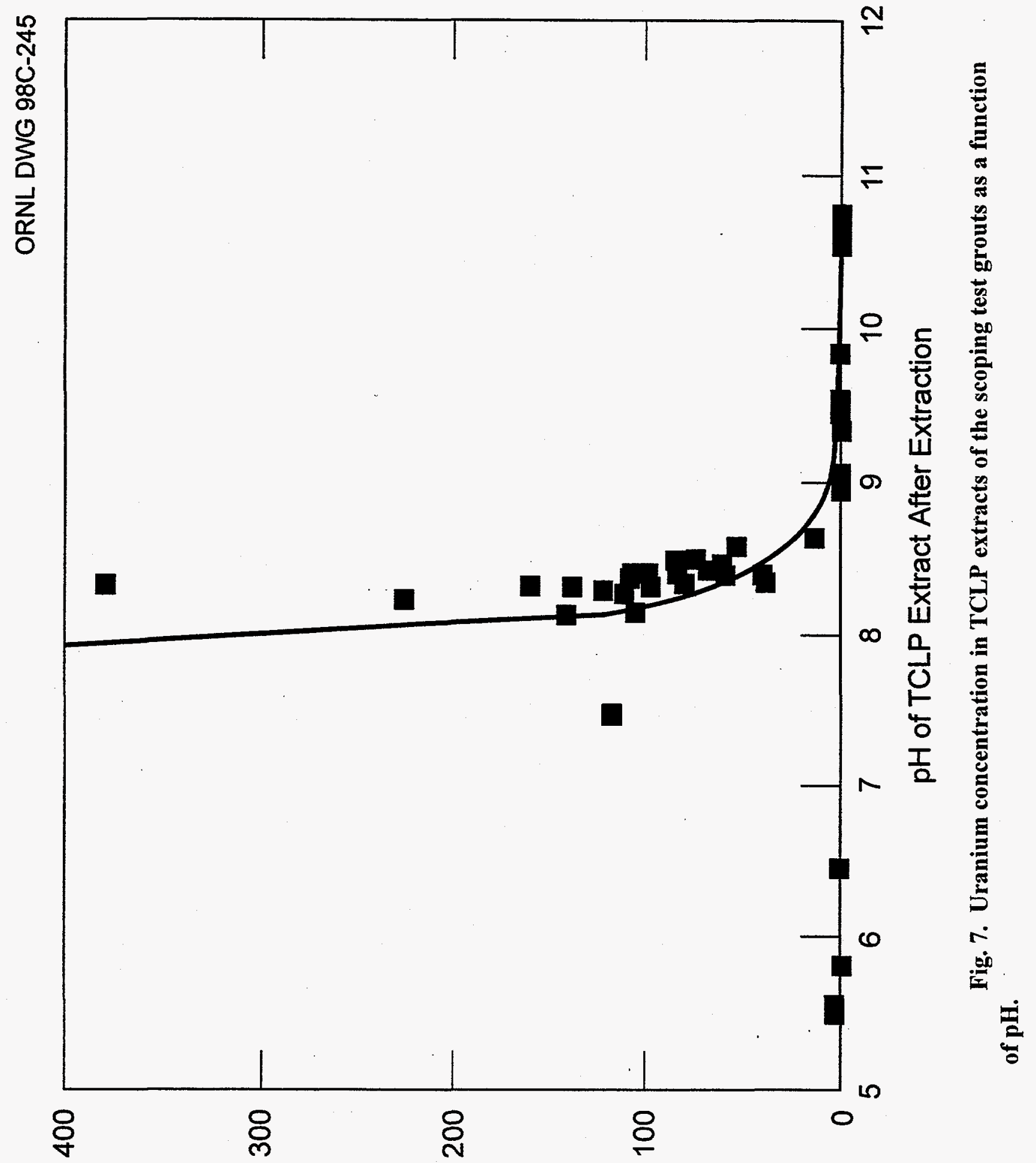

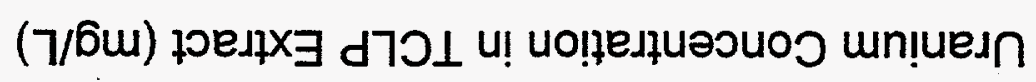


performance or leachability indexes, and all extract concentrations were below the limiting values for RCRA characteristically hazardous, TCLP LDR, or UTS.

The low waste loading grout had a volume increase of $93 \%$, no free water, an average compressive strength of $542 \mathrm{psi}$, and cesium and strontium leachability indexes $>8$. The TCLP performance was acceptable, except the selenium extract concentration exceeded the UTS limit. The variation in grout and surrogate composition made the volume increase vary from 57 to $111 \%$. Although the composition variations affected the appearance of free water during cure and the rate at which the free water disappeared, none of the composition variations had any free water after curing $28 \mathrm{~d}$. The composition variations significantly affected the compressive strength, ranging from 179 to $1888 \mathrm{psi}$, ranging around $500 \mathrm{psi}$ (the target for the NRC criteria). The composition variations had little effect on the TCLP performance or leachability indexes, and all extract concentrations were below the limiting values for RCRA characteristically hazardous, TCLP LDR, or UTS (except the one selenium value exceeding the UTS limit).

Substituting the zeolite sorptive agent used to remove ${ }^{137} \mathrm{Cs}$ from tank supernates for the IRPC in the dry blend decreased the effective diffusion coefficient by one to two orders of magnitude, increasing the leachability index of between 9 and 10 to $>11$ for both ${ }^{137} \mathrm{Cs}$ and ${ }^{85} \mathrm{Sr}$.

In general, the high waste loading grout outperformed the low waste loading grout and is a better candidate for meeting the NRC criteria. The higher cement content in the high waste loading grout or slower activation of slag in the low waste loading grout may explain why the higher waste loading grout is stronger at $28 \mathrm{~d}$, but this has not been definitively established.

Unfortunately, the high waste loading grout was difficult to process and handle, because of its apparent dryness from the water sorption of the perlite. This dry blend may be able to handle wet sludge loadings higher than $55 \mathrm{wt} \%$, without bleed water at $28 \mathrm{~d}$, and the extra water would assist in processing. Field operation with this drier grout (high waste loading) may require some water addition, depending on the mixing and handling equipment and the water content of the sludge being processed.

\section{GLASS}

\subsection{SELECTION OF THE GLASS FORMING SYSTEM FOR FURTHER EVALUATION}

There are numerous glass families that have been developed/evaluated on a commercial scale. Examples of these families include soda-lime-silicate, borosilicate, lead silicate, aluminosilicate, halide, borate, phosphate, sulfide, chalcogenide, chalcohalide, oxyhalide, oxynitride, and oxycarbide glasses. ${ }^{61,62}$ However, of these families, three have received the most attention for the vitrification of wastes. Consequently, these three families, borosilicate, soda-lime-silica (SLS), and phosphate, were the initial candidates for further study within this project . Many phosphate glasses are known to be readily attacked by water ${ }^{62}$ and were quickly discarded as a candidate for further study. Borosilicate glasses, which have been used extensively for immobilization of high-level radioactive wastes, have a large known immiscibility gap in the 
$\mathrm{CaO}-\mathrm{B}_{2} \mathrm{O}_{3}-\mathrm{SiO}_{2}$ system, ${ }^{63}$ and a high calcium content is a characteristic of the waste in this study. The known immiscibility leads to the strong probability of multiple glass phases within the resulting vitrified product. The unknown distribution coefficients of the contaminants of interest (both radionuclides and the RCRA metals) makes a multiple phase product undesirable. Consequently, the experimental study, presented herein, focused on the SLS system. The SLS system has been evaluated previously for numerous low-level radioactive and chemically hazardous (i.e., mixed) waste sludges ${ }^{64,65}$ and has the advantage of utilizing the calcium content of the waste as a needed additive.

\subsection{SELECTING GLASS COMPOSITION REGION FOR EVALUATION}

A methodology for calculating the maximum composition range for formation of acceptable glass products has been developed previously. ${ }^{66} \mathrm{~A}$ brief summary of the rationale for the methodology is presented, herein, for continuity.

\subsubsection{The Basic System}

The phase diagrams for the basic SLS system, those of the related ternary systems that contain common major waste constituents [e.g., alumina $\left(\mathrm{Al}_{2} \mathrm{O}_{3}\right)$ ], and the accompanying literature permit useful comparisons to be made between the conditions of composition and temperature for equilibrium systems and those used to vitrify mixed waste. These comparisons lead, in turn, to an understanding of the fundamental chemical issues that operate in the processing of these wastes.

The structures of silicate glasses are based on the polymerizing tendency of $\mathrm{SiO}_{4}$ tetrahedra, which results, in part, from the bonding properties of Si(IV) and the small ionic size of silicon relative to that of oxygen. For present purposes, the bonding properties have been deemed to rely primarily on the electronic polarity of the $\mathrm{Si}-\mathrm{O}$ bond and the coordination number of oxygen atoms that surround the silicon atoms. Based on electronegativity values, ${ }^{67}$ the Si-O bond is approximately $88 \%$ ionic, indicating that the bond exhibits both ionic and covalent properties.

The $12 \%$ covalent character helps to maintain the tetrahedra in the melt, making them the basic "building blocks" in silicate melts and glasses. If crystalline silicates precipitate from the melt, the high ionicity leads to the well-known variety of crystallographic packing arrangements for $\mathrm{Si}^{4+}$ and $\mathrm{O}^{2-}$.

These concepts indicate that both the melt and its corresponding glassy state can be considered as differing only moderately from the crystalline silicates that possess similar chemical composition. Consequently, an improved understanding of silicate waste glasses can be gained from knowledge of the glass melt, the corresponding crystalline metal silicates, and the solidified glasses. Analogously, the structural properties of glasses that contain elements such as aluminum and boron would respectively resemble the corresponding crystalline aluminosilicates and borosilicates. 
One molecular restriction that applies to the glassy and crystalline states of silicate materials and to their melts is particularly noteworthy. Neighboring tetrahedra that are linked to one another can share only corners; sides and faces of tetrahedra cannot be shared. Hence, two tetrahedra are linked to each other by the sharing of an oxygen atom. This arrangement means that a tetrahedral unit may be linked to two, three, or four other tetrahedra. Two such links per silicon yield, locally and on the average if they predominate, a somewhat linear polymer or chain of $\mathrm{SiO}_{4}$ tetrahedra. Analogously, three bridging oxygens per silicon produce two-dimensional arrays that resemble cross-linked polymers, and four would generate a three-dimensional network.

Clearly, the oxygen-to-silicon ratio is an important parameter for the polymeric and network structures in silicate melts, their corresponding glasses, and the formation of the various crystalline phases that can precipitate during processing. This ratio is $2: 1$ for unary $\mathrm{SiO}_{2}$ systems. Thus, crystalline $\mathrm{SiO}_{2}$ (e.g., quartz) can be understood as composed of tetrahedral arrangements of close-packed ions; this situation explains the relatively high density of quartz. The ionic radii of silicon and oxygen are $0.041 \mathrm{~nm}$ and $0.138 \mathrm{~nm}$, respectively. Hence, the corresponding size ratio for $\mathrm{Si}: \mathrm{O}$ of $0.34: 1$ leads to the establishment or retention of the $\mathrm{SiO}_{4}$ tetrahedra in the crystalline state: $2.65 \mathrm{~kg} \mathrm{~m}^{-3}$, as compared with that of the high-temperature crystalline forms of $\mathrm{SiO}_{2}$-tridymite $\left(2.26 \mathrm{~kg} \mathrm{~m}^{-3}\right)$, cristobalite $\left(2.32 \mathrm{~kg} \mathrm{~m}^{-3}\right)$, and amorphous silica $\left(2.2 \mathrm{~kg} \mathrm{~m}^{-3}\right)$.

These considerations suggest that the establishment of $\mathrm{SiO}_{4}$ tetrahedra in a melt requires an additional source of oxygen in order to achieve the oxygen-to-silicon ratio needed to stabilize the two- and three-dimensional networks. Normally, alkali and alkaline oxides are used to provide the needed oxygen while maintaining charge balance between positive and negative ions. Oxides of other metals, such as the transition metals and some of those in Groups IIIB and IVB, can also be used. This function underscores the variety of silicate minerals and the prevalence of complex compositions for tailored glasses and ceramics.

\subsubsection{Minimum Bridging Oxygens}

Recognizing that the number of bridging oxygens (oxygens which can bond covalently to produce the glass structure) is a critical parameter (above and beyond the simple oxygen-to-silica ratio) suggests a methodology by which one of the boundaries to the range of acceptable compositions can be predicted. The methodology is based upon Stevels ${ }^{68-70}$ theory in which he calculated the mean possible number of bridging oxygens per $\mathrm{SiO}_{2}$ based upon the oxygen-tosilica ratio. A minimum of one bridging oxygen is necessary for a plausible glass structure to form; ${ }^{63}$ that is, at calculated bridging oxygens of less than one, ionic bonding is favored over covalent bonding. Consequently, there is, in effect, too much oxygen to promote the formation 
of the basic tetrahedral structure necessary for glass to form. Thus, the region of acceptable glass compositions would be predicted to be bounded by

where

$$
F=8-2(\text { oxygen/silicon), }
$$

$F \quad=\quad$ the mean possible number of bridging oxygens and has a value $\geq 1$,

oxygen $=$ moles of oxygen within the glass melt,

silicon $=$ moles of silicon within the glass melt.

\subsubsection{Waste Composition on an Oxide Basis}

The equation for bridging oxygens can be used to predict a region of acceptable glass formulations based upon the composition of the waste being vitrified. The waste composition has been described previously (Sect. 3). However, the chemistry of glass formation takes place at elevated temperatures $\left(>1000^{\circ} \mathrm{C}\right)$. Consequently, the waste is assumed to be calcined prior to the chemistry of glass formation taking place. This, in turn, leads to the chemistry of glass formation being more appropriately described on an oxide basis rather than an "as received" basis. Toward that end, the dried waste composition was calculated assuming that the majority of the constituents are converted to oxide form. The calculated composition of the dry waste on an oxide basis is shown in Table 18.

It should be noted that the summation of the resulting oxides represents approximately $475 \mathrm{~g} / \mathrm{kg}$ of original dried waste. Thus, the conversion to oxide form or calcination of the waste leads to a significant reduction in the quantity of waste to be immobilized in the glass as compared with the original weight of the waste. The weight loss of the dried surrogate is primarily due to the thermal destruction of the nitrates and would be transferred to the off-gas treatment system of a melter.

\subsubsection{The Operating Diagram}

Historically, the SLS system has used the three-component operating diagram with units of weight percent to illustrate regions of acceptable glass formulations. However, it is well known that the chemistry of any system occurs on a mole basis rather than a weight basis. The primary reason that units of weight percent can successfully illustrate regions within the SLS system is that the molecular weights of the three components are so similar. The molecular weights of $\mathrm{Na}_{2} \mathrm{O}, \mathrm{CaO}$, and $\mathrm{SiO}_{2}$ are 62,56 , and $60 \mathrm{~g} /$ mole, respectively. Thus, a plot of composition in weight percent would accurately (to within a few percent error) reflect composition in mole percent. Obviously, as more components are introduced into the system, this comparison is no longer as accurate as the simple three-component system. Nonetheless, the operating diagram has proven to be an acceptable means of describing glass formulations containing mixed ${ }^{64.66}$ and is used herein. 
The surrogate waste composition (on an oxide basis) is shown in the traditional ternary operating diagram in Fig. 8. The "three" components represented on the diagram include alkalis (e.g., $\mathrm{Na}_{2} \mathrm{O}$ ), alkaline earths (e.g., $\mathrm{CaO}$ ), and glass formers $\left(\mathrm{SiO}_{2}\right.$ and $\left.\mathrm{Al}_{2} \mathrm{O}_{3}\right)$. Line A-A represents calculated bridging oxygens of $\approx 1$. Thus, line $\mathrm{A}-\mathrm{A}$ is one of the boundaries of acceptable glass compositions and, in effect, represents the maximum allowable oxygen content in the melt for this application. Compositions to the right of line A-A are those with calculated $F$ values greater than 1. The second boundary for acceptable glass compositions, also shown in Fig. 8, is line B-B. Line B-B is particularly noteworthy in that it represents a suspected phase-separation boundary based upon literature data for the $\mathrm{CaO}-\mathrm{Na}_{2} \mathrm{O}-\mathrm{SiO}_{2}$ system; ${ }^{71}$ that is, compositions beyond this boundary that are "deficient" in alkali and alkaline earth tend to form unary rather than ternary phases. Compositions to the right of line B-B would be expected to produce glass products characterized by phase separation and/or contained crystalline material. Line C-C represents the maximum alkaline earth $(\mathrm{RO})$ composition supplied by the waste. One of the constraints imposed is the assumption that the waste supplies one of the major SLS glassforming system components, thus necessitating only two additional additives. The resulting region bounded by lines A-A, B-B, and C-C represents the predicted region of acceptable compositions. The recipes or formulations for further evaluation are those additives which when combined with the waste result in compositions within the bounded region.

It is interesting to note that the line A-A, representing a minimum bridging oxygen of $\sim 1$, corresponds to a waste loading of approximately $50 \mathrm{wt} \%$ (on an oxide basis). Therefore, for this glass-forming system and surrogate composition a waste loading of $50 \mathrm{wt} \%$ represents the maximum achievable waste loading.

\subsection{EXPERIMENTAL PROCEDURE}

The aqueous surrogate MVST sludge was prepared as described in Sect. 4.1.1. The sludge was then dried at $105^{\circ} \mathrm{C}$ to a constant weight. The dried material was broken up with a hammer, followed by ballmilling for approximately $2 \mathrm{~h}$. This dried, size-reduced material was passed through a $4.75-\mathrm{mm}$ sieve. It is this dried, homogenized, and sieved material that became the waste feed for the vitrification studies.

Weight loss observed upon drying was $52.4 \mathrm{wt} \%$ (the water content, including waters of hydration, of the surrogate sludge was $52.0 \mathrm{wt} \%$ ). Homogenization of the dried material proved difficult due to the presence of a hard white crust on the upper surface of the dried waste. This white crust was determined to be $\mathrm{CaCO}_{3}$.

A more detailed discussion of the procedures in preparing glass is presented elsewhere..$^{65} \mathrm{~A}$ brief summary of the procedure follows. The recipe of interest was selected from the predicted composition region, as described in Sect. 5.2.4. The ingredients were weighed, combined, and rolled in a ball mill for approximately $30 \mathrm{~min}$. The material was then placed in a $99.8 \%$ pure alpha- $\mathrm{Al}_{2} \mathrm{O}_{3}$ crucible with a loose fitting lid. The crucible and contents were placed in a hightemperature furnace to achieve melting. The furnace was programmed to ramp to the desired - melt temperature at $300^{\circ} \mathrm{C} / \mathrm{h}$ and hold at the melt temperature for $4 \mathrm{~h}$, after which the fluid glass 


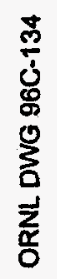
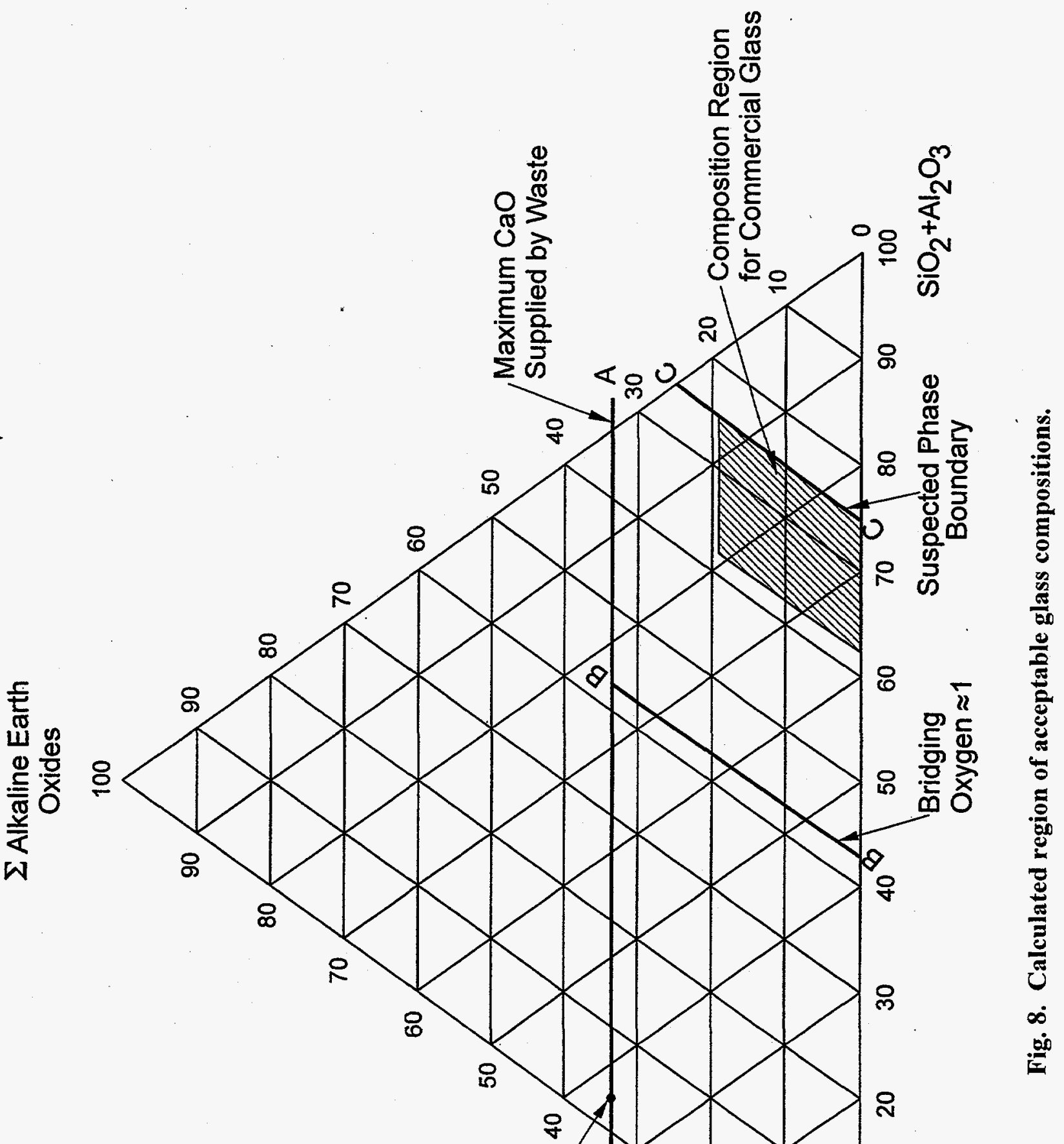
was poured into a stainless steal pan and allowed to cool to ambient temperature. The resulting solidified glass product was then subjected to various characterization/analyses.

\subsection{RESULTS AND DISCUSSION}

\subsubsection{Scoping Tests}

Glass recipes/formulations evaluated in the scoping tests and calculated composition of the resulting products are presented in Table 19. The glass-product compositions are also shown on the traditional ternary diagram in Fig. 9.

\subsubsection{Viscosity}

All glasses poured easily from the crucible, indicating that removal of the glass from field-scale operations does not appear to be an issue of concern. Viscosity determinations (other than by visual observation) were beyond the scope of this project. However, glass viscosity models have been developed and can be used to qualitatively calculate the viscosity of the glass produced. $[72,73]$

\subsubsection{Leaching}

All glasses were subjected to TCLP testing. Results are presented in Table 20. As shown by these data, all products were acceptable with respect to meeting RCRA LDR per this test. That is, none of the glasses produced would be designated as characteristically hazardous for $\mathrm{Ag}, \mathrm{As}$, $\mathrm{Ba}, \mathrm{Cd}, \mathrm{Cr}, \mathrm{Pb}$, or $\mathrm{Se}$. Thus, it is assumed that glasses with compositions within the region bounded by compositions from experiments numbered $\mathrm{V}-1, \mathrm{~V}-5, \mathrm{~V}-\dot{6}$, and $\mathrm{V}-8$ would produce products with acceptable TCLP values.

The question of "what constitutes good leaching performance" has been debated for decades. Numerous leach tests and acceptance criteria have been put forward. ${ }^{74}$ The most widely used is ANS 16.1, and leach results for this test are presented in Sect. 5.1.2. It is widely recognized that leaching (or the release of constituents in a liquid environment) is a complex process which is impacted by leachant composition, available solid surface area, matrix composition, constituent speciation, anion associated with the constituent (i.e., chemical form of the constituent), soluble fraction of the constituent, etc. Nonetheless it is the TCLP that is the standard applied under RCRA. As stated previously, all glasses produced acceptable TCLP results as defined by regulation. However, within this region of glass composition, TCLP concentrations actually varied significantly. For example, uranium leachate concentrations ranged from 0.039 to 8.5 $\mathrm{mg} / \mathrm{L}$. Clearly, the TCLP, which is used to determine acceptable glass from a regulatory context, is not sufficient to identify and explain significant leaching differences at leachate concentrations below the regulatory threshold value.

Be that as it may, the TCLP leach values can be used to identify qualitative trends with respect to TCLP leachate values versus glass composition. Experiments V-1 through V-5 represent glass 


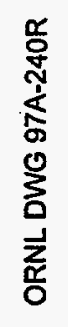

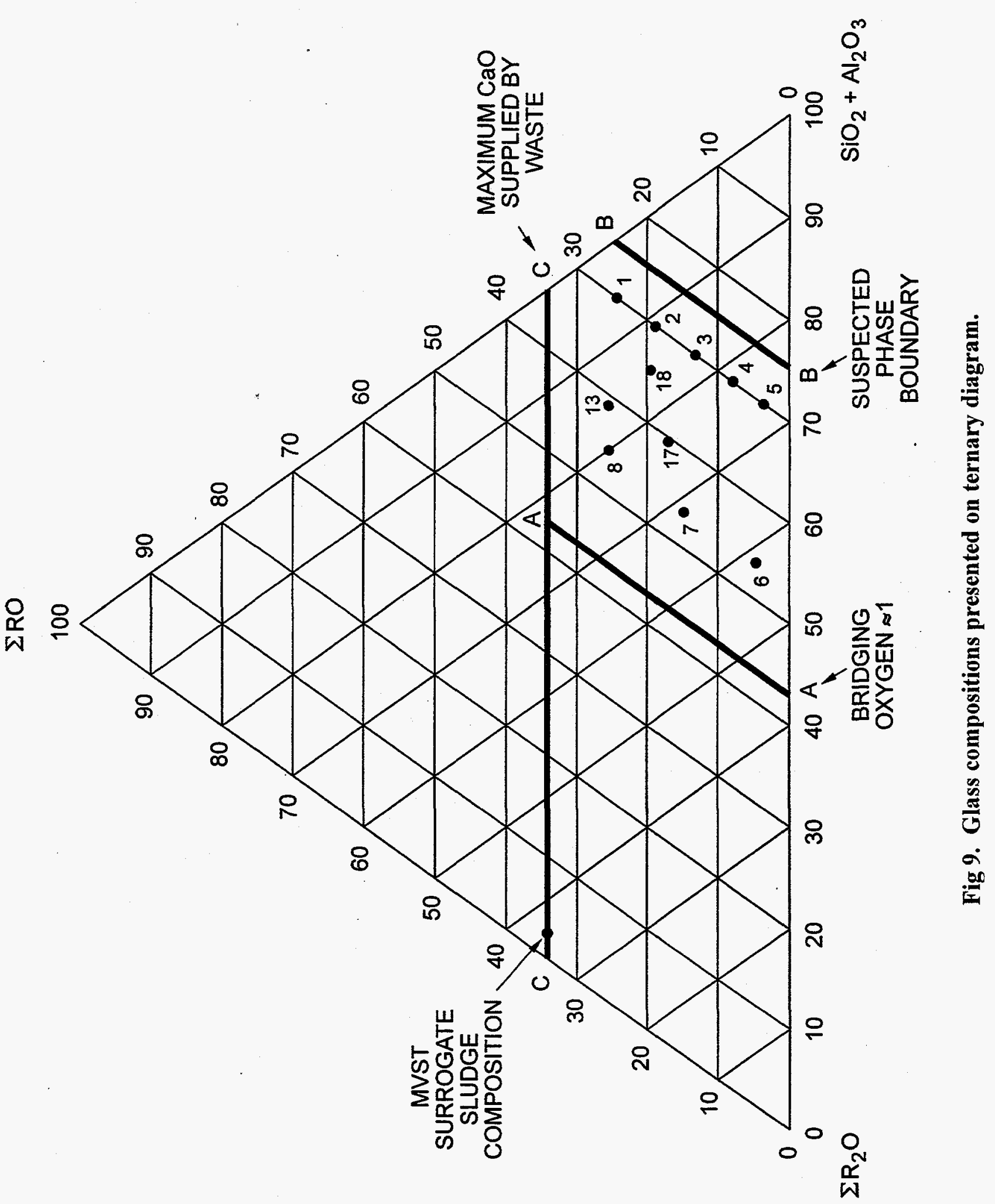


compositions with an approximately constant waste loading and silica content (70 wt \%). The basic change in composition is that the $\mathrm{CaO}$ content is reduced with a corresponding increase in $\mathrm{Na}_{2} \mathrm{O}$ content as the experiment number is increased from V-1 to V-5. As one would expect, the calcium leachate concentrations decreased as the calcium content of the glass decreased, as did the sodium. However, the potassium TCLP concentration steadily increased as the glass calcium content decreased, indicating that there may be a minimum calcium-to-sodium ratio necessary to significantly reduce leaching.

Runs V-6, V-7, and V-8 represent a similar series of runs with a constant silica content of approximately $55 \mathrm{wt} \%$. Leachate concentrations were generally higher for all constituents for glass compositions with 70 wt \% silica. Clearly silica, which is the basic building block of the glass structure, is beneficial. It should be pointed out, however, that the line representing a silica content of $55 \mathrm{wt} \%$ corresponds to the compositions where calculated bridging oxygens are constant at 2 . At bridging oxygens of 2 , the basic glass structure changes from group silicates to ring or chain silicates. ${ }^{75}$ As bridging oxygens are increased, the structure further changes to layer silicates and ultimately network silicates. In simplest terms, as the number of bridging oxygens increase, so does the bonding between the various silicate building blocks, thus producing a stronger glass matrix which should offer greater leach (or release) resistance. It is this trend with bridging oxygens which best describes the observed TCLP data.

\subsubsection{Material Characterization}

Typically, a performance criterion for acceptable glass product is that it be amorphous. That is, no observable secondary phases. Devitrification (the formation of crystalline phases) during or within the melt process is unacceptable. The crystals formed can plug material transfer lines (or drains) and in some cases the melter itself. It should be noted that formation of crystals during the cooling process (assuming that cooling takes place external to the melter) is not necessarily detrimental and may actually improve leach performance. ${ }^{65}$

In the compositional studies presented herein, it is assumed that the method of pouring glass into a steel pan at ambient conditions provides sufficient cooling to avoid the formation of crystalline phases during the cooling process. Therefore, any observed crystallinity in the glass product is considered to be formed during the melt process and constitutes an unacceptable glass. Toward that end, product samples were submitted for X-ray Diffraction (XRD) characterization.

$\mathrm{XRD}$ is a method for determining the presence and identity of the crystalline components of the glass product. The basic technique involves the bombarding of a crystal with a monochromatic beam of X-rays. Under these conditions, there exist a limited number of angles at which constructive diffraction occurs, and when a detector is moved past the cones of diffracted X-rays, a series of peaks is observed. The positions of these peaks are characteristic of individual crystalline compounds within the glass sample. An absence of peaks is indicative of an amorphous or glassy material. 
Figures 10,11, and 12 illustrate typical diffraction patterns of glasses that (by XRD) are deemed amorphous, slightly crystalline, and strongly crystalline. All glasses evaluated in this study were deemed amorphous via XRD.

\subsubsection{Appearance of Glass Above the Melt Line}

Recorded visual observations during the pouring of the glasses made during the scouting studies (Sect. 5.4.1) are presented in Table 19. In some cases, the glass was observed to have traveled up the crucible walls during the melting process. The presence of this thin layer, possibly indicating that foaming had occurred, could prove corrosive to melter components during actual full-scale operations. In essence, the glass is of low viscosity and can penetrate into the microcracks of the melter liner. This fluid melt is highly corrosive and can accelerate liner corrosion by this penetration. Consequently, it can significantly reduce the lifetime of a melter liner, thereby increasing cost and reducing operating time, and, in the worst case, present a safety hazard by corroding through the melter and allowing molten glass to flow out into the working environment. Unfortunately, there is little if any data on the increased rate of corrosion induced by this phenomenon.

It is significant to note that this phenomenon was observed for glass compositions with the highest waste loading. The high waste loading corresponds to glass melts with the highest nitrate content. Nitrates are known oxidants. Initially, it was assumed that the dominant decomposition products of the nitrate would be $\mathrm{NO}_{2}$ and $\mathrm{O}$, with the $\mathrm{O}$ combining with the cation to form its oxide. However, literature data have confirmed that to some extent the decomposition products are $\mathrm{N}_{2}$ and $\mathrm{O}_{2}$, as described by Volf and presented in Eqs. (2) and (3). ${ }^{63}$

$$
\begin{aligned}
& 2 \mathrm{NaNO}_{3} \rightarrow 2 \mathrm{NaNO}_{2}+\mathrm{O}_{2} \\
& 4 \mathrm{NaNO}_{2} \rightarrow 2 \mathrm{Na}_{2} \mathrm{O}+2 \mathrm{~N}_{2}+3 \mathrm{O}_{2}
\end{aligned}
$$

The results of these decomposition reactions are twofold. First, these reactions indicate the presence of more gas generation than anticipated from the nitrate salts. This "excess" of gas bubbling through the melt could lead to a lower melt viscosity than anticipated, and its release (escape) at the melt line could induce foaming.

Second, the presence of this "excess" oxygen suggests that the melt chemistry takes place in the presence of more oxygen than envisioned in the bridging model used to calculate the expected range of acceptable compositions. This, in turn, would lead to fewer bridging oxygens to form the cohesive glass structure, producing a less viscous (more fluid) melt. In simplest terms, the basic glass building block is the ionic bond between silicon ( $\mathrm{Si}$ ) and oxygen $(\mathrm{O})$. The bridging oxygens, which connect the building blocks to form a durable structure, do so by covalent bonding between oxygens. In the presence of "excess" oxygen, ionic bonding is favored over covalent bonding and the glass does not form the structure predicted. This "lack of structure" leads to a fluid of lower viscosity than predicted. 


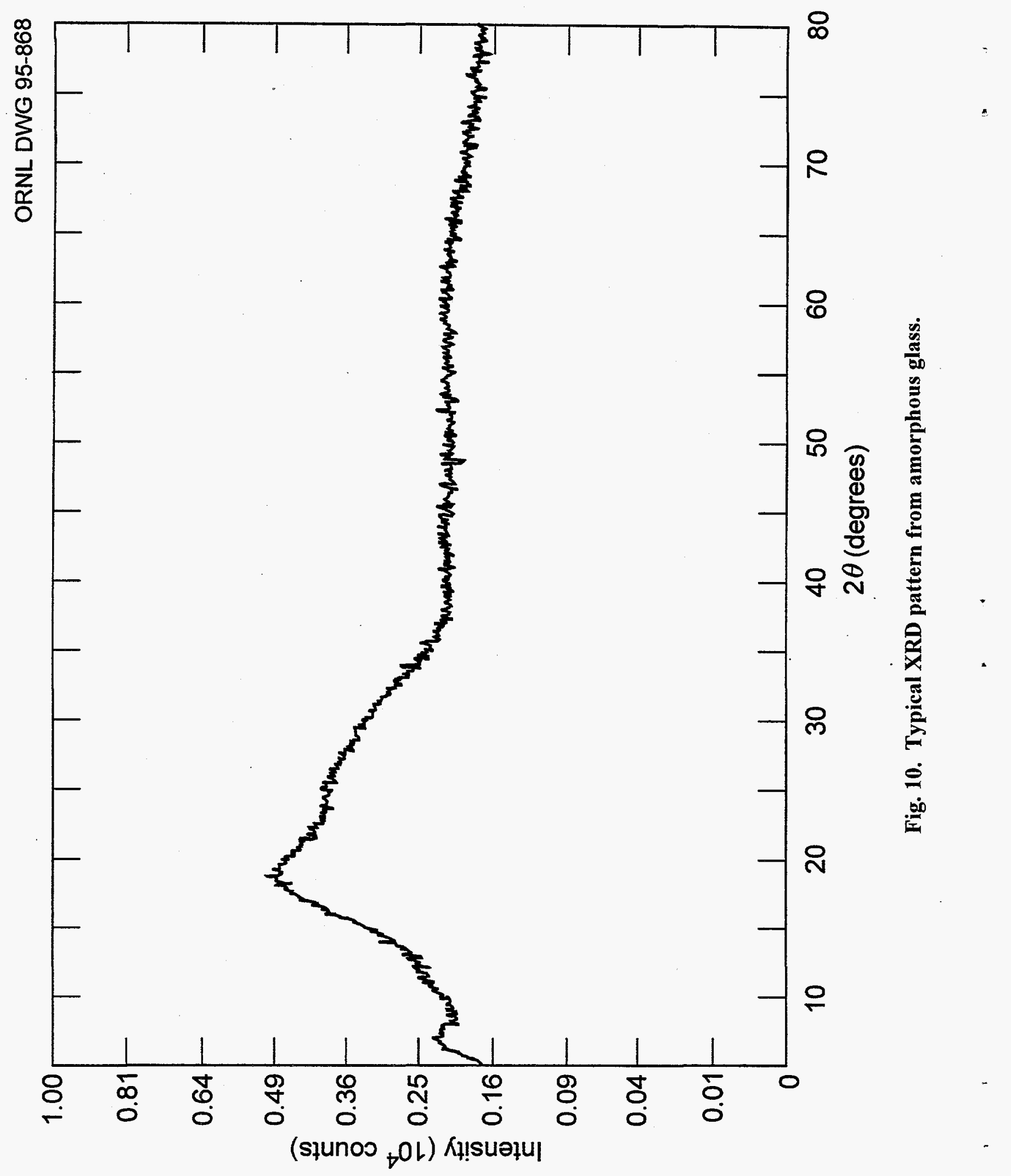




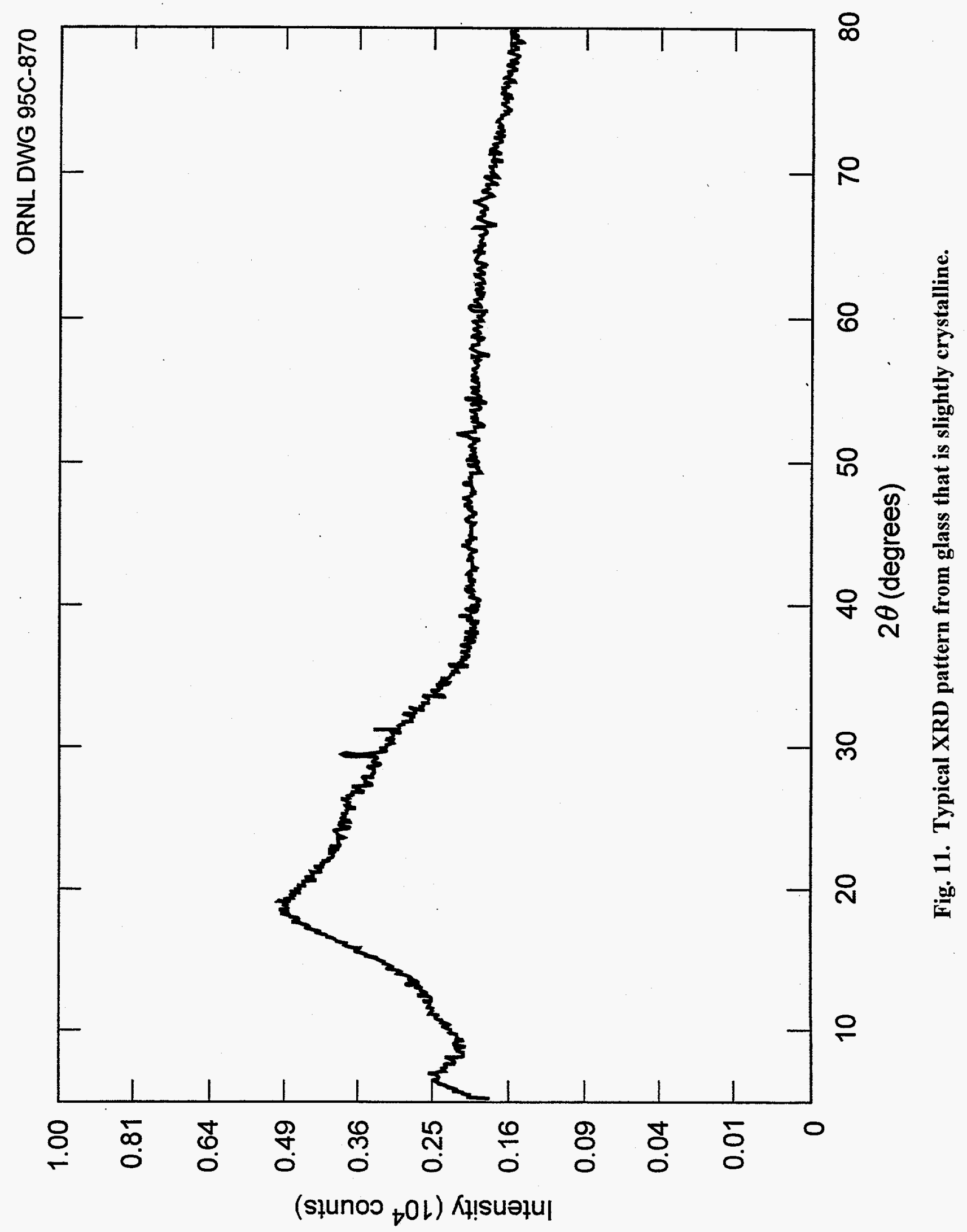




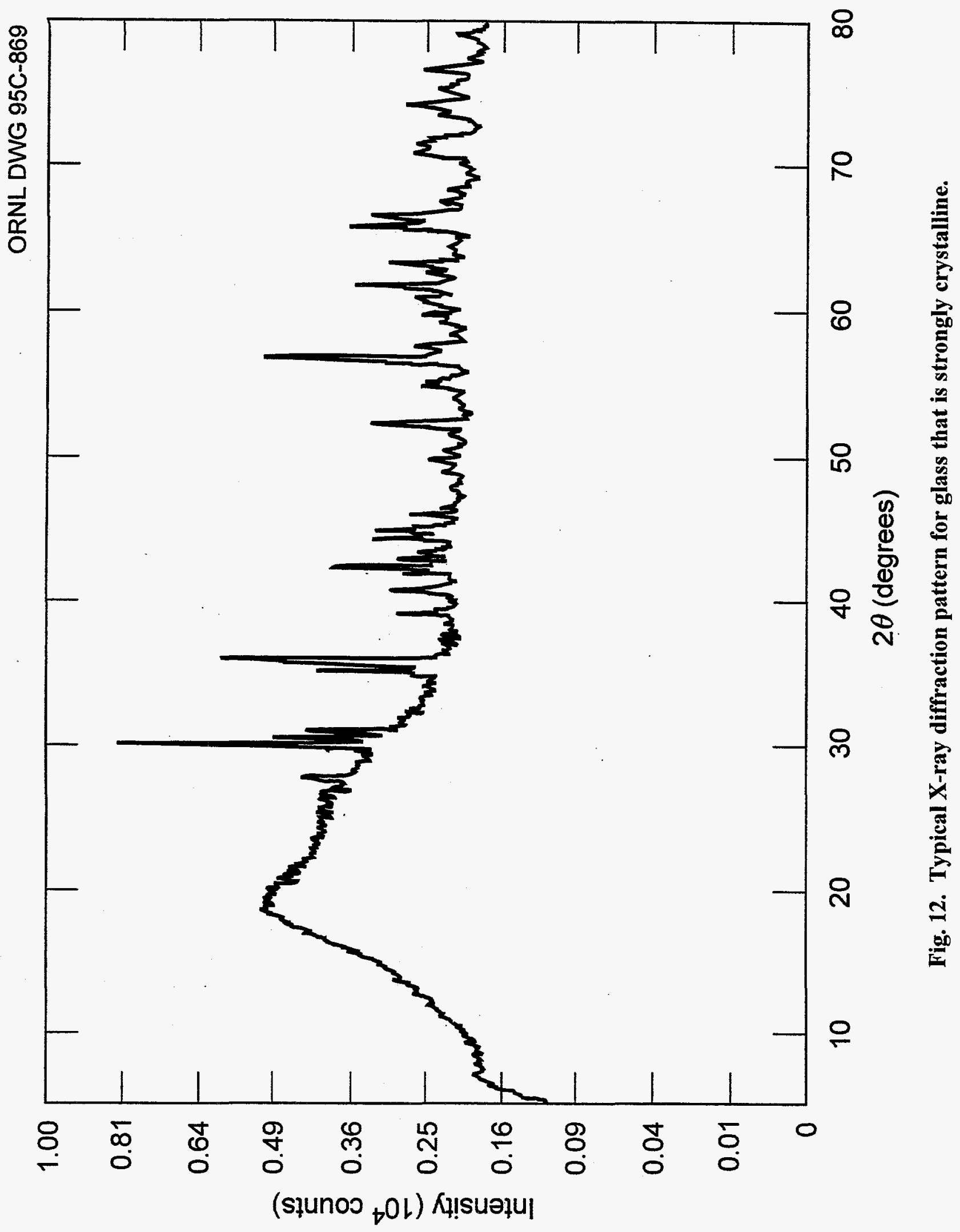


Experience ${ }^{76-80}$ with borosilicate glasses developed for high-level radioactive wastes at Westinghouse Savannah River Company (WSRC) has shown that glass melt chemistry/behavior is a strong function of the oxidation-reduction (redox) equilibria, which is influenced by melt temperature and the presence of oxidizers such as nitrates or oxygen. In some cases, deoxygenation of salts can lead to foaming in waste glass melters, particularly as melt temperature increases. In order to mitigate these concerns, it has been recommended that routine operation of borosilicate glass at a melter temperature of $1150^{\circ} \mathrm{C}$ be performed in melt conditions with oxygen fugacity maintained between $10^{-2}$ and $10^{-9}$ (or percentage of reduced iron between 8 and 80 ). Foaming was observed at higher temperatures with oxygen fugacity as high as $10^{-4}$ (20\% reduced iron).

In order to verify that the melts in the scouting studies were being formed under "extreme" oxidizing conditions, the $\mathrm{Fe}^{2+} / \mathrm{Fe}^{3+}$ redox couple was determined in the glass products. The method used was developed previously by WSRC in support of the high-level nuclear waste vitrification program. ${ }^{76-80}$ In essence, the determination of the $\mathrm{Fe}^{2+} / \mathrm{Fe}^{3+}$ redox couple allows the calculation of the oxygen fugacity of the melt conditions. This, in turn, allows the determination of other inorganic redox couples using available Electromotive Force (EMF) data. The wetchemical technique used to determine the $\mathrm{Fe}^{2+} / \mathrm{Fe}^{3+}$ redox couple is summarized as follows:

- Dissolution of the glass sample in an $\mathrm{H}_{2} \mathrm{SO}_{4} / \mathrm{HF}$ mixture containing ammonium vanadate.

- Addition of boric acid to destroy the iron-fluorine complexes.

- $\quad$ Addition of pH 5 buffer and Ferrozine with subsequent measurement of the magenta-colored ferrous-Ferrozine complex to determine the ferrous iron.

- $\quad$ Addition of ascorbic acid to reduce any ferric iron to ferrous.

- Remeasurement of the total absorbance of the ferrous Ferrozine complex to determine total iron. The difference between the two measurements is taken to be the ferric iron.

Resulting redox data are presented in Table 21. Experiments numbered V-18, -24 , and -25 represent replicates of the same recipe. Although the percent reduced iron for V-24 and V-25 showed excellent consistency (23 and $20 \%$, respectively), V-18 (11\%) did not. The differing values may be attributed to sample heterogeneity, in spite of the efforts taken in sample preparation to achieve a homogeneous product. Conversely, the difference may be attributed to the accuracy/precision of the analytical technique at the low iron concentrations of this surrogate. In either case, comparisons of the relative percentage of reduced iron for the various samples must be assumed to be qualitative indicators rather than absolute values.

In general, the iron redox data indicate oxidizing conditions, with most values of the percentage of reduced iron being in the low 20 s or teens (oxygen fugacity on the order of $10^{-4}$ and higher). Based upon the experience at WSRC, these values would suggest that the melt is too oxidizing 
and conditions are favorable to observe foaming. For want of additional data, the observance of glass on the crucible walls above the melt line will be referred to hereafter as foaming.

The iron redox data indicate that the melts experience "excessive" oxidizing conditions and suggests the need for the addition of a reductant to the melt. The role of the reductant would be to react with the "excess" oxygen, thereby mitigating its effect on the melt chemistry. Numerous reductants are available. In determining the reductant of choice, it is important to understand the chemistry of the nitrate decomposition. Nitrate salts such as $\mathrm{NaNO}_{3}$ and $\mathrm{KNO}_{3}$ melt at temperatures on the order of 300 to $350^{\circ} \mathrm{C}$, which is substantially below the melting point of the primary glass formers in the recipe. Although actual nitrate decomposition occurs over a range of temperatures, it is known to begin slightly above its melting temperature. ${ }^{63}$ Thus, the reduction reaction can and should take place at temperatures significantly below that of the melt temperature (operating temperature in field-scale operations). During field-scale operations, this would indicate that the reducing reaction should take place in the melter working space above the glass melt. The glass melt would be maintained at operating temperatures of 1100 to $1400^{\circ} \mathrm{C}$ (depending on the formulation used), while the working space above the melt would experience a temperature gradient of feed temperature (near ambient) to that of the melt. Consequently, the reduction reaction would need to take place at a temperature on the order of $400^{\circ} \mathrm{C}$ (slightly above the nitrate melt temperature). This would suggest introducing a reductant, perhaps as second feed stream, into the working space above the melt in a regime of the desired temperature $\left(\sim 400^{\circ} \mathrm{C}\right)$. For reactions at this temperature, carbon-containing materials such as sugar appear to be a strong candidate.

\subsubsection{Redox Experiments}

Although redox studies were beyond the scope of this project, three simple experiments were performed in an attempt to assess the effects of carbon addition. Simplified assumptions as to the reduction reaction predict that 1 mole of carbon is needed for each mole of nitrate in the waste. This translates to approximately $5 \mathrm{~g}$ of carbon per $100 \mathrm{~g}$ of dried waste. In an effort to assess the effects of carbon, activated carbon was added to formulation V-9 in various quantities. Specifically, small quantities of activated carbon were placed on top of the V-9 blended ingredients after the ingredients had been placed in the crucible. The layered mixture (carbon on top) was then placed in the furnace and subjected to the normal heating profile described previously. Formulations $V-10, V-11$, and $V-12$ are identical to $V-9$ except that $1.2,1.2$, and $3 \mathrm{~g}$ of carbon, respectively, were added to the V-9 formulation. V-11 was identical to V-10 except that the carbon was blended in with the formulation ingredients rather than placed on top. As shown by the $\mathrm{Fe}^{2+} / \mathrm{Fe}^{3+}$ data in Table 22, there is no indication of the carbon having any effect on the percentage of reduced iron. This lack of effect is attributed to the experimental procedure. That is, ramping to melt temperature at $300^{\circ} \mathrm{C}$ as in the procedure for the routine composition studies is not indicative of conditions to approximate reactions occurring above the melt. Future experiments to assess the effect of carbon on redox should be performed at melt temperature. That is, the furnace should be preheated to melt temperature before placing the crucible in the furnace. It is believed that this would better approximate the heat-up rates actually experienced 
in the working area above the melt in field-scale operations and, thus, more accurately assess the effects of carbon addition.

Clearly the solution to the "excess" oxidizing conditions in the melt is to induce a reduction reaction. The reductant and the quantities needed are yet to be established. However, once established, the operating window or range of formulations which are acceptable should more closely approximate the predicted range (Sect. 5.1.4).

\subsubsection{Sensitivity Testing}

It must be recognized that the scouting studies described previously were not designed to identify an optimum formulation. The present studies have identified a potential problem with several of the glass formulas producing melts with glass adhering to the crucible wall above the melt line. Such a phenomenon could have serious consequences on melter operation at the field scale. As discussed in Sect. 5.4.2, it is believed that the cause of this phenomenon is known and can be overcome, thereby making the majority of the predicted acceptable composition regime available (or acceptable) during actual operations. However, this was not confirmed during this scouting study. Consequently, a recipe/formulation for further additional testing had to be selected from a much smaller region than that predicted. That is, the recipe for additional testing was selected based upon the limited data available and it was not assumed that the potential foaming problems identified with some of the glass formulations could be overcome. Thus, the formulation for additional testing was selected from the composition regime bounded by formulations $\mathrm{V}-1, \mathrm{~V}-3$, $\mathrm{V}-17$, and V-13, which did not exhibit foaming, and was arbitrarily taken to be the composition at the center of this region (i.e., $V-18$ ).

Table 21 lists the feed compositions and the ternary glass compositions for the sensitivity test glasses. The standard glass was tested in triplicate (V-18, V-24, and V-25). Four variations of the $\pm 10 \%$ variations in the feed mix were picked for sensitivity testing (V-19-V-22). The remaining glass (V-23) used the standard glass recipe, but extra RCRA metal compounds were added to the dried sludge to simulate the maximum RCRA metals listed in the tank characterization data. Table 23 lists the solids composition of the standard MVST surrogate sludge used for seven of the eight glasses and the surrogate solids composition with maximum RCRA metals used for V-23. These eight glass melts poured readily into graphite molds. After filling with the melted glass, the graphite molds were placed in a furnace at $535^{\circ} \mathrm{C}$ for $2 \mathrm{~h}$ and then allowed to cool to room temperature in the furnace, to anneal the glass. This procedure resulted in clear glass cylinders for leach testing, tinted slightly green or amber with a cluster of gas bubbles trapped in the center. The cylinders were slightly rounded at the top (the result of the glass melt meniscus when the mold was filled with the viscous glass). The dimensions and masses of the cylinders were measured and used to calculate the glass densities listed in Table 24. Since the cylinders were not perfect right cylinders and contained gas bubbles, the densities listed in Table 24 are bulk densities. These bulk glass densities were used with the estimated volume of wet sludge used in making these glass cylinders and the cylinder masses to calculate the ratios of the resulting glass volume to the original wet sludge volume listed in Table 24. These values imply that one can expect a volume reduction by more than a factor of 
2 upon vitrifying the wet sludge into SLS glass (not counting any off-gas or secondary waste volumes), compared with the volume increase of about $50 \mathrm{vol} \%$, if grouted.

These glass cylinders were leached in deionized water at room temperature. Daily monitoring of the cesium and strontium concentration of one leachate indicated that no measurable concentrations accumulated in the leachates during the first week. After $6.85 \mathrm{~d}$, the leachates were replaced with fresh deionized water and the cesium and strontium concentrations measured in these first leachates. Table 25 lists these leachate concentrations along with the cesium and strontium concentration measured in each glass by total dissolution analysis. Also listed in Table 25 are the percentages of the cesium and strontium spiked into the glass feed mix recovered by total dissolution analysis of the glass product. Some volatilization of cesium was expected, and Table 25 indicates a presence of at least 44 to $57 \mathrm{wt} \%$ of the original cesium in the glass product. However, not all of the unrecovered cesium necessarily vaporized, because some glass may not have dissolved in the total dissolution analysis. As Table 25 illustrates, less than $100 \%$ of the strontium was also recovered (except for V 21 with $122 \%$ recovery), which may be indicative of the lack of total dissolution (since strontium is not expected to have the same volatility as cesium at the high vitrification temperatures). The $122 \%$ recovery for $\mathrm{V}-21$ also introduces the possibility of heterogeneity in the glass, unless an error was made in spiking (the higher strontium leachate concentration for V-21 is consistent with the latter). Assuming the total dissolution analysis results as representative of the glass composition, one can expect that at least about $50 \mathrm{wt} \%$ of the cesium will remain with the glass in operations similar to the laboratory crucible melting.

These glass samples proved quite leach resistant, as illustrated by the low leachate concentrations, even after leaching for a week. Table 25 lists the leachability indexes estimated for cesium and strontium from these single leachate analyses, assuming diffusion-controlled leaching with zero leachate concentration. Further analyses of the leachates indicated the silicon concentrations were $<0.02 \mathrm{mg} / \mathrm{L}$, well below the solubility limit for silica at room temperature in a neutral $\mathrm{pH}$, meaning that the leaching was not hampered by solubility limits of the glass matrix and diffusion control with zero leachate concentration over the leach interval of $6.85 \mathrm{~d}$ was a reasonable assumption. These results imply leachability indexes $>18$ for the sensitivity glasses, a challenge to measurement capability and well above the grout leachability indexes of 9-10.

\section{SUMMARY AND CONCLUSIONS}

An envelope, or operating window, for grout and glass formulations for a surrogate MVST sludge was identified and is documented in this report. Surrogate wet sludge loadings up to $55 \mathrm{wt} \%$ in grout met all performance criteria, resulting in volume increases of $40-50 \mathrm{vol} \%$ with little or no secondary waste generation. Higher loadings may result in free water, which violates the waste acceptance criteria of potential disposal facilities. Dewatering the sludge to $<52 \mathrm{wt} \%$ water allow higher waste loadings, with correspondingly lower volume increases, without sacrificing TCLP performance or leach resistance. The grout strength declines as the sludge loading increases, but a strong monolithic solid is not usually a waste acceptance criterion. 
Grouts stabilized the RCRA metals, including mercury (potentially a problem species for the tank sludges) and passed the TCLP test.

The tank sludges can be stabilized in glass at a waste oxide loading of $40-50 \mathrm{wt} \%$, resulting in a net volume decrease of 50-60 vol \%. This is a threefold decrease in final waste form volume compared with grout, not counting the secondary waste generation volume from off-gas treatment. The benefits of the lower glass volume compared with grout volume must be weighed against the generally higher capital and operating costs for vitrification, as well as the volume of secondary waste generated from both vitrification and grouting. RCRA metals incorporated into the glass matrix are stabilized and leach resistant, but mercury is volatilized and must be treated in the off-gas.

Confirmation of these results with actual hot sludge must be done prior to final acceptance of either technique. Hot testing of the grout and glass formulations with actual tank sludge samples was done subsequently to the work documented in this report. In addition, laboratory surrogate work continued at ORNL (grout) and the Savannah River Technology Center (glass) to apply this work to the sludges in other ORNL tank sets and to refine the formulations to allow higher waste loadings and lower volume increases.

\section{REFERENCES}

1. M. B. Sears, J. L. Botts, R. N. Ceo, J. J. Ferrada, W. H. Griest, J. M. Keller, and R. L. Schenley, Sampling and Analysis of Radioactive Liquid Wastes and Sludges in the Melton Valley and Evaporator Facility Storage Tanks at ORNL, ORNL/TM-11652, September 1990.

2. R. D. Spence, Personal Communication with V. L. Fowler, April 5, 1995.

3. J. R. Conner, Chemical Fixation and Solidification of Hazardous Wastes, Van Nostrand Reinhold, N.Y., 1990.

4. International Atomic Energy Agency, Improved Cement Solidification of Low and Intermedaiate Level Radioactive Wastes, Technical Reports Series No. 350, International Atomic Energy Agency, Vienna, 1993.

5. F. M. Lea, The Chemistry of Cement and Concrete, $3^{\text {rd }}$ edition, Chemical Publishing Co., Inc., N.Y., 1970.

6. I. Soroka, Portland Cement Paste and Concrete, Chemical Publishing Co., Inc., N.Y. 1979.

7. G. C. Bye, Portland Cement Composition, Production, and Properties, Pergamon Press, N.Y., 1983. 
8. S. N. Ghosh, editor, Advances in Cement Technology Critical Reviews and Case Studies on Manufacturing, Quality Control, Optimization and Use, Pergamon Press, N.Y., 1983.

9. H. F. W. Taylor, Cement Chemistry, Academic Press, N.Y., 1990.

10. U.S. EPA, Federal Register, 52(155), 29999 (Aug. 12, 1987).

11. P. Cote, Contaminant Leaching from Cement-Based Waste Forms Under Acidic Conditions, Ph.D. Thesis, McMaster Univ., Hamilton, Ont., Canada, 1986.

12. ASTM C 150-89, "Standard Specification for Portland Cement," pp. 92-99 in 1991 Annual Book of ASTM Standards Section 4 Construction, Vol. 04.02, Concrete and Aggregates, American Association for Testing and Materials, Philadelphia, Pa, 1991.

13. W. Laguna, "Radioactive Waste Disposal by Hydraulic Fracturing," Ind. Water Eng. 32-132 (October 1970).

14. T. G. Clendenning, A. E. Dalrymple, and T. W. Klym, "Current Technology in the Utilization and Disposal of Coal Ash," EngCon '75 (1975).

15. E. E. Berry and V. M. Malhotra, "Fly Ash for Use in Concrete - A Critical Review," J. Am. Concr. Inst., 77 (8), 59-73 (1980).

16. R. O. Lane and J. F. Best, "Properties and Use of Fly Ash in Portland Cement Concrete," Concr. Int. 4(7), 81-92 (1982).

17. R. E. Davis, R. W. Carlson, J. W. Kelley, and H. E. Davis, "Properties of Cement and Concrete Containing Fly Ash," $A C I J$, Proc. 33 (5) 577-612 (1937).

18. E. W. McDaniel, M. T. Morgan, J. G. Moore, H. E. Devaney, and L. R. Dole, Strontium Leachability of Hydrofracture Grouts for Sludge-Slurries, ORNL/TM-8198 (March 1982).

19. J. G. Moore, H. W. Godbee, A. H. Kibbey, and D. S. Joy, Development of Cementitious Grouts for the Incorporation of Radioactive Wastes. Part 1: Leach Studies, ORNL-4962 (August 1975).

20. J. G. Moore, Development of Cementitious Grouts for the Incorporation of Radioactive Wastes. Part 2: Continuation of Cesium and Strontium Leach Studies, ORNL-5142 (September 1976).

21. A. Atkinson, K. Nelson, and T. M. Valentine, "Leach Test Characterization of CementBased Nuclear Waste Forms," pp. 242-53 in Nuclear and Chemical Waste Management, Vol. 6, 1986. 
22. ASTM C 618-91, "Standard Specification for Fly Ash and Raw or Calcined Natural Pozzolan for Use as a Mineral Admixture in Portland Cement Concrete," pp. 303-305 in 1991 Annual Book of ASTM Standards Section 4 Construction, Vol. 04.02, Concrete and Aggregates, American Association for Testing and Materials, Philadelphia, Pa., 1991.

23. T. M. Gilliam and J. A. Loflin, Leachability Studies of Hydrofracture Grouts, ORNL/TM-9879, Oak Ridge National Laboratory, November 1986.

24. T. M. Gilliam, "Leach Testing of Hydrofracture Grouts Containing Hazardous Waste," Journal of the Underground Injection Practices Council, Vol. 1, pp. 192-212 (1986).

25. T. L. Sams, E. W. McDaniel, R. D. Spence, and T. M. Gilliam, Formulation Studies and Grout Development for Fixation of Neutralized Cladding Removal Waste, Milestone No. 181 - Part II, ORNL-6283.

26. T. Tamura, "Cesium Sorption Reactions as Indicator of Clay Mineral Structures," Clays Clay Minerals, Proc. Natl. Conf. Clays Clay Minerals 10, 389-98 (1961).

27. T. Tamura, "Cesium Sorption Reactions as Indicator of Clay Mineral Structures," Intern. Clay Conf., Proc. Conf. Stockholm, 1, 229-37 (1963).

28. T. Tamura and D. G. Jacobs, "Structural Implications in Cesium Sorption," Health Physics 2, 391-98 (1960).

29. R. W. Nurse, "Slag Cements," pp. 37-68 in The Chemistry of Cements, vol. 2, H. F. W. Taylor, ed., Academic Press, N.Y., 1984.

30. J. Daube and R. Bakker, "Portland Blast Furnace Slag Cement: A Review," pp. 5-14 in Blended Cements, G. Frohnnsdorff, ed., ASTM STP 897, ASTM, Philadelphia, Pa, 1986.

31. G. Frigione, "Manufacture and Characteristics of Portland Blast-Furnace Slag Cements," pp. 15-28 in Blended Cements, G. Frohnnsdorff, ed., ASTM STP 897, ASTM, Philadelphia, Pa.,1986.

32. V. S. Dubovoy, S. H. Gebler, P. Klieger, and D. A. Whiting, "Effects of Ground Granulated Blast-Furnace Slags on Some Properties of Pastes, Mortars, and Concretes," pp. 29-48, Blended Cements, G. Frohnnsdorff, ed., ASTM STP 897, ASTM, Philadelphia, Pa., 1986.

33. R. H. Mills, "Chemical Shrinkage and Differential Sorptions in Mixtures of Portland Cement and Blast-Furnace Slag," pp. 49-61 in Blended Cements, G. Frohnnsdorff, ed., ASTM STP 897, ASTM, Philadelphia, Pa., 1986. 
34. A. M. Neville, Properties of Concrete, $3^{\text {rd }}$ ed., Edward Arnold, Glasgow, 1970.

35. J. D. Palmer and D. L. G. Smith, The Incorporation of Low- and Medium-Level Radioactive Wastes (Solids and Liquids) in Cement, EUR-10561-EN, Commission of the European Communities, Luxembourg, 1986.

36. O. Brown, D. J. Lee, M. S. T. Price, and D. L. G. Smith, "Cement Based Processes for the Immobilization of Intermediate-Level Waste," Radioactive Waste Management, British Nuclear Society, London, 1985.

37. F. P. Glasser and C. McCulloch, Characterization of Radioactive Waste Forms, Progress Report for 1986, EUR-11354, Commission of the European Communities, Luxembourg, 1986.

38. M. J. Angus and F. P. Glasser, "The Chemical Environment in Cement Matrixes," Mater. Res. Soc. Symp. Proc., 50, 547-56(1986).

39. R. D. Spence, W. D. Bostick, E. W. McDaniel, T. M. Gilliam, J. L. Shoemaker, O. K. Tallent, I. L. Morgan, B. S. Evans-Brown, and K. E. Dodson, "Immobilization of Technetium in Blast Furnace Slag Grouts," presented at the $3^{\text {rd }}$ International Conference on the Use of Fly Ash, Silica Fume, Slag \& Natural Pozzolans in Concrete, Trondheim, Norway, June 19-24, 1989.

40. T. M. Gilliam et al., "Solidification/Stabilization of Technetium in Cement-Based Grouts," J. Hazardous Materials 24, 189-197 (1990).

41. R. D. Spence et al., "Cementitious Stabilization of Chromium, Arsenic, and Selenium in a Cooling Tower Sludge," presented at the 88th Annual Meeting of the Air \& Waste Management Association in San Antonio, Texas, June 18-23, 1995.

42. S. B. Clark and E. L. Wilhite, "Low-Level Liquid Waste Disposal at the Savannah River Site: A Large Scale Demonstration of Saltstone," WSRC-MS-90-210, DE92 009907, Westinghouse Savannah River Co., Savannah River Laboratory, Aiken, S.C., to be presented at Waste Management '91, Tucson, Ariz., Feb. 24-28, 1991.

43. C. A. Langton, M. D. Dukes, and R. V. Simmons, "Cement-Based Waste Forms for Disposal of Savannah River Plant Low-Level Radioactive Salt Waste," DP-MS-83-71, CONF-831174-61, DE84 005197, Savannah River Laboratory, Aiken, S.C.

44. C. A. Langton, "Solidification of Low-Level Radioactive Waste at the Savannah River Site," WSRC-RP-89-288, DE89 013770, Westinghouse Savannah River Company, Savannah River Laboratory, Aiken, S.C. 
45. C. A. Langton and P. B. Wong, "Properties of Slag Concrete for Low-Level Waste Containment," WSRC-MS-91-073, DE92 013194, Westinghouse Savannah River Company, Aiken, S.C., presented at the American Concrete Institute Spring Meeting, March 17-21, 1991.

46. D. W. Pepper, "Transport of Nitrate from a Large Cement-Based Wasteform," DPST-85963, DE88 004271, Savannah River Laboratory, Aiken, S.C.

47. H. C. Wolf, Large-Scale Demonstration of Disposal of Decontaminated Salt as Saltstone Part I: Construction, Loading, and Capping of Lysimeters, Savannah River Laboratory, Aiken, S.C., 1984.

48. S. B. Clark and E. L. Wilhite, "Low-Level Liquid Waste Disposal at the Savannah River Site: A Large Scale Demonstration of Saltstone," WSRC-MS-90-210, DE92 009907, Westinghouse Savannah River Co., Savannah River Laboratory, Aiken, S.C., presented at Waste Management '91, Tucson, Ariz., Feb. 24-28, 1991.

49. ASTM C 989-89, "Standard Specification for Ground Granulated Blast-Furnace Slag for Use in Concrete and Mortars," pp. 492-96 in 1991 Annual Book of ASTM Standards Section 4 Construction, Vol. 04.02, Concrete and Aggregates, American Association for Testing and Materials, Philadelphia, Pa., 1991.

50. ASTM C 204-91a, "Standard Specification for Fineness of Portland Cement by Air Permeability Apparatus," pp. 155-61 in 1991 Annual Book of ASTM Standards Section 4 Construction, Vol. 04.01, Cement; Lime; Gypsum, American Association for Testing and Materials, Philadelphia, Pa., 1991.

51. T. L. Sams, O. K. Tallent, and E. W. McDaniel, Preliminary Results of Grout Formulation Studies with Double Shell Slurry, Milestone 59, ORNL/TM-9824.

52. T. M. Gilliam, E. W. McDaniel, L. R. Dole, H. A. Friedman, J. A. Loflin, A. J. Mattus, I. L. Morgan, O. K. Tallent, and G. A. West, Summary Report on the Development of a Cement-Based Formula to Immobilize Hanford Facility Waste, ORNL/TM-10141 (September 1987).

53. E. W. McDaniel, T. M. Gilliam, and L. R. Dole, "Recommended Major Grout Components, ORNL Milestone \# 32, Project B-475, Transportable Grout Facility," letter report for the Hanford Grout Program, Apr. 15, 1984.

54. D. K. Smith, Cementing, Monograph Volume 4, SPE Henry L. Doherty Series, Society of Petroleum Engineers, Inc., N.Y. 1990.

55. D. K. Smith, "Physical Properties of Gel Cements," Pet. Eng. B7-B12 (April 1951). 
56. R. E. Grim, Applied Clay Mineralogy, McGraw-Hill, N.Y. 1962.

57. Technical Bulletin Data No. 201, American Callard Co., Chicago, I1l, 1945.

58. W. de Laguna et al., Engineering Development of Hydraulic Fracturing as a Method for Permanent Disposal of Radioactive Wastes, ORNL-4259 (August 1968).

59. API Specification for Oil-Well Drilling-Fluid Materials, API Spec 12A, $9^{\text {th }}$ edition, American Petroleum Institute, Dallas, Tex., March 1983.

60. "Specifications for Materials and Testing Oil-Well Cements," API Specification 10, $2^{\text {nd }}$ edition, API, Dallas, Tex., 1984.

61. EPA Handbook on Vitrification Technologies for Treatment of Hazardous and Radioactive Waste, U.S. Environmental Protection Agency, Office of Research and Development, Washington, D.C., EPA/625/R-92/002, May 1992.

62. A. K. Varshneya, Fundamentals of Inorganic Glasses, Academic Press, Inc., Harcourt Brace \& Company, San Diego, Calif., 1994.

63. M. B. Volf, Chemical Approach to Glass, Glass Science and Technology, vol. 7, Elvsevier, N.Y., 1984.

64. C. M. Jantzen, N. D. Hutson, T. M. Gilliam, A. Bleier, and R. D. Spence, Vitrification Treatability Studies of Actual Waste Water Treatment Sludges, U.S. DOE Report WSRCMS-95-0064, Savannah River Technology Center, Westinghouse Savannah River Co., Aiken, S.C., and Proceedings of Waste Management '95 (1995).

65. T. M. Gilliam et al., Vitrification of Waste Water Treatment Sludge Volume II: CrucibleScale Formulation Development Studies with Actual West End Treatment Facility Sludge Samples, Oak Ridge National Laboratory, Lockheed Martin Energy Research Corporation, Oak Ridge, Tenn., 1997.

66. T. M. Gilliam and C. M. Jantzen, "Waste Vitrification: Prediction of Acceptable Compositions in a Lime-Soda-Silica Glass-Forming System," in Scientific Basis for Nuclear Waste Management, XX, Materials Research Society, Pittsburgh, Pa., (1996).

67. J. A. Dean, ed., Lange's Handbook of Chemistry, 14th ed., McGraw-Hill, N.Y., 1992.

68. J. M. Stevels, Progress in the Theory of the Physical Properties of Glass, Elsever, Amsterdam, 1948.

69. J. M. Stevels, Phillips' Techn. Rdsch. 22, 337-49 (1960/61).

70. J. M. Stevels, Glass Ind. 35, 69 (1954). 
71. . E. M. Levin, C. R. Robbins, and H. F. McMurdie, Phase Diagrams for Ceramics, the American Ceramic Society.

72. C. M. Jantzen, "Relationship of Glass Composition to Glass Viscosity, Resistivity, Liquidus Temperature, and Durability: First Principles Process-Product Models for Vitrification of Nuclear Waste," pp. 37-51 in Ceramic Transactions, V. 23, American Ceramic Society, Westerville, Ohio, 1991.

73. C. M. Jantzen and K. G. Brown, "Statistical Process Control of Glass Manufactured for Nuclear Waste Disposal," Am. Ceram. Soc. Bull. 72(5), 55-59 (1993).

74. Final Report: Technical Resources Document on Solidification/Stabilization and Its Application to Waste Materials, Risk Reduction Engineering Laboratory, U.S. Environmental Protection Agency, Cincinnati, Ohio, February 1993.

75. W. Vogel, Chemistry of Glass, American Ceramic Society, Westerville, Ohio, 1985.

76. H. D. Schreiber, C. W. Schreiber, M.W. Riethmiller, and J. S. Downey, "The Effect of Temperature on the Redox Constraints for the Processing of High-Level Nuclear Waste into a Glass Waste Form," pp. 419-25 in Scientific Basis for Nuclear Waste Management, XIII, V. M. Oversby and P. W. Brown, eds., Materials Research Society, Pittsburgh, Pa., 1990.

77. M. J. Plodinec, "Factors Affecting the Iron Oxidation State and Foaming in SRP Waste Glass," pp. 201-11 in Proceedings of the Symposium on High Temperature Materials Chemistry, D. D. Cubicciotti and D. L. Hildebrand, eds., The Electrochemical Society, Pennington, N.J., 1982.

78. M. J. Plodinec, Foaming During Vitrification of SRP Waste, U.S. DOE Report DPST-86213, E.I. duPont deNemours \& Co., Savannah River Laboratory, Aiken, S.C., January 1986.

79. H. D. Schreiber and A. L. Hockman, "Redox Chemistry in Candidate Glasses for Nuclear Waste Immobilization," J. Am. Ceram. Soc., 70(8), 591-94 (1987).

80. H. D. Schreiber, P. G. Leonhard, R. G. Nofsinger, M. W. Henning, C. W. Schreiber, and S. J. Kozak, "Oxidation-Reduction Chemistry of NonMetals in a Reference Borosilicate Melt," Advances in the Fusion of Glass 29(14) 1-19 (1988). D. F. Bickford, W. E. Horsfall, F. E. Wooley, E. N. Boulos, J. N. Linscheit, F. Harding, F. Olix, W. C. LaCourse, and L. D. Pye, eds., Am. Ceram. Soc., Westerville, Ohio, 1988. 


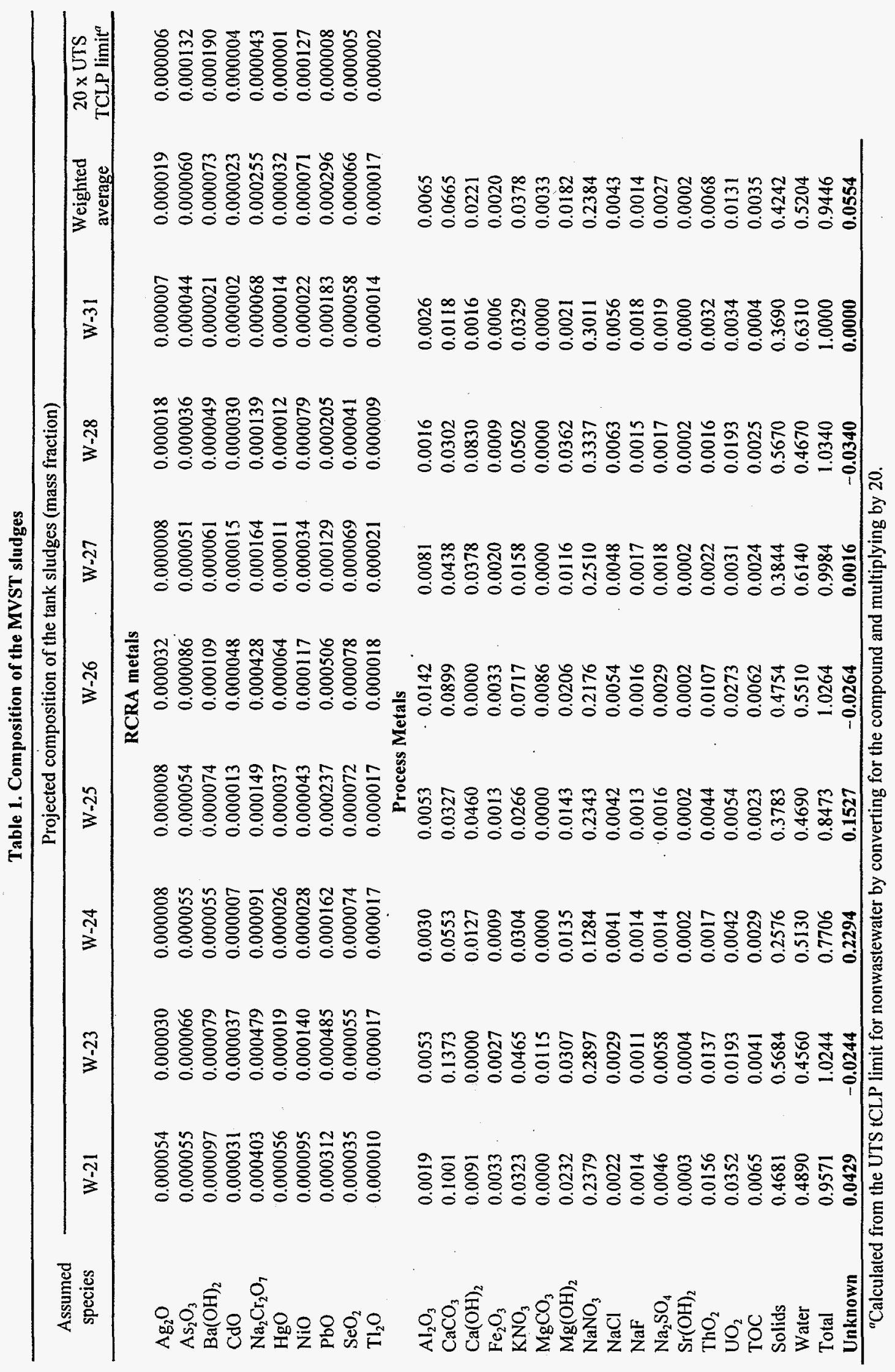


Table 2. Target composition for the surrogate MVST sludge

\begin{tabular}{|c|c|}
\hline Compound & Mass fraction \\
\hline \multicolumn{2}{|c|}{ RCRA metals } \\
\hline $\mathrm{Ag}_{2} \mathrm{O}$ & 0.000019 \\
\hline $\mathrm{CdO}$ & 0.000023 \\
\hline $\mathrm{Na}_{2} \mathrm{Cr}_{2} \mathrm{O}_{7}$ & 0.000255 \\
\hline $\mathrm{HgCl}_{2}$ & 0.000040 \\
\hline $\mathrm{PbO}$ & 0.000296 \\
\hline $\mathrm{SeO}_{2}$ & 0.000066 \\
\hline $\mathrm{TINO}_{3}$ & 0.000021 \\
\hline \multicolumn{2}{|c|}{ Process metals } \\
\hline $\mathrm{Al}(\mathrm{OH})_{3}$ & 0.0099 \\
\hline $\mathrm{CaCO}_{3}$ & 0.0665 \\
\hline $\mathrm{Ca}(\mathrm{OH})_{2}$ & 0.0221 \\
\hline $\mathrm{Fe}_{2} \mathrm{O}_{3}$ & 0.0020 \\
\hline $\mathrm{KNO}_{3}$ & 0.0378 \\
\hline $\mathrm{MgCO}_{3}$ & 0.0033 \\
\hline $\mathrm{Mg}(\mathrm{OH})_{2}$ & 0.0182 \\
\hline $\mathrm{NaNO}_{3}$ & 0.2790 \\
\hline $\mathrm{NaCl}$ & 0.0043 \\
\hline $\mathrm{NaF}$ & 0.0014 \\
\hline $\mathrm{Na}_{2} \mathrm{SO}_{4}$ & 0.0027 \\
\hline $\mathrm{Sr}\left(\mathrm{NO}_{3}\right)_{2}$ & 0.0004 \\
\hline $\mathrm{Th}\left(\mathrm{NO}_{3}\right)_{4} \cdot 4 \mathrm{H}_{2} \mathrm{O}$ & 0.0141 \\
\hline $\mathrm{UO}_{2}\left(\mathrm{NO}_{3}\right)_{2} \cdot 6 \mathrm{H}_{2} \mathrm{O}$ & 0.0244 \\
\hline Total solids & 0.4866 \\
\hline Water & 0.5134 \\
\hline Sludge & 1.0000 \\
\hline
\end{tabular}




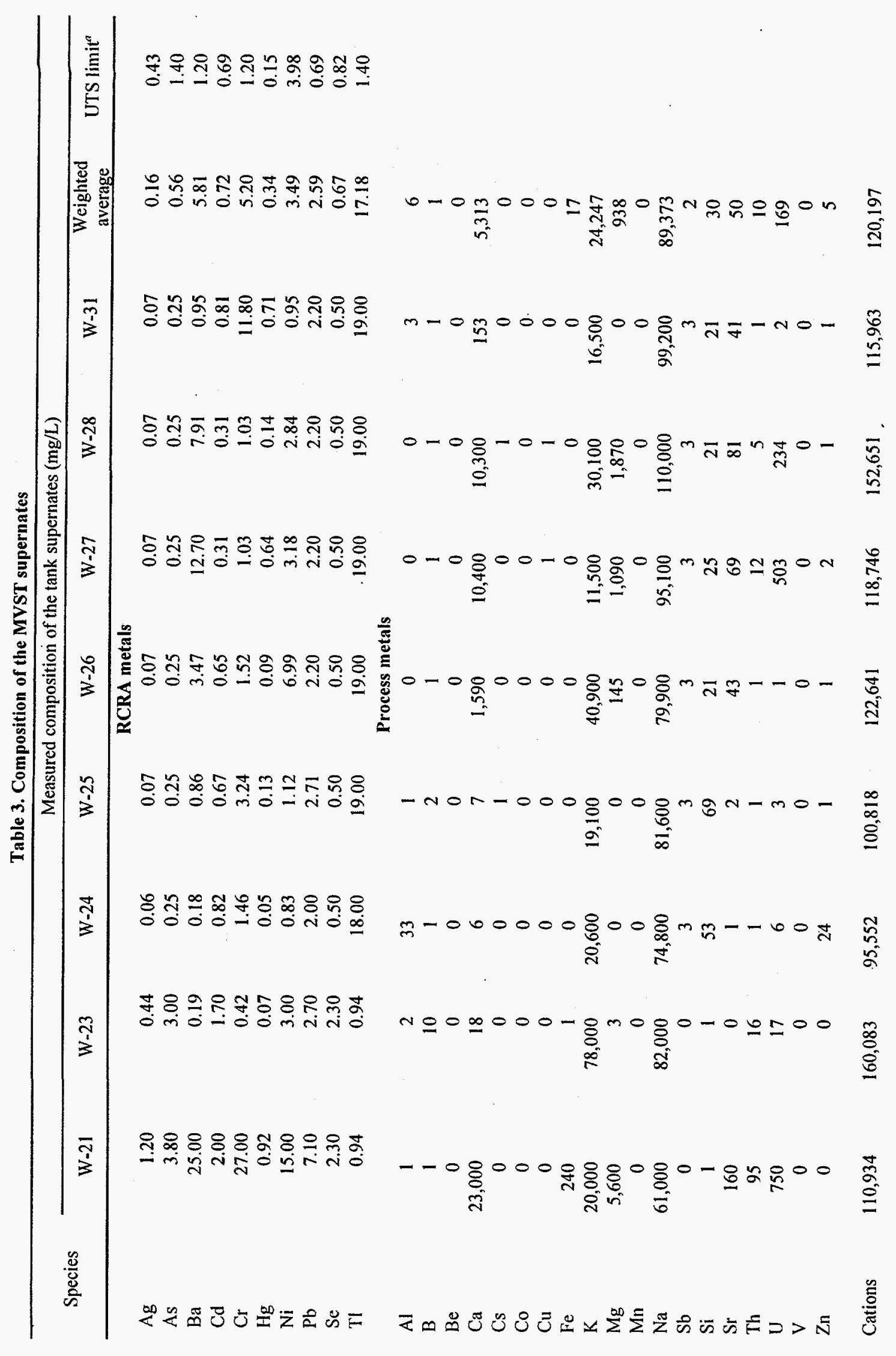




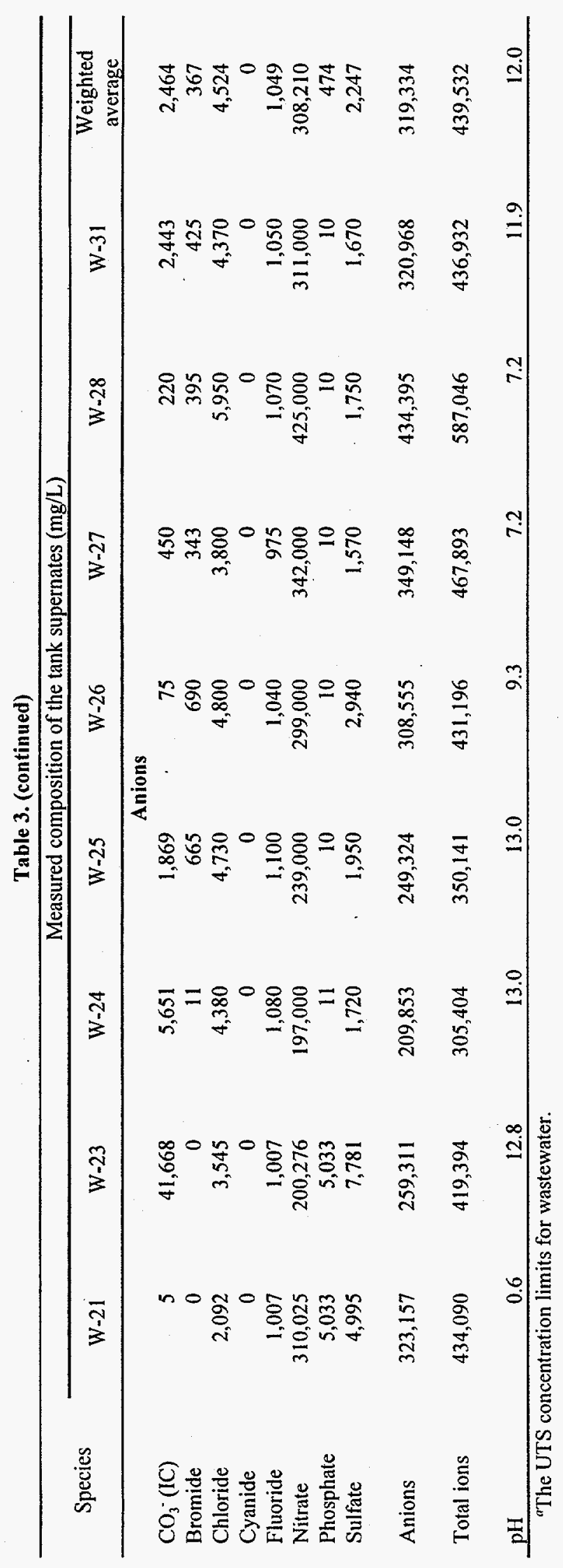


Table 4. Target composition for the surrogate MVST supernate

\begin{tabular}{|c|c|}
\hline Compound & $\mathrm{mg} / \mathrm{L}$ \\
\hline \multicolumn{2}{|c|}{ RCRA metals } \\
\hline $\mathrm{Ba}(\mathrm{OH})_{2}$ & 7.25 \\
\hline $\mathrm{CdO}$ & 0.82 \\
\hline $\mathrm{Na}_{2} \mathrm{Cr}_{2} \mathrm{O}_{7}$ & 13.10 \\
\hline $\mathrm{HgCl}_{2}$ & 0.46 \\
\hline $\mathrm{PbO}$ & 2.79 \\
\hline $\mathrm{TINO}_{3}$ & 22.39 \\
\hline \multicolumn{2}{|c|}{ Process metals } \\
\hline $\mathrm{Ca}(\mathrm{OH})_{2}$ & 6,780 \\
\hline $\mathrm{KNO}_{3}$ & 62,695 \\
\hline $\mathrm{Mg}(\mathrm{OH})_{2}$ & 2,249 \\
\hline $\mathrm{NaNO}_{3}$ & 369,782 \\
\hline $\mathrm{CaCO}_{3}$ & 4,109 \\
\hline $\mathrm{NaBr}$ & 473 \\
\hline $\mathrm{NaCl}$ & 7,458 \\
\hline $\mathrm{NaF}$ & 2,318 \\
\hline $\mathrm{Na}_{2} \mathrm{SO}_{4}$ & 3,322 \\
\hline $\mathrm{pH}$ & 12.0 \\
\hline
\end{tabular}


Table 5. Ionic concentrations for the surrogate MVST supernate in Table 4

\begin{tabular}{|c|c|}
\hline & $\mathrm{mg} / \mathrm{L}$ \\
\hline \multicolumn{2}{|c|}{ RCRA metals } \\
\hline $\mathrm{Ba}$ & 5.81 \\
\hline $\mathrm{Cd}$ & 0.72 \\
\hline $\mathrm{Cr}$ & 5.20 \\
\hline $\mathrm{Hg}$ & 0.34 \\
\hline $\mathrm{Pb}$ & 2.59 \\
\hline $\mathrm{Tl}$ & 17.18 \\
\hline \multicolumn{2}{|c|}{ Process metals } \\
\hline $\mathrm{Ca}$ & 5,313 \\
\hline K & 24,247 \\
\hline $\mathrm{Mg}$ & 938 \\
\hline $\mathrm{Na}$ & 106,126 \\
\hline \multicolumn{2}{|c|}{ Anions } \\
\hline Carbonate & 2,464 \\
\hline Bromide & 367 \\
\hline Chloride & 4,524 \\
\hline Fluoride & 1,049 \\
\hline Nitrate & 308,215 \\
\hline Sulfate & 2,247 \\
\hline
\end{tabular}


Table 6. Composition of the grouts tested during the scoping tests

\begin{tabular}{|c|c|c|c|c|c|c|c|c|}
\hline \multirow[b]{2}{*}{ Grout no. } & \multirow[b]{2}{*}{$\begin{array}{c}\text { Surrogate } \\
\text { wet sludge } \\
\text { (wt\%) }\end{array}$} & \multirow[b]{2}{*}{$\begin{array}{c}\text { Surrogate } \\
\text { supernate } \\
(w t \%)\end{array}$} & \multicolumn{5}{|c|}{ Dry blend } & \multirow[b]{2}{*}{ W/S } \\
\hline & & & $\begin{array}{c}\text { Slag } \\
(w t \%)\end{array}$ & $\begin{array}{c}\text { Cement } \\
(w t \%)\end{array}$ & $\begin{array}{l}\text { Fly Ash } \\
(w t \%)\end{array}$ & $\begin{array}{l}\text { IRPC } \\
(w t \%)\end{array}$ & $\begin{array}{l}\text { Water } \\
\text { sorptive } \\
\text { agent } \\
\text { (wt\%) }\end{array}$ & \\
\hline 1 & 33.1 & 10.6 & 46.7 & 5.1 & 0.0 & 4.5 & 0.0 & 0.39 \\
\hline 2 & 27.8 & 16.7 & 22.8 & 2.8 & 25.6 & 4.4 & 0.0 & 0.45 \\
\hline 3 & 66.7 & 0.0 & 27.7 & 3.0 & 0.0 & 2.7 & 0.0 & 0.53 \\
\hline 4 & 67.0 & 0.0 & 13.5 & 1.7 & 15.2 & 2.6 & 0.0 & 0.53 \\
\hline 5 & 54.9 & 0.0 & 37.4 & 4.1 & 0.0 & 3.6 & 0.0 & 0.40 \\
\hline 6 & 38.5 & 30.0 & 26.2 & 2.8 & 0.0 & 2.5 & 0.0 & 1.00 \\
\hline 7 & 30.8 & 44.0 & 20.9 & 2.3 & 0.0 & 2.0 & 0.0 & 1.50 \\
\hline 8 & 25.6 & 53.3 & 17.5 & 1.9 & 0.0 & 1.7 & 0.0 & 2.00 \\
\hline 9 & 54.9 & 0.0 & 18.5 & 2.3 & 20.7 & 3.6 & 0.0 & 0.40 \\
\hline 10 & 38.5 & 30.0 & 12.9 & 1.6 & 14.5 & 2.5 & 0.0 & 1.00 \\
\hline 11 & 30.8 & 44.0 & 10.4 & 1.3 & 11.6 & 2.0 & 0.0 & 1.50 \\
\hline 12 & 25.7 & 53.3 & 8.6 & 1.1 & 9.7 & 1.7 & 0.0 & 2.00 \\
\hline 13 & 67.0 & 0.0 & 12.5 & 1.3 & 14.9 & 2.6 & $1.7^{a}$ & 0.53 \\
\hline 14 & 67.0 & 0.0 & 12.5 & 1.3 & 13.2 & 2.6 & $3.3^{a}$ & 0.53 \\
\hline 15 & 67.0 & 0.0 & 10.9 & 1.3 & 13.2 & 2.6 & $5.0^{\circ}$ & 0.53 \\
\hline 16 & 67.0 & 0.0 & 10.9 & 1.3 & 11.6 & 2.6 & $6.6^{\circ}$ & 0.53 \\
\hline 17 & 67.0 & 0.0 & 12.5 & 1.3 & 14.9 & 2.6 & $1.7^{b}$ & 0.53 \\
\hline 18 & 67.0 & 0.0 & 13.2 & 1.3 & 13.2 & 2.6 & $2.6^{b}$ & 0.53 \\
\hline 19 & 67.0 & 0.0 & 12.5 & 1.3 & 12.5 & 2.6 & $4.0^{6}$ & 0.53 \\
\hline 20 & 67.0 & 0.0 & 12.2 & 1.3 & 11.9 & 2.6 & $5.0^{b}$ & 0.53 \\
\hline 21 & 67.0 & 0.0 & 10.9 & 1.3 & 11.6 & 2.6 & $6.6^{a}$ & 0.53 \\
\hline 22 & 67.0 & 0.0 & 10.9 & 3.3 & 9.6 & 2.6 & $6.6^{a}$ & 0.53 \\
\hline 23 & 67.0 & 0.0 & 10.9 & 5.0 & 7.9 & 2.6 & $6.6^{a}$ & 0.53 \\
\hline 24 & 67.0 & 0.0 & 10.9 & 6.6 & 6.3 & 2.6 & $6.6^{a}$ & 0.53 \\
\hline 25 & 67.0 & 0.0 & 12.5 & 1.3 & 14.9 & 2.6 & $1.7^{c}$ & 0.53 \\
\hline 26 & 67.0 & 0.0 & 13.2 & 1.3 & 13.2 & 2.6 & $2.6^{c}$ & 0.53 \\
\hline 27 & 67.0 & 0.0 & 12.5 & 1.3 & 12.5 & 2.6 & $4.0^{c}$ & 0.53 \\
\hline 28 & 67.0 & 0.0 & 12.2 & 1.3 & 11.9 & 2.6 & $5.0^{c}$ & 0.53 \\
\hline 29 & 67.0 & 0.0 & 7.9 & 7.9 & 7.9 & 2.6 & $6.6^{\circ}$ & 0.53 \\
\hline 30 & 67.0 & 0.0 & 6.9 & 9.9 & 6.9 & 2.6 & $6.6^{\circ}$ & 0.53 \\
\hline 31 & 67.0 & 0.0 & 5.9 & 11.9 & 5.9 & 2.6 & $6.6^{a}$ & 0.53 \\
\hline 32 & 67.0 & 0.0 & 5.0 & 13.9 & 5.0 & 2.6 & $6.6^{a}$ & 0.53 \\
\hline 33 & 27.4 & 20.5 & 17.2 & 10.4 & 9.9 & 4.2 & $10.4^{a}$ & 0.53 \\
\hline 34 & 32.9 & 24.3 & 14.1 & 8.6 & 8.1 & 3.4 & $8.6^{a}$ & 0.71 \\
\hline 35 & 42.9 & 16.7 & 13.3 & 8.1 & 7.7 & 3.2 & $8.1^{\circ}$ & 0.64 \\
\hline 36 & 56.3 & 6.1 & 12.4 & 7.5 & 7.1 & 3.0 & $7.5^{a}$ & 0.55 \\
\hline 37 & 70.0 & 0.0 & 9.9 & 6.0 & 5.7 & 2.4 & $6.0^{\circ}$ & 0.57 \\
\hline 38 & 80.0 & 0.0 & 6.6 & 4.0 & 3.8 & 1.6 & $4.0^{a}$ & 0.71 \\
\hline 39 & 90.0 & 0.0 & 3.3 & 2.0 & 1.9 & 0.8 & $2.0^{a}$ & 0.88 \\
\hline
\end{tabular}

aperlite

${ }^{b}$ Attapulgite

Bentonite 
Table 7. The measured grout densities and grout volume relative to the surrogate MVST wet sludge volume for the scoping tests

\begin{tabular}{ccc}
\hline Grout no. & $\begin{array}{c}\text { Grout density } \\
(\mathrm{g} / \mathrm{mL})\end{array}$ & $\begin{array}{c}\text { Volume ratio of } \\
\text { grout to wet } \\
\text { sludge }^{a}\end{array}$ \\
\hline 1 & 1.90 & 2.22 \\
2 & 1.84 & 2.74 \\
3 & 1.62 & 1.29 \\
4 & 1.63 & 1.28 \\
5 & 1.73 & 1.47 \\
6 & 1.63 & 2.23 \\
7 & 1.58 & 2.88 \\
8 & 1.54 & 3.54 \\
9 & 1.73 & 1.47 \\
10 & 1.58 & 2.30 \\
11 & 1.52 & 2.99 \\
12 & 1.45 & 3.76 \\
13 & 1.61 & 1.30 \\
14 & 1.63 & 1.28 \\
15 & 1.60 & 1.30 \\
16 & 1.60 & 1.30 \\
17 & 1.63 & 1.28 \\
18 & 1.63 & 1.28 \\
19 & 1.63 & 1.28 \\
20 & 1.62 & 1.29 \\
21 & 1.61 & 1.30 \\
22 & 1.60 & 1.30 \\
23 & 1.62 & 1.29 \\
24 & 1.62 & 1.29 \\
25 & 1.63 & 1.28 \\
26 & 1.64 & 1.27 \\
27 & 1.64 & 1.27 \\
28 & 1.65 & 1.26 \\
29 & 1.68 & 1.24 \\
30 & 1.69 & 1.23 \\
31 & 1.66 & 1.26 \\
32 & 1.68 & 1.24 \\
33 & 1.72 & 2.96 \\
34 & 1.70 & 2.50 \\
35 & 1.69 & 1.92 \\
36 & 1.71 & 1.45 \\
37 & 1.62 & 1.23 \\
38 & 1.53 & 1.05 \\
39 & 1.49 & \\
\hline
\end{tabular}

${ }^{a}$ Calculated from the wet sludge loading, grout density, and the measured surrogate MVST wet sludge density of $1.40 \mathrm{~g} / \mathrm{mL}$. 
Table 8. Free water and penetration resistance measured for the scoping test grouts

\begin{tabular}{|c|c|c|c|c|c|c|c|c|}
\hline \multirow{2}{*}{ Grout no. } & \multicolumn{4}{|c|}{ Free water (vol\%) } & \multicolumn{4}{|c|}{ Penetration resistance (psi) } \\
\hline & $1 \mathrm{~d}$ & $3 d$ & $5 \mathrm{~d}$ & $7 \mathrm{~d}$ & $1 \mathrm{~d}$ & $3 \mathrm{~d}$ & $5 d$ & $7 \mathrm{~d}$ \\
\hline 1 & 0.4 & 0.0 & & 0.0 & 0 & 0 & & 3,840 \\
\hline 2 & 0.8 & 0.8 & & 0.0 & 0 & 80 & & $>8,000$ \\
\hline 3 & 8.0 & 8.0 & & 7.2 & 0 & 1,280 & & 5,960 \\
\hline 4 & 6.0 & 8.0 & & 7.2 & 0 & 160 & & 2,520 \\
\hline 5 & 0.8 & 0.0 & & 0.0 & 0 & 3,000 & & $>8,000$ \\
\hline 6 & 8.0 & 7.2 & & 6.4 & 0 & 0 & & 3,600 \\
\hline 7 & 18.4 & 17.6 & & 16.4 & 0 & 0 & & 960 \\
\hline 8 & 26.4 & 25.2 & & 24.8 & 0 & 0 & & 240 \\
\hline 9 & 1.6 & 0.8 & & 0.8 & 160 & & & 3,440 \\
\hline 10 & 16.8 & 17.6 & & 16.0 & 0 & & & 2,360 \\
\hline 11 & 28.8 & 28.4 & & 27.2 & 0 & & & 1,240 \\
\hline 12 & 39.2 & 39.2 & & 39.2 & 0 & 80 & & 880 \\
\hline 13 & 8.8 & 8.8 & & 8.0 & 0 & 360 & & 1,720 \\
\hline 14 & 5.6 & 4.8 & & 4.0 & 0 & 480 & & 1,440 \\
\hline 15 & 4.8 & 4.0 & & 4.0 & 0 & 280 & & 1,960 \\
\hline 16 & 4.0 & 4.0 & & 3.2 & 0 & 440 & & 960 \\
\hline 17 & 16.0 & 15.2 & & 14.4 & 0 & 640 & & 2,000 \\
\hline 18 & 13.6 & 12.8 & & 12.4 & 0 & 720 & & 2,320 \\
\hline 19 & 12.8 & 12.0 & & 11.6 & 0 & 680 & & 2,120 \\
\hline 20 & 10.4 & 9.6 & & 9.6 & 0 & 280 & & 1,600 \\
\hline 21 & 6.8 & 6.0 & 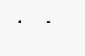 & 5.6 & 0 & 800 & & 2,000 \\
\hline 22 & 4.0 & 3.6 & & 2.8 & 0 & 920 & & 4,560 \\
\hline 23 & 2.4 & 2.0 & & 1.6 & 0 & 1,200 & & 6,160 \\
\hline 24 & 2.4 & 1.6 & & 1.2 & 0 & 920 & & 5,560 \\
\hline 25 & 11.2 & & 12.0 & 12.0 & 0 & & 760 & 1,600 \\
\hline 26 & 9.2 & & 8.8 & 9.2 & 0 & & 640 & 1,240 \\
\hline 27 & 8.0 & & 7.2 & 7.6 & 0 & & 480 & 892 \\
\hline 28 & 5.2 & & 4.4 & 4.4 & 0 & & 400 & 760 \\
\hline 29 & 4.0 & 3.2 & & 2.4 & & 240 & & 3,720 \\
\hline 30 & 3.6 & 2.0 & & 1.6 & & 480 & & 4,800 \\
\hline 31 & 3.6 & 2.4 & & 2.0 & & 480 & & 4,240 \\
\hline 32 & 4.4 & 3.6 & & 2.8 & & 680 & & 3,920 \\
\hline 33 & 0.8 & 0.4 & & 0.2 & & $>8,000$ & & $>8,000$ \\
\hline 34 & 0.8 & 0.8 & & 0.4 & & $>8,000$ & & $>8,000$ \\
\hline 35 & 0.8 & 0.0 & & 0.0 & & $>8,000$ & & $>8,000$ \\
\hline 36 & 1.2 & 0.8 & & 0.8 & & $>8,000$ & & $>8,000$ \\
\hline 37 & 1.6 & 1.6 & & 0.8 & & 3,760 & & 4,600 \\
\hline 38 & 5.6 & 4.0 & & 4.0 & & 960 & & 1,680 \\
\hline 39 & 19.2 & 18.4 & & 18.4 & & 0 & & 0 \\
\hline
\end{tabular}


Table 9. Concentrations of the RCRA metals and uranium in the TCLP extract of the surrogate MVST sludge

\begin{tabular}{ccccc}
\hline & \multicolumn{3}{c}{ TCLP extract concentration (mg/L) } \\
\cline { 2 - 5 } Analyte & Sludge sample & UTS limits $^{a}$ & $\begin{array}{c}\text { RCRA } \\
\text { characteristic }^{\text {limits }}{ }^{b}\end{array}$ & $\begin{array}{c}\text { TCLP LDR } \\
\text { limits }^{c}\end{array}$ \\
\hline $\mathrm{Cd}$ & 0.904 & 0.190 & 1.000 & 1.000 \\
$\mathrm{Cr}$ & 2.69 & 0.86 & 5.00 & 5.00 \\
$\mathrm{Hg}$ & 1.54 & 0.025 & 0.200 & 0.200 \\
$\mathrm{~Pb}$ & 0.111 & 0.370 & 5.000 & 5.000 \\
$\mathrm{Se}$ & 0.118 & 0.160 & 1.000 & 5.700 \\
$\mathrm{Tl}$ & 0.486 & 0.078 & N/A & N/A \\
$\mathrm{U}$ & 511 & $\mathrm{~N} / \mathrm{A}$ & $\mathrm{N} / \mathrm{A}$ & $\mathrm{N} / \mathrm{A}$ \\
& & & & \\
TCLP Fluid No. & 2 & & & \\
& & & & \\
$\mathrm{pH}$ & 6.75 & & & \\
\hline
\end{tabular}

${ }^{a}$ The Universal Treatment Standard limits for the TCLP extract concentration.

${ }^{b}$ Toxicity limits for TCLP extract concentrations in determining whether a waste is characteristically hazardous by the RCRA.

The TCLP extract concentration limits by the LDR of the RCRA.

"Not applicable. 
Table 10. Concentrations of the RCRA metals and uranium in the TCLP extract of the grouts from the scoping tests

\begin{tabular}{|c|c|c|c|c|c|c|c|c|c|}
\hline \multirow{2}{*}{ Grout no. } & \multicolumn{7}{|c|}{ TCLP extract concentration (mg/L) } & \multirow{2}{*}{$\begin{array}{c}\text { TCLP } \\
\text { fluid no. }\end{array}$} & \multirow{2}{*}{$\mathrm{pH}$} \\
\hline & $\mathrm{Cd}$ & $\mathrm{Cr}$ & $\mathrm{Hg}$ & $\mathrm{Pb}$ & $\mathrm{Se}$ & $\mathrm{Tl}$ & $\mathrm{U}$ & & \\
\hline 1 & $<0.002$ & $<0.002$ & $<0.011$ & $<0.004$ & 0.173 & $<0.006$ & 0.174 & 2 & 9.40 \\
\hline 2 & $<0.002$ & $<0.002$ & $<0.011$ & $<0.004$ & 0.486 & 0.008 & 0.206 & 2 & 9.34 \\
\hline 3 & $<0.003$ & $<0.003$ & $<0.022$ & $<0.009$ & 0.305 & $<0.011$ & 0.170 & 2 & 9.06 \\
\hline 4 & $<0.003$ & $<0.003$ & $<0.022$ & $<0.009$ & 0.334 & 0.014 & 107 & 2 & 8.37 \\
\hline 5 & $<0.003$ & $<0.003$ & $<0.022$ & $<0.009$ & 0.245 & $<0.011$ & 0.237 & 2 & 9.84 \\
\hline 6 & $<0.003$ & $<0.003$ & $<0.022$ & $<0.009$ & 0.281 & $<0.011$ & 0.376 & 2 & 9.54 \\
\hline 7 & $<0.003$ & $<0.003$ & $<0.022$ & $<0.009$ & 0.373 & $<0.011$ & 0.479 & 2 & 9.50 \\
\hline 8 & $<0.003$ & $<0.003$ & $<0.022$ & $<0.009$ & 0.350 & $<0.011$ & 0.376 & 2 & 8.95 \\
\hline 9 & $<0.003$ & $<0.003$ & $<0.022$ & $<0.009$ & 0.287 & $<0.011$ & 53.1 & 2 & 8.58 \\
\hline 10 & $<0.003$ & $<0.003$ & $<0.022$ & $<0.009$ & 0.252 & $<0.011$ & 96.7 & 2 & 8.31 \\
\hline 11 & $<0.003$ & $<0.003$ & $<0.022$ & $<0.009$ & 0.220 & $<0.011$ & 83.2 & 2 & 8.40 \\
\hline 12 & $<0.003$ & $<0.003$ & & $<0.009$ & 0.198 & 0.042 & 117 & 2 & 7.48 \\
\hline 13 & $<0.003$ & $<0: 003$ & & $<0.009$ & 0.088 & 0.020 & 111 & 2 & 8.26 \\
\hline 14 & $<0.003$ & $<0.003$ & & $<0.009$ & 0.082 & 0.018 & 122 & 2 & 8.29 \\
\hline 15 & $<0.003$ & $<0.003$ & & $<0.009$ & 0.102 & 0.027 & 160 & 2 & 8.31 \\
\hline 16 & $<0.003$ & $<0.003$ & & $<0.009$ & 0.109 & 0.033 & 225 & 2 & 8.21 \\
\hline 17 & $<0.003$ & $<0.003$ & & $<0.009$ & 0.255 & $<0.011$ & 138 & 2 & 8.31 \\
\hline 18 & $<0.003$ & $<0.003$ & & $<0.009$ & 0.234 & 0.017 & 73.5 & 2 & 8.50 \\
\hline 19 & $<0.003$ & $<0.003$ & & $<0.009$ & 0.206 & $<0.011$ & 107 & 2 & 8.39 \\
\hline 20 & $<0.003$ & $<0.003$ & & $<0.009$ & 0.207 & 0.020 & 98.7 & 2 & 8.39 \\
\hline 21 & $<0.003$ & $<0.003$ & & $<0.009$ & 0.279 & 0.020 & 141 & 2 & 8.13 \\
\hline 22 & $<0.003$ & $<0.003$ & & $<0.009$ & 0.178 & $<0.011$ & 105 & 2 & 8.14 \\
\hline 23 & $<0.003$ & $<0.003$ & & $<0.009$ & 0.164 & $<0.011$ & 79.4 & 2 & 8.34 \\
\hline 24 & $<0.003$ & $<0.003$ & & $<0.009$ & 0.157 & $<0.011$ & 39.7 & 2 & 8.39 \\
\hline 25 & $<0.003$ & $<0.003$ & & $<0.009$ & 0.065 & 0.014 & 67.3 & 2 & 8.43 \\
\hline 26 & $<0.003$ & 0.022 & & $<0.009$ & 0.063 & 0.020 & 59.3 & 2 & 8.40 \\
\hline 27 & $<0.003$ & $<0.003$ & & $<0.009$ & 0.073 & 0.019 & 60.6 & 2 & 8.46 \\
\hline 28 & $<0.003$ & $<0.003$ & & $<0.009$ & 0.073 & 0.032 & 38.3 & 2 & 8.34 \\
\hline 29 & $<0.003$ & 0.003 & & $<0.009$ & 0.025 & 0.041 & 1.21 & 2 & 6.45 \\
\hline 30 & $<0.003$ & 0.004 & & $<0.009$ & 0.022 & 0.039 & 4.17 & 2 & 5.53 \\
\hline 31 & $<0.003$ & 0.003 & & $<0.009$ & $<0.018$ & 0.039 & 0.75 & 2 & 5.80 \\
\hline 32 & $<0.003$ & 0.008 & & $<0.009$ & $<0.018$ & 0.042 & 4.43 & 2 & 5.48 \\
\hline 33 & $<0.003$ & 0.007 & & 0.011 & 0.040 & $<0.011$ & $<0.078$ & 1 & 10.75 \\
\hline 34 & $<0.003$ & 0.006 & & 0.013 & 0.040 & $<0.011$ & $<0.078$ & 1 & 10.60 \\
\hline 35 & $<0.003$ & 0.010 & & 0.013 & 0.053 & $<0.011$ & $<0.078$ & 1 & 10.55 \\
\hline 36 & $<0.003$ & 0.015 & & 0.013 & 0.073 & $<0.011$ & $<0.078$ & 1 & 10.74 \\
\hline 37 & $<0.003$ & $<0.003$ & . & $<0.009$ & 0.103 & $<0.011$ & 13.7 & 2 & 8.63 \\
\hline 38 & $<0.003$ & $<0.003$ & & $<0.009$ & 0.078 & 0.015 & 83.9 & 2 & 8.48 \\
\hline 39 & $<0.003$ & $<0.003$ & & $<0.009$ & 0.090 & 0.053 & 379 & 2 & 8.32 \\
\hline $\begin{array}{l}\text { TCLP } \\
\text { UTS }^{b}\end{array}$ & 0.190 & 0.860 & 0.025 & 0.370 & 0.160 & 0.078 & $N / A^{a}$ & & \\
\hline
\end{tabular}

Not applicable.

${ }^{5}$ The UTS limits for the TCLP extract concentration. 
Table 11. Grout compositions for sensitivity testing of grouting the surrogate MVST sludge

\begin{tabular}{lccccc}
\hline $\begin{array}{c}\text { Grout } \\
\text { component }\end{array}$ & Grout \#1 (Std) & Grout \#2 & Grout \#3 & Grout \#4 & Grout \#5 \\
\hline IRPC & 0.036 & High waste loading (mass fraction) & & \\
Perlite & 0.090 & 0.032 & 0.040 & 0.038 & 0.034 \\
Fly ash & 0.086 & 0.080 & 0.100 & 0.094 & 0.085 \\
Slag & 0.149 & 0.076 & 0.095 & 0.089 & 0.081 \\
Cement & 0.090 & 0.132 & 0.165 & 0.127 & 0.172 \\
Wet sludge & 0.550 & 0.080 & 0.100 & 0.077 & 0.104 \\
Supernate & 0.000 & 0.599 & 0.500 & 0.575 & 0.522 \\
Total & 1.000 & 0.000 & 0.000 & 0.000 & 0.000 \\
W/S & 1.000 & 1.000 & 1.000 & 1.000 \\
& $0.40^{b}$ & 0.45 & 0.35 & 0.43 & 0.37 \\
IRPC & & Low waste loading (mass fraction) & & \\
Perlite & 0.042 & 0.041 & 0.046 & 0.044 & 0.040 \\
Fly ash & 0.000 & 0.000 & 0.000 & 0.000 & 0.000 \\
Slag & 0.240 & 0.238 & 0.263 & 0.251 & 0.228 \\
Cement & 0.214 & 0.212 & 0.234 & 0.183 & 0.248 \\
Wet sludge & 0.026 & 0.026 & 0.029 & 0.022 & 0.030 \\
Supernate & 0.400 & 0.484 & 0.358 & 0.418 & 0.380 \\
Total & 0.078 & 0.000 & 0.070 & 0.082 & 0.074 \\
W/S & 1.000 & 1.000 & 1.000 & 1.000 & 1.000 \\
\hline
\end{tabular}

${ }^{a}$ For the standard surrogate MVST sludge.

${ }^{b} \mathrm{~W} / \mathrm{S}=0.53$ for the surrogate MVST sludge with the maximum water; $\mathrm{W} / \mathrm{S}=0.33$ for the surrogate MVST sludge with the minimum water and maximum bad actors.

${ }^{c} \mathrm{~W} / \mathrm{S}=0.49$ for the surrogate MVST sludge with the maximum water; W/S $=0.35$ for the surrogate MVST sludge with the minimum water and maximum bad actors. 
Table 12. Surrogate MVST sludge compositions used in sensitivity testing

\begin{tabular}{|c|c|c|c|}
\hline Compound & Standard surrogate & Maximum water & $\begin{array}{l}\text { Minimum water }+ \\
\text { maximum bad actors }\end{array}$ \\
\hline \multicolumn{4}{|c|}{ RCRA metals (mass fraction) } \\
\hline $\mathrm{Ag}_{2} \mathrm{O}$ & 0.000019 & 0.000014 & 0.000054 \\
\hline $\mathrm{CdO}$ & 0.000023 & 0.000018 & 0.000048 \\
\hline $\mathrm{Na}_{2} \mathrm{Cr}_{2} \mathrm{O}_{7}$ & 0.000255 & 0.000193 & 0.000479 \\
\hline $\mathrm{HgCl}_{2}$ & 0.000040 & 0.000030 & 0.000080 \\
\hline $\mathrm{PbO}$ & 0.000296 & 0.000224 & 0.000506 \\
\hline $\mathrm{SeO}_{2}$ & 0.000066 & 0.000050 & 0.000078 \\
\hline $\mathrm{TlNO}_{3}$ & 0.000021 & 0.000016 & 0.000026 \\
\hline \multicolumn{4}{|c|}{ Process metals (mass fraction) } \\
\hline $\mathrm{Al}(\mathrm{OH})_{3}$ & 0.0099 & 0.0075 & 0.0110 \\
\hline $\mathrm{CaCO}_{3}$ & 0.0665 & 0.0504 & 0.1373 \\
\hline $\mathrm{Ca}(\mathrm{OH})_{2}$ & 0.0221 & 0.0168 & 0.0247 \\
\hline $\mathrm{Fe}_{2} \mathrm{O}_{3}$ & 0.0020 & 0.0015 & 0.0022 \\
\hline $\mathrm{KNO}_{3}$ & 0.0378 & 0.0287 & 0.0423 \\
\hline $\mathrm{MgCO}_{3}$ & 0.0033 & 0.0025 & 0.0037 \\
\hline $\mathrm{Mg}(\mathrm{OH})_{2}$ & 0.0182 & 0.0138 & 0.0203 \\
\hline $\mathrm{NaNO}_{3}$ & 0.2787 & 0.2113 & 0.1887 \\
\hline $\mathrm{NaCl}$ & 0.0043 & 0.0033 & 0.0063 \\
\hline $\mathrm{NaF}$ & 0.0014 & 0.0011 & 0.0018 \\
\hline $\mathrm{Na}_{2} \mathrm{SO}_{4}$ & 0.0027 & 0.0021 & 0.0058 \\
\hline $\mathrm{Sr}\left(\mathrm{NO}_{3}\right)_{2}$ & 0.0004 & 0.0003 & 0.0004 \\
\hline $\mathrm{Th}\left(\mathrm{NO}_{3}\right)_{4} \cdot 4 \mathrm{H}_{2} \mathrm{O}$ & 0.0141 & 0.0107 & 0.0326 \\
\hline $\mathrm{UO}_{2}\left(\mathrm{NO}_{3}\right)_{2} \cdot 6 \mathrm{H}_{2} \mathrm{O}$ & 0.0244 & 0.0185 & 0.0655 \\
\hline Total solids & 0.4866 & 0.3690 & 0.5440 \\
\hline Water & 0.5134 & 0.6310 & 0.4560 \\
\hline Sludge & 1.0000 & 1.0000 & 1.0000 \\
\hline
\end{tabular}


Table 13. The measured grout densities and grout volume relative to the surrogate MVST wet sludge volume for the sensitivity testing grouts

\begin{tabular}{cccc}
\hline Surrogate MVST sludge & Grout no. & $\begin{array}{c}\text { Grout density } \\
(\mathrm{g} / \mathrm{mL})\end{array}$ & $\begin{array}{c}\text { Volume ratio of } \\
\text { grout to wet } \\
\text { sludge }\end{array}$ \\
\hline Standard & High waste loading & \\
& 1 & 1.76 & 1.44 \\
& 2 & 1.72 & 1.36 \\
Minimum water + & 3 & 1.78 & 1.57 \\
maximum bad actors & 4 & 1.75 & 1.39 \\
Maximum water & 1 & 1.82 & 1.47 \\
Standard & 1 & 1.64 & 1.55 \\
& Low waste loading & 1.82 & 1.39 \\
& 1 & 1.81 & 1.93 \\
& 2 & 1.84 & 1.57 \\
Minimum water + & 3 & 1.85 & 2.11 \\
Maximum bad actors & 4 & 1.80 & 1.86 \\
\hline & 5 & 1.84 & 2.00 \\
& 1 & 1.74 & 2.01 \\
& 1 & 1.91 & 1.83 \\
\hline
\end{tabular}


Table 14. Free waters measured for the sensitivity testing grouts

\begin{tabular}{|c|c|c|c|c|c|c|}
\hline \multirow{2}{*}{$\begin{array}{c}\text { Surrogate } \\
\text { MVST } \\
\text { sludge }\end{array}$} & \multirow{2}{*}{ Grout no. } & \multicolumn{5}{|c|}{ Free water (vol\%) } \\
\hline & & $1 \mathrm{~d}$ & $3 \mathrm{~d}$ & $5 d$ & $7 d$ & $28 \mathrm{~d}$ \\
\hline \multicolumn{7}{|c|}{ High waste loading } \\
\hline \multirow[t]{5}{*}{ Standard } & 1 & 0.4 & & 0.0 & & 0.0 \\
\hline & 2 & 1.6 & 0.8 & & ' & 0.0 \\
\hline & 3 & 0.0 & 0.0 & & & 0.0 \\
\hline & 4 & 0.4 & 0.0 & & & 0.0 \\
\hline & 5 & 0.0 & 0.0 & & & 0.0 \\
\hline $\begin{array}{c}\text { Minimum } \\
\text { water }+ \\
\text { maximum } \\
\text { bad actors }\end{array}$ & 1 & 0.0 & & 0.0 & & 0.0 \\
\hline $\begin{array}{l}\text { Maximum } \\
\text { water }\end{array}$ & 1 & 0.0 & & & & 0.0 \\
\hline \multicolumn{7}{|c|}{ Low waste loading } \\
\hline \multirow[t]{5}{*}{ Standard } & 1 & 0.0 & & & & 0.0 \\
\hline & 2 & 0.4 & 0.0 & & & 0.0 \\
\hline & 3 & 0.0 & 0.0 & & & 0.0 \\
\hline & 4 & 1.2 & 1.6 & & 0.8 & 0.0 \\
\hline & 5 & 0.8 & 0.0 & & & 0.0 \\
\hline $\begin{array}{c}\text { Minimum } \\
\text { water }+ \\
\text { maximum } \\
\text { bad actors }\end{array}$ & 1 & 3.2 & & 1.2 & & 0.0 \\
\hline $\begin{array}{l}\text { Maximum } \\
\text { water }\end{array}$ & 1 & 0.8 & & 0.0 & & 0.0 \\
\hline
\end{tabular}


Table 15. Unconfined compressive strengths measured for the sensitivity testing grouts

\begin{tabular}{|c|c|c|c|c|c|c|}
\hline \multirow{2}{*}{$\begin{array}{l}\text { Surrogate } \\
\text { MVST } \\
\text { sludge }\end{array}$} & \multirow{2}{*}{ Grout no. } & \multicolumn{5}{|c|}{ Unconfined compressive strength (psi) } \\
\hline & & 1 & 2 & 3 & Avg. & Std. dev. \\
\hline \multicolumn{7}{|c|}{ High waste loading } \\
\hline \multirow[t]{5}{*}{ Standard } & 1 & 1959 & 1367 & & 1663 & 296 \\
\hline & 2 & 373 & 992 & 964 & 776 & 286 \\
\hline & 3 & 1688 & 1865 & 1485 & 1679 & 155 \\
\hline & 4 & 720 & 2842 & & 1781 & 1061 \\
\hline & 5 & 2121 & 2191 & 1945 & 2086 & 103 \\
\hline $\begin{array}{l}\text { Minimum } \\
\text { water }+ \\
\text { maximum } \\
\text { bad actors }\end{array}$ & 1 & 1042 & 1560 & 1414 & 1339 & 218 \\
\hline $\begin{array}{l}\text { Maximum } \\
\text { water }\end{array}$ & 1 & 899 & 2107 & 2425 & 1810 & 657 \\
\hline \multicolumn{7}{|c|}{ Low waste loading } \\
\hline \multirow[t]{5}{*}{ Standard } & 1 & 472 & 593 & 561 & 542 & 51 \\
\hline & 2 & 158 & 40 & 340 & 179 & 123 \\
\hline & 3 & 928 & 960 & 989 & 959 & 25 \\
\hline & 4 & 464 & 543 & & 504 & 39 \\
\hline & 5 & 716 & 637 & & 676 & 39 \\
\hline $\begin{array}{l}\text { Minimum } \\
\text { water }+ \\
\text { maximum } \\
\text { bad actors }\end{array}$ & 1 & 572 & 443 & & 507 & 65 \\
\hline $\begin{array}{l}\text { Maximum } \\
\text { water }\end{array}$ & 1 & 1276 & 2500 & & 1888 & 612 \\
\hline
\end{tabular}


Table 16. TCLP extract concentrations measured for the sensitivity testing grouts

\begin{tabular}{|c|c|c|c|c|c|c|c|c|c|c|}
\hline \multirow{2}{*}{$\begin{array}{l}\text { Surr. } \\
\text { MVST } \\
\text { sludge }\end{array}$} & \multirow{2}{*}{$\begin{array}{c}\text { Grout } \\
\text { no. }\end{array}$} & \multicolumn{7}{|c|}{ TCLP extract concentration, $\mathrm{mg} / \mathrm{L}$} & \multirow{2}{*}{$\begin{array}{l}\text { TCLP } \\
\text { fluid no. }\end{array}$} & \multirow{2}{*}{$\mathrm{pH}$} \\
\hline & & $\mathrm{Cd}$ & $\mathrm{Cr}$ & $\mathrm{Hg}^{a}$ & $\mathrm{~Pb}$ & $\mathrm{Se}$ & $\mathrm{Tl}$ & $\mathrm{U}$ & & \\
\hline \multicolumn{11}{|c|}{ High waste loading } \\
\hline \multirow[t]{5}{*}{ Std. } & 1 & $<0.002$ & 0.014 & 0.0002 & 0.009 & 0.053 & $<0.006$ & 0.071 & 1 & 10.23 \\
\hline & 2 & $<0.002$ & 0.013 & 0.0003 & 0.016 & 0.028 & $<0.006$ & $<0.039$ & 1 & 10.50 \\
\hline & 3 & $<0.002$ & 0.011 & 0.0004 & 0.009 & 0.041 & $<0.006$ & $<0.039$ & 1 & 10.29 \\
\hline & 4 & $<0.002$ & 0.014 & 0.0004 & 0.008 & 0.130 & $<0.006$ & $<0.039$ & 1 & 10.36 \\
\hline & 5 & $<0.002$ & 0.010 & 0.0003 & 0.008 & 0.083 & $<0.006$ & $<0.039$ & 1 & 10.41 \\
\hline $\begin{array}{c}\text { Min. } \\
\text { water + } \\
\text { max. bad } \\
\text { actors }\end{array}$ & 1 & $<0.002$ & 0.022 & 0.0001 & 0.009 & 0.034 & $<0.006$ & $<0.039$ & 1 & 10.43 \\
\hline $\begin{array}{l}\text { Max. } \\
\text { water }\end{array}$ & 1 & $<0.002$ & 0.038 & 0.0002 & 0.012 & 0.019 & $<0.006$ & 0.103 & 1 & 10.51 \\
\hline \multicolumn{11}{|c|}{ Low waste loading } \\
\hline \multirow[t]{5}{*}{ Std. } & 1 & $<0.003$ & $<0.003$ & $<0.0001$ & $<0.009$ & 0.234 & $<0.011$ & 6.491 & 2 & 9.52 \\
\hline & 2 & $<0.002$ & 0.005 & 0.0003 & 0.009 & 0.058 & $<0.006$ & $<0.039$ & 1 & 10.47 \\
\hline & 3 & $<0.002$ & 0.005 & 0.0003 & 0.009 & 0.059 & $<0.006$ & $<0.039$ & 1 & 10.62 \\
\hline & 4 & $<0.002$ & 0.007 & 0.0002 & 0.010 & 0.187 & $<0.006$ & $<0.039$ & 1 & 10.56 \\
\hline & 5 & $<0.002$ & 0.007 & 0.0004 & 0.009 & 0.078 & $<0.006$ & $<0.039$ & 1 & 10.66 \\
\hline $\begin{array}{c}\text { Min. } \\
\text { water }+ \\
\text { max. bad } \\
\text { actors }\end{array}$ & 1 & $<0.002$ & 0.005 & 0.0001 & 0.009 & 0.068 & $<0.006$ & $<0.039$ & 1 & 10.51 \\
\hline $\begin{array}{l}\text { Max. } \\
\text { water }\end{array}$ & 1 & $<0.002$ & 0.066 & 0.0002 & 0.015 & 0.107 & $<0.006$ & 0.3 & 1 & 10.52 \\
\hline \multicolumn{11}{|c|}{ TCLP UTS $^{b}$} \\
\hline & & 0.190 & 0.860 & 0.025 & 0.370 & 0.160 & 0.078 & $N / A^{c}$ & & \\
\hline
\end{tabular}

${ }^{a}$ Measured by cold vapor atomic absorption; all other extract concentrations were measured by ICP.

bThe UTS limits for the TCLP extract concentration.

Not applicable. 
Table 17. The measured leachability indexes of ${ }^{85} \mathrm{Sr}$ and ${ }^{137} \mathrm{Cs}$ for the sensitivity testing grouts

\begin{tabular}{cccc}
\hline \multirow{2}{*}{ Surrogate MVST sludge } & Grout no. & \multicolumn{2}{c}{ Leachability index } \\
\cline { 3 - 4 } Standard & High waste loading & ${ }^{85} \mathrm{Cs}$ \\
\hline & 1 & $9.5^{a}$ & $9.9^{\circ}$ \\
& 2 & 9.4 & 9.7 \\
& 3 & 10.0 & 10.5 \\
Minimum water + maximum & 4 & 9.4 & 9.9 \\
bad actors & 5 & 9.9 & 10.1 \\
Maximum water & 1 & 9.2 & 9.3 \\
& & & 10.5 \\
Standard & 1 & 9.6 & \\
& Low waste loading & & $9.5^{a}$ \\
& 1 & $8.7^{a}$ & 9.4 \\
Minimum water + maximum & 2 & 8.7 & 10.1 \\
bad actors & 3 & 9.1 & 8.7 \\
Maximum water & 4 & 8.0 & 10.2 \\
& 1 & 9.5 & 8.7 \\
\hline
\end{tabular}

${ }^{a}$ Average of three. 
Table 18. Calculated surrogate composition on an oxide basis

\begin{tabular}{|c|c|}
\hline Species & $\mathrm{g} / \mathrm{kg} \mathrm{dry}$-waste \\
\hline $\mathrm{Ag} / \mathrm{Ag}_{2} \mathrm{O}$ & 0.040 \\
\hline $\mathrm{Al} / \mathrm{Al}_{2} \mathrm{O}_{3}$ & 13.467 \\
\hline $\mathrm{As} / \mathrm{As}_{2} \mathrm{O}_{3}$ & 0.000 \\
\hline $\mathrm{Au} / \mathrm{Au}_{2} \mathrm{O}$ & 0.000 \\
\hline $\mathrm{B} / \mathrm{B}_{2} \mathrm{O}_{3}$ & 0.000 \\
\hline $\mathrm{Ba} / \mathrm{BaO}$ & 0.000 \\
\hline $\mathrm{Ca} / \mathrm{CaO}$ & 112.500 \\
\hline $\mathrm{Cd} / \mathrm{CdO}$ & 0.048 \\
\hline $\mathrm{Ce} / \mathrm{Ce}_{2} \mathrm{O}_{3}$ & 0.000 \\
\hline $\mathrm{Ce} / \mathrm{CeO}_{2}$ & 0.000 \\
\hline $\mathrm{Co} / \mathrm{CoO}$ & 0.000 \\
\hline $\mathrm{Co} / \mathrm{Co}_{3} \mathrm{O}_{4}$ & 0.000 \\
\hline $\mathrm{Cr} / \mathrm{Cr}_{2} \mathrm{O}_{3}$ & 0.309 \\
\hline $\mathrm{Cs} / \mathrm{Cs}_{2} \mathrm{O}$ & 0.000 \\
\hline $\mathrm{Cu} / \mathrm{CuO}$ & 0.000 \\
\hline $\mathrm{Fe} / \mathrm{Fe}_{2} \mathrm{O}_{3}$ & 4.170 \\
\hline $\mathrm{Fe} / \mathrm{FeO}$ & 0.000 \\
\hline $\mathrm{K} / \mathrm{K}_{2} \mathrm{O}$ & 36.712 \\
\hline $\mathrm{La} / \mathrm{La}_{2} \mathrm{O}_{3}$ & 0.000 \\
\hline $\mathrm{Li} / \mathrm{Li}_{2} \mathrm{O}$ & 0.000 \\
\hline $\mathrm{Mg} / \mathrm{MgO}$ & 29.505 \\
\hline $\mathrm{Mn} / \mathrm{MnO}$ & 0.000 \\
\hline $\mathrm{Mn} / \mathrm{MnO}_{2}$ & 0.000 \\
\hline $\mathrm{Mo} / \mathrm{MoO}_{3}$ & 0.000 \\
\hline $\mathrm{Na} / \mathrm{Na}_{2} \mathrm{O}$ & 221.655 \\
\hline $\mathrm{Nd} / \mathrm{Nd}_{2} \mathrm{O}_{3}$ & 0.000 \\
\hline $\mathrm{Ni} / \mathrm{NiO}$ & 0.000 \\
\hline $\mathrm{P} / \mathrm{P}_{2} \mathrm{O}_{s}$ & 0.000 \\
\hline $\mathrm{Pb} / \mathrm{PbO}$ & 0.617 \\
\hline $\mathrm{Rb} / \mathrm{Rb}_{2} \mathrm{O}$ & 0.000 \\
\hline $\mathrm{Ru} / \mathrm{RuO}_{2}$ & 0.000 \\
\hline $\mathrm{Sb} / \mathrm{Sb}_{2} \mathrm{O}_{3}$ & 0.007 \\
\hline $\mathrm{Se} / \mathrm{SeO}_{2}^{-}$ & 0.138 \\
\hline $\mathrm{Si} / \mathrm{SiO}_{2}$ & 0.000 \\
\hline $\mathrm{Sn} / \mathrm{SnO} 2$ & 0.000 \\
\hline $\mathrm{Sr} / \mathrm{SrO}$ & 0.341 \\
\hline $\mathrm{Tc} / \mathrm{TcO}_{2}$ & 0.000 \\
\hline $\mathrm{Te} / \mathrm{TeO}_{2}$ & 0.000 \\
\hline $\mathrm{Th} / \mathrm{ThO}_{2}$ & 15.987 \\
\hline $\mathrm{Ti} / \mathrm{TiO}_{2}$ & 0.000 \\
\hline $\mathrm{U} / \mathrm{UO}_{3}$ & 29.036 \\
\hline $\mathrm{U} / \mathrm{UO}_{2}$ & 0.000 \\
\hline $\mathrm{T} / / \mathrm{Tl}_{2} \mathrm{O}$ & 0.035 \\
\hline $\mathrm{Zn} / \mathrm{ZnO}$ & 0.000 \\
\hline $\mathrm{Zr} / \mathrm{ZrO}_{2}$ & 0.000 \\
\hline $\mathrm{S} / \mathrm{SO}_{4}$ & 3.781 \\
\hline $\mathrm{Cl} / \mathrm{Cl}_{2} \mathrm{O}$ & 6.793 \\
\hline $\mathbf{F}$ & 1.300 \\
\hline Totals & 475.141 \\
\hline
\end{tabular}




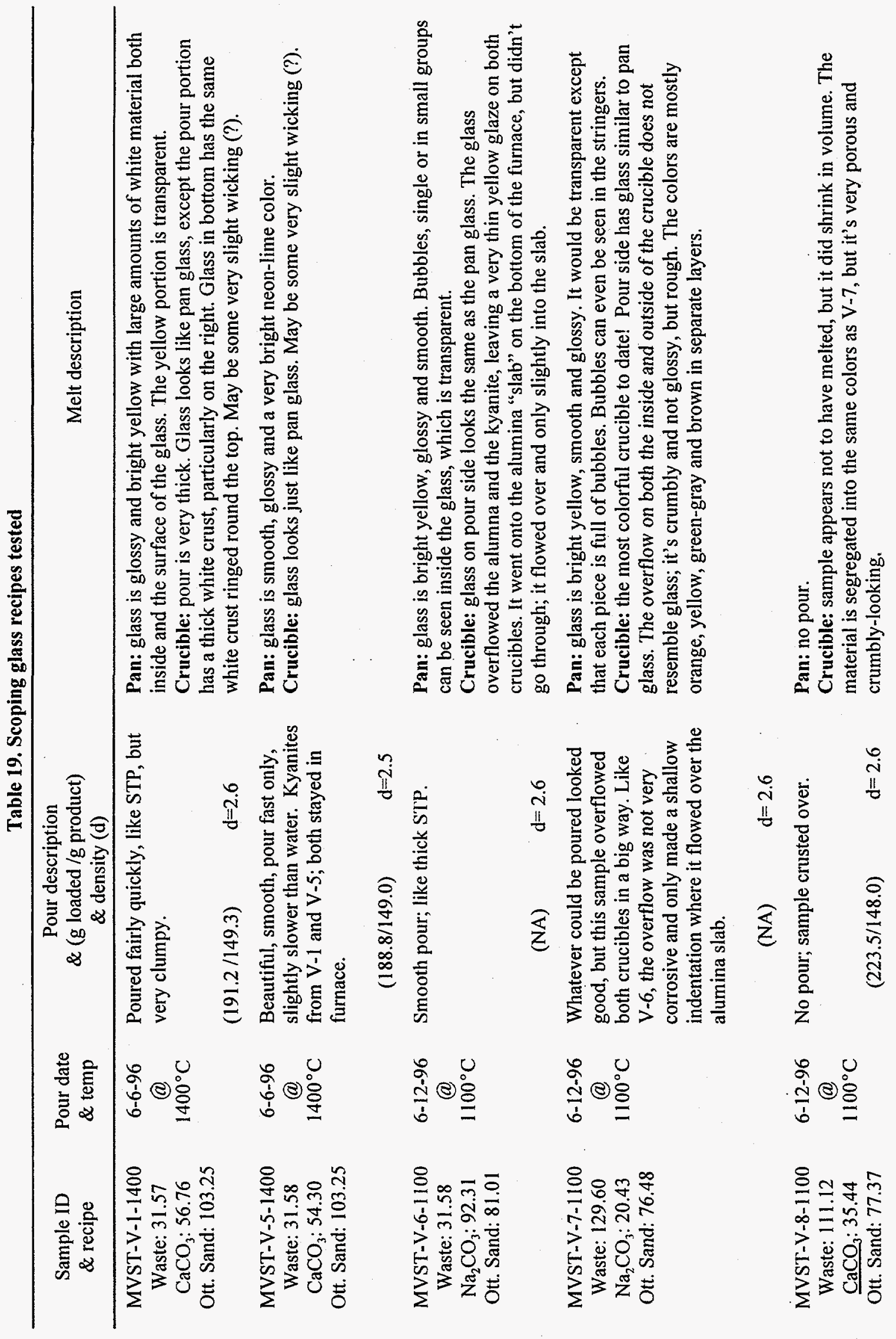




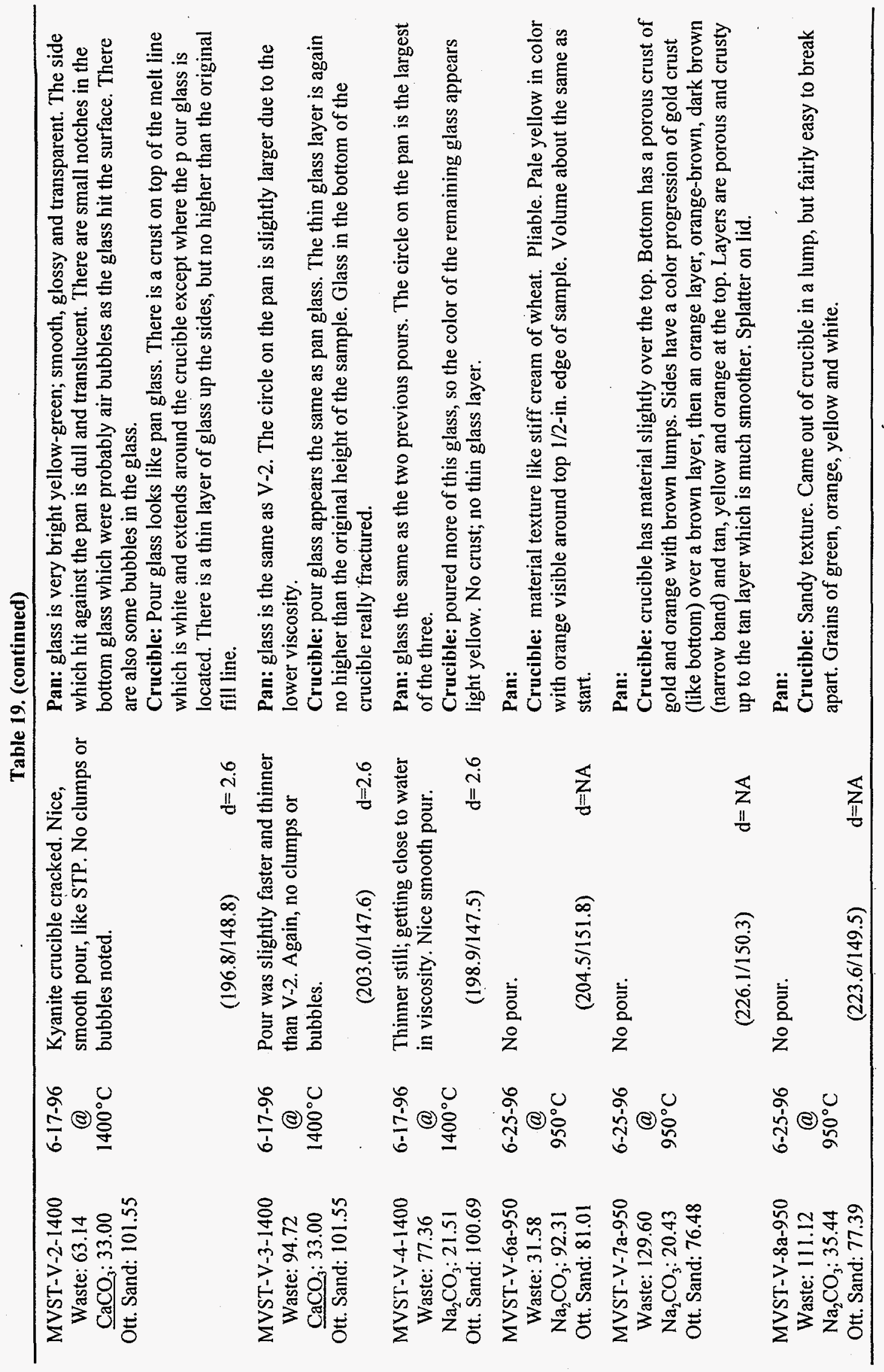


Table 20. TCLP values (mg/L) from scoping glasses prepared with MVST surrogate

\begin{tabular}{|c|c|c|c|c|c|c|c|c|c|c|c|c|}
\hline Species & $V-1$ & $V-2$ & $V-3$ & $V-4$ & $V-5$ & V-6 & $V-7$ & V-9 & $V-10$ & $V-11$ & $V-12$ & V-13 \\
\hline $\mathrm{Ag}$ & 0.002 & 0.004 & 0.004 & 0.004 & 0.002 & 0.004 & 0.004 & 0.002 & 0.002 & 0.002 & 0.002 & 0.002 \\
\hline Al & 0.033 & 0.067 & 0.263 & 0.358 & 0.033 & 0.778 & 1.876 & 1.107 & 0.929 & 1.212 & 1.376 & 0.363 \\
\hline As & 0.008 & 0.016 & 0.016 & 0.016 & 0.008 & 0.016 & 0.016 & 0.008 & 0.008 & 0.008 & 0.008 & 0.008 \\
\hline B & 0.219 & 0.294 & 0.316 & 0.316 & 0.199 & 0.313 & 0.864 & 1.054 & 0.961 & 1.191 & 1.534 & 0.983 \\
\hline $\mathrm{Ba}$ & 0.303 & 0.411 & 0.470 & 0.522 & 0.280 & 0.327 & 0.992 & 1.496 & 1.561 & 1.569 & 1.677 & 1.151 \\
\hline $\mathrm{Be}$ & 0.001 & 0.002 & 0.002 & 0.002 & 0.001 & 0.002 & 0.002 & 0.001 & 0.001 & 0.001 & 0.001 & 0.006 \\
\hline $\mathrm{Ca}$ & 2.265 & 1.850 & 1.700 & 1.880 & 0.681 & 0.600 & 136.4 & 390.0 & 395.0 & 396.0 & 390.0 & 1.220 \\
\hline $\mathrm{Cd}$ & 0.002 & 0.003 & 0.003 & 0.003 & 0.002 & 0.003 & 0.034 & 0.012 & 0.013 & 0.012 & 0.015 & 0.007 \\
\hline $\mathrm{Cr}$ & 0.003 & 0.007 & 0.012 & 0.060 & 0.056 & 0.033 & 0.041 & 0.104 & 0.100 & 0.102 & 0.112 & 0.009 \\
\hline $\mathrm{Fe}$ & 0.066 & 0.079 & 0.320 & 0.139 & 0.064 & 0.136 & 0.158 & 0.336 & 0.311 & 0.354 & 0.399 & 0.153 \\
\hline $\mathrm{K}$ & 0.635 & 0.152 & 0.263 & 0.552 & 4.280 & 31.60 & 10.85 & 21.67 & 23.21 & 22.13 & 21.83 & 0.711 \\
\hline $\mathrm{Mg}$ & 0.049 & 0.040 & 0.040 & 0.092 & 0.075 & 0.271 & 8.710 & 14.02 & 14.90 & 14.32 & 14.89 & 0.181 \\
\hline $\mathrm{Mn}$ & 0.001 & 0.018 & 0.023 & 0.385 & 0.004 & 0.007 & 0.008 & 0.007 & 0.005 & 0.010 & 0.004 & 0.009 \\
\hline $\mathrm{Na}$ & 1087 & 1394 & 1417 & 1470 & 1411 & 2181 & 1645 & 1767 & 1790 & 1817 & 1735 & 1527 \\
\hline $\mathrm{Ni}$ & 0.004 & 0.009 & 0.009 & 0.013 & 0.004 & 0.009 & 0.009 & 0.004 & 0.007 & 0.004 & 0.004 & 0.085 \\
\hline $\mathrm{Pb}$ & 0.004 & 0.012 & 0.016 & 0.016 & 0.004 & 0.022 & 0.143 & 0.049 & 0.049 & 0.053 & 0.056 & 0.018 \\
\hline $\mathrm{Se}$ & 0.009 & 0.018 & 0.018 & 0.018 & 0.009 & 0.018 & 0.046 & 0.009 & 0.009 & 0.009 & 0.009 & 0.012 \\
\hline $\mathrm{Sb}$ & 0.006 & 0.011 & 0.011 & 0.011 & 0.006 & 0.011 & 0.011 & 0.006 & 0.006 & 0.006 & 0.006 & 0.008 \\
\hline $\mathrm{Si}$ & 1.300 & 1.490 & 1.750 & 2.420 & 2.900 & 74.42 & 96.26 & 68.30 & 70.40 & 75.30 & 71.20 & 1.554 \\
\hline $\mathrm{Ti}$ & 0.001 & 0.002 & 0.002 & 0.002 & 0.001 & 0.004 & 0.002 & 0.011 & 0.010 & 0.011 & 0.013 & 0.009 \\
\hline $\mathrm{Tl}$ & 0.006 & 0.011 & 0.011 & 0.011 & 0.006 & 0.011 & 0.011 & 0.006 & 0.006 & 0.006 & 0.006 & 0.006 \\
\hline $\mathrm{U}$ & 0.039 & 0.078 & 0.078 & 0.135 & 0.054 & 0.427 & 8.470 & 3.010 & 2.790 & 3.120 & 3.500 & 0.039 \\
\hline V & 0.009 & 0.018 & 0.018 & 0.018 & 0.009 & 0.018 & 0.021 & 0.041 & 0.043 & 0.048 & 0.042 & 0.028 \\
\hline $\mathrm{Zn}$ & 0.383 & 0.567 & 0.612 & 0.636 & 0.380 & 0.336 & 1.163 & 1.606 & 1.562 & 1.533 & 1.742 & 1.148 \\
\hline $\mathrm{Zr}$ & 0.003 & 0.007 & 0.007 & 0.007 & 0.003 & 0.021 & 0.085 & 0.255 & 0.238 & 0.244 & 0.269 & 0.006 \\
\hline
\end{tabular}


Table 21. Feed and glass compositions for the MVST glass sensitivity testing

\begin{tabular}{|c|c|c|c|c|c|c|}
\hline \multirow{2}{*}{ MVST-V no. } & \multicolumn{3}{|c|}{$\begin{array}{c}\text { Feed mix } \\
\text { (mass fraction) }\end{array}$} & \multicolumn{3}{|c|}{$\begin{array}{l}\text { Ternary glass compositions } \\
\text { (mass fraction) }\end{array}$} \\
\hline & $\mathrm{CaCO}_{3}$ & $\begin{array}{l}\text { Spiked dried } \\
\text { waste }\end{array}$ & $\mathrm{SiO}_{2}$ & $\begin{array}{l}\text { Alkaline } \\
\text { oxides }\end{array}$ & $\begin{array}{l}\text { Alkali } \\
\text { oxides }\end{array}$ & $\begin{array}{l}\text { Glass former } \\
\text { oxides }\end{array}$ \\
\hline $18^{\alpha}$ & 0.143 & 0.410 & 0.447 & 0.198 & 0.152 & 0.650 \\
\hline $19^{h}$ & 0.131 & 0.459 & 0.410 & 0.206 & 0.176 & 0.618 \\
\hline $20^{h}$ & 0.154 & 0.363 & 0.483 & 0.192 & 0.130 & 0.678 \\
\hline $21^{b}$ & 0.155 & 0.446 & 0.398 & 0.224 & 0.172 & 0.604 \\
\hline $22^{b}$ & 0.130 & 0.373 & 0.497 & 0.174 & 0.133 & 0.693 \\
\hline $23^{c}$ & 0.143 & 0.410 & 0.447 & 0.198 & 0.152 & 0.650 \\
\hline $24^{d}$ & 0.143 & 0.410 & 0.447 & 0.198 & 0.152 & 0.650 \\
\hline $25^{d}$ & 0.143 . & 0.410 & 0.447 & 0.198 & 0.152 & 0.650 \\
\hline
\end{tabular}

${ }^{a}$ Standard glass selected for sensitivity testing.

${ }^{b}$ One of the $\pm 10 \mathrm{wt} \%$ variations in the feed mix picked for sensitivity testing.

${ }^{c}$ Standard glass feed using the dried MVST surrogate sludge with maximum RCRA metals.

'Replicate of MVST-V18, the standard glass. 
Table 22. $\mathrm{Fe}^{2+} / \mathrm{Fe}^{3+}$ redox couple determinations for glass products of sensitivity testing

\begin{tabular}{|c|c|c|c|c|}
\hline Sample ID & $\mathrm{Fe}^{2+}$ & $\mathrm{Fe}$ total & $\mathrm{Fe}^{2+} / \mathrm{Fe}^{3+}$ & $\%$ reduced $\mathrm{Fe}$ \\
\hline \multirow[t]{2}{*}{ MVST-V-9 } & 0.007 & 0.028 & 0.33 & 25 \\
\hline & 0.007 & 0.029 & 0.32 & 24.1 \\
\hline \multirow[t]{2}{*}{ MVST-V-10 } & 0.004 & 0.021 & 0.24 & 19 \\
\hline & 0.007 & 0.026 & 0.37 & 26.9 \\
\hline \multirow[t]{2}{*}{ MVST-V-11 } & 0.005 & 0.022 & 0.29 & 22.7 \\
\hline & 0.013 & 0.041 & 0.46 & 31.7 \\
\hline \multirow[t]{2}{*}{ MVST-V-12 } & 0.012 & 0.046 & 0.35 & 26.1 \\
\hline & 0.016 & 0.061 & 0.36 & 26.2 \\
\hline \multirow[t]{2}{*}{ MVST-V-18 } & 0.002 & 0.014 & 0.2 & 14.3 \\
\hline & 0.001 & 0.015 & 0.08 & 6.7 \\
\hline \multirow[t]{2}{*}{ MVST-V-19 } & 0.002 & 0.015 & 0.18 & 13.3 \\
\hline & 0.003 & 0.017 & 0.27 & 17.6 \\
\hline \multirow[t]{2}{*}{ MVST-V-20 } & 0.001 & 0.012 & 0.1 & 8.3 \\
\hline & 0.002 & 0.015 & 0.18 & 13.3 \\
\hline \multirow[t]{2}{*}{ MVST-V-21 } & 0.001 & 0.013 & 0.09 & 7.7 \\
\hline & 0.002 & 0.016 & 0.17 & 15.5 \\
\hline \multirow[t]{2}{*}{ MVST-V-22 } & 0.004 & 0.02 & 0.33 & 20 \\
\hline & 0.006 & 0.023 & 0.54 & 26.1 \\
\hline \multirow[t]{2}{*}{ MVST-V-23 } & 0.003 & 0.018 & 0.25 & 16.7 \\
\hline & 0.004 & 0.02 & 0.33 & 20 \\
\hline \multirow[t]{2}{*}{ MVST-V-24 } & 0.006 & 0.025 & 0.46 & 24 \\
\hline & 0.006 & 0.027 & 0.4 & 22.2 \\
\hline \multirow[t]{2}{*}{ MVST-V-25 } & 0.004 & 0.022 & 0.28 & 18.2 \\
\hline & 0.006 & 0.027 & 0.4 & 22.2 \\
\hline
\end{tabular}


Table 23. Composition of the surrogate MVST sludge solids used in the glass sensitivity testing

\begin{tabular}{|c|c|c|}
\hline Compound & $\begin{array}{c}\text { Standard } \\
\text { (mass fraction) }\end{array}$ & $\begin{array}{l}\text { With maximum } \\
\text { RCRA metals } \\
\text { (mass fraction) }\end{array}$ \\
\hline \multicolumn{3}{|c|}{ RCRA metals } \\
\hline $\mathrm{Ag}_{2} \mathrm{O}$ & 0.000039 & 0.000099 \\
\hline $\mathrm{CdO}$ & 0.000048 & 0.000088 \\
\hline $\mathrm{Na}_{2} \mathrm{Cr}_{2} \mathrm{O}_{7}$ & 0.000524 & 0.000881 \\
\hline $\mathrm{HgCl}_{2}$ & 0.000082 & 0.000147 \\
\hline $\mathrm{PbO}$ & 0.000608 & 0.000930 \\
\hline $\mathrm{SeO}_{2}$ & 0.000135 & 0.000143 \\
\hline $\mathrm{TINO}_{3}$ & 0.000043 & 0.000048 \\
\hline \multicolumn{3}{|c|}{ Process metals } \\
\hline $\mathrm{Al}(\mathrm{OH})_{3}$ & 0.0203 & 0.0203 \\
\hline $\mathrm{CaCO}_{3}$ & 0.1367 & 0.1366 \\
\hline $\mathrm{Ca}(\mathrm{OH})_{2}$ & 0.0454 & 0.0454 \\
\hline $\mathrm{Fe}_{2} \mathrm{O}_{3}$ & 0.0041 & 0.0041 \\
\hline $\mathrm{KNO}_{3}$ & 0.0777 & 0.0777 \\
\hline $\mathrm{MgCO}_{3}$ & 0.0068 & 0.0067 \\
\hline $\mathrm{Mg}(\mathrm{OH})_{2}$ & 0.0374 & 0.0374 \\
\hline $\mathrm{NaNO}_{3}$ & 0.5727 & 0.5722 \\
\hline $\mathrm{NaCl}$ & 0.0089 & 0.0089 \\
\hline $\mathrm{NaF}$ & 0.0029 & 0.0029 \\
\hline $\mathrm{Na}_{2} \mathrm{SO}_{4}$ & 0.0056 & 0.0056 \\
\hline $\mathrm{Sr}\left(\mathrm{NO}_{3}\right)_{2}$ & 0.0008 & 0.0008 \\
\hline $\mathrm{Th}\left(\mathrm{NO}_{3}\right)_{4} \cdot 4 \mathrm{H}_{2} \mathrm{O}$ & 0.0290 & 0.0290 \\
\hline $\mathrm{UO}_{2}\left(\mathrm{NO}_{3}\right)_{2} \cdot 6 \mathrm{H}_{2} \mathrm{O}$ & 0.0502 & 0.0501 \\
\hline Total solids & 1.0000 & 1.0000 \\
\hline
\end{tabular}


Table 24. Glass bulk density and ratio of glass volume to wet sludge for the sensitivity testing

\begin{tabular}{ccc}
\hline Glass leach sample & $\begin{array}{c}\text { Calculated bulk } \\
\text { density } \\
(\mathrm{g} / \mathrm{mL})\end{array}$ & $\begin{array}{c}\text { Calculated } \\
\text { volume ratio of } \\
\text { glass/wet sludge }\end{array}$ \\
\hline MVST-V-18 & 2.80 & 0.42 \\
MVST-V-19 & 2.45 & 0.43 \\
MVST-V-20 & 2.50 & 0.54 \\
MVST-V-21 & 2.58 & 0.42 \\
MVST-V-22 & 2.57 & 0.50 \\
MVST-V-23 & 2.54 & 0.47 \\
MVST-V-24 & 2.51 & 0.47 \\
MVST-V-25 & 2.57 & 0.46 \\
\hline
\end{tabular}

"Bulk density calculated for leach samples assuming perfect right cylinders. With the slightly rounded tops, this includes some air volume at the top, in addition to the gas bubbles trapped inside the glass. 